EDUARDO GODINHO

\title{
A REGRA DA MAIORIA E A AUTONOMIA INDIVIDUAL: UM ESTUDO A PARTIR DE JOHN STUART MILL
}

\author{
Dissertação de Mestrado
}

Orientador: Prof. Celso Lafer

UNIVERSIDADE DE SÃO PAULO

Faculdade de Direito

São Paulo

2011 


\section{A REGRA DA MAIORIA E A AUTONOMIA INDIVIDUAL: UM ESTUDO A PARTIR DE JOHN STUART MILL}

Dissertação apresentada como requisito para a obtenção do título de Mestre em Filosofia e Teoria Geral do Direito pelo Programa de Pós-Graduação da Faculdade de Direito da Universidade de São Paulo, sob orientação do Prof. Titular Celso Lafer.

UNIVERSIDADE DE SÃO PAULO

Faculdade de Direito

São Paulo 
Banca Examinadora

Prof. Dr.

Instituição:

Assinatura:

Prof. Dr.

Instituição:

Assinatura:

Prof. Dr.

Instituição:

Assinatura: 


\section{RESUMO}

Este trabalho investiga as relações entre a regra da maioria e o princípio do dano de John Stuart Mill. Em suma, seu objetivo é descobrir de que maneira o princípio do dano funciona como um limite à regra da maioria. Diante disso, ao longo desta dissertação, examinam-se as dificuldades enfrentadas por Mill para conciliar utilitarismo e democracia, liberdade e razão. Este trabalho analisa, também, algumas ideias permanentemente presentes na reflexão histórica sobre o liberalismo: os conceitos de liberdade positiva e liberdade negativa; os diversos conceitos de paternalismo; e as muitas críticas dirigidas à regra da maioria.

Palavras-chave: regra da maioria - princípio do dano - John Stuart Mill - liberdade democracia - pluralismo - Iluminismo 


\begin{abstract}
This investigation studies the link between the majority rule and the harm principle by John Stuart Mill. To sum up, the purpose is to find out how the harm principle operates as a limit on majority rule. As a result, throughout this study, we examine the difficulties faced by Mill to reconcile utilitarianism and democracy, liberty and reason. This dissertation analyzes, still, some ideas that were constantly present in historical reflection about liberalism: the concept of the positive liberty and the concept of negative liberty; the various concepts of paternalism; and the many criticisms of the majority rule.
\end{abstract}

Keywords: majority rule - harm principle - John Stuart Mill - Liberty - democracy pluralism - Enlightenment 


\section{SUMÁRIO}

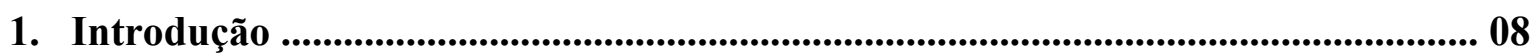

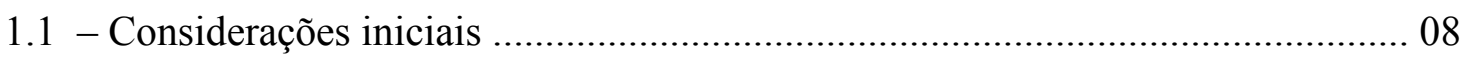

1.2 - O princípio do dano de John Stuart Mill ............................................................ 13

1.3 - Importância do tema e sua delimitação ……………………………………..... 16

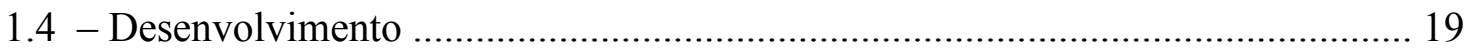

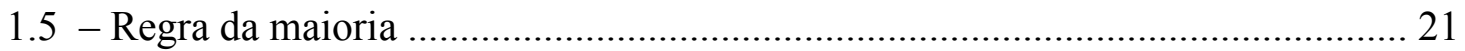

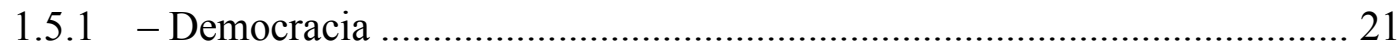

1.5.2 - Definição, falhas e limites …………………………………………... 21

1.5.3 - Regra da maioria e relativismo …………………………………….... 26

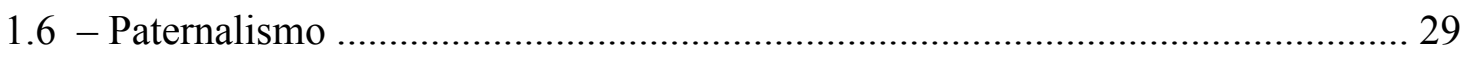

2. Liberalismo e democracia ……….................................................................................. 34

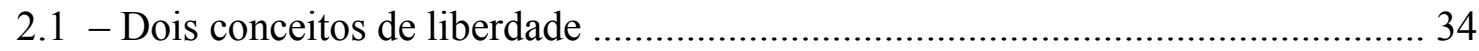

2.1.1 - Evolução do conceito de liberdade na filosofia ocidental ......................... 37

2.1.1.1 - Liberdade na antiguidade clássica grega ………………………. 37

2.1.1.2 - O livre-arbítrio ...................................................................... 39

2.1.1.3 - A liberdade moderna ................................................................. 42

2.1.2 - Limitação do poder …………………………………………………. 43

2.1.3 - As dificuldades do autogoverno …………………………………........ 46

2.1.4 - Democracia e liberalismo: origem no individualismo .............................. 48

2.1.5 - Regra da maioria: uma norma secundária ……………………………... 49

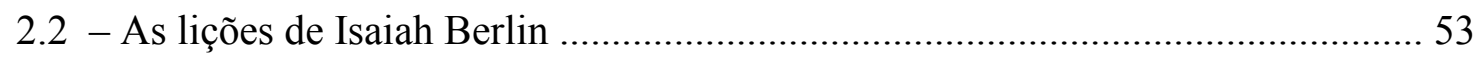

2.2.1 - A liberdade negativa …………………………………………...... 54

2.2.1.1 - Individualismo e liberdade ..................................................... 55

2.2.1.2 - Liberdade negativa e democracia …………………………….... 56

2.2.2 - Dimensão positiva da liberdade ………………………………………. 57

2.2.2.1 - Metáfora do autodomínio ............................................................ 57

2.2.2.2 - A luta contra os desejos .............................................................. 59

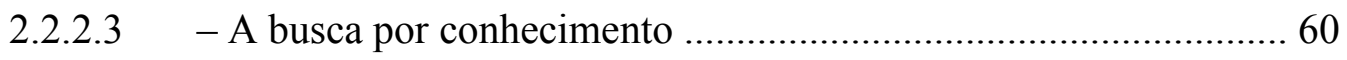

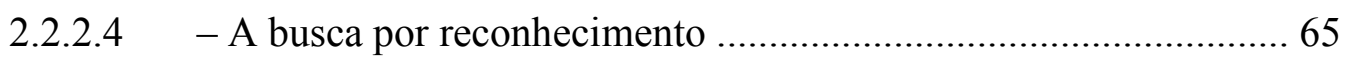

2.2.3 - O velho problema da vontade livre ..................................................... 66

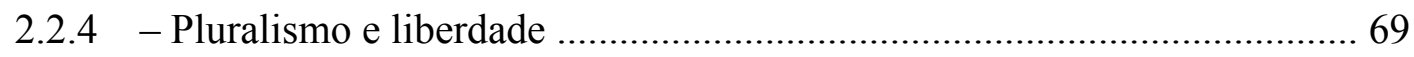




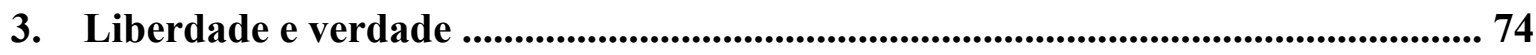

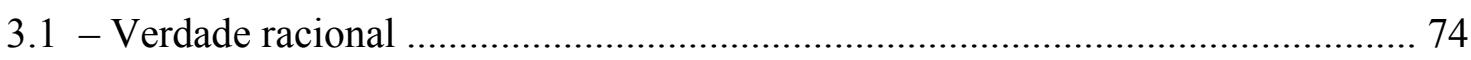

3.2 - O Iluminismo: a centralidade da ciência e dos direitos individuais .................... 75

3.2.1 - Os adversários do Iluminismo .......................................................... 77

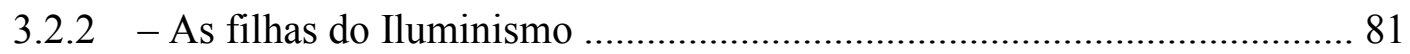

3.3 - A teoria de John Stuart Mill ................................................................. 83

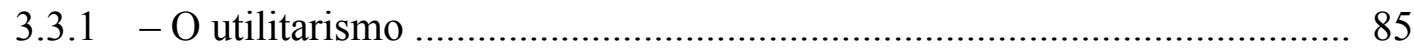

3.3.2 - O papel do dano na legitimação estatal ............................................... 88

3.3.3 - Aplicação do princípio do dano ............................................................ 90

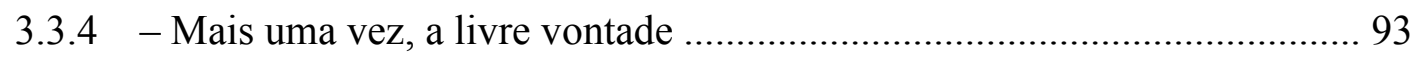

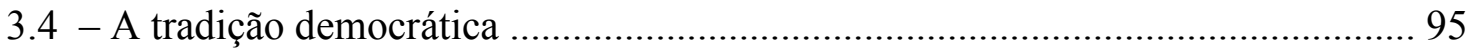

3.5 - A democracia em John Stuart Mill .................................................................. 96

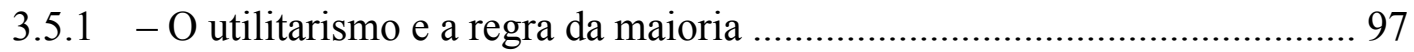

3.6 - O princípio do dano e a regra da maioria ....................................................... 101

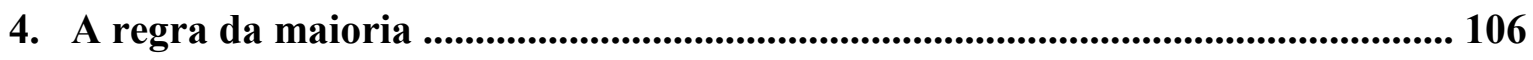

4.1 - Por que devemos lealdade ao princípio majoritário? ...................................... 106

4.2 Argumentos axiológicos e técnicos: o estudo de Norberto Bobbio ..................... 107

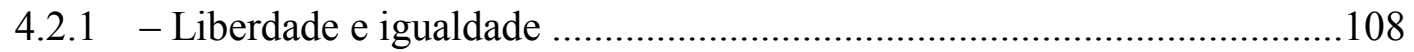

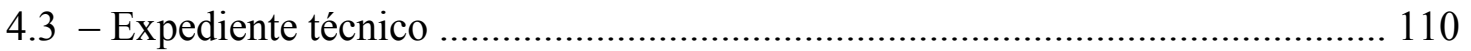

4.4 - Jeremy Waldron: A dignidade do princípio majoritário ................................. 111

4.4.1 - A física do consentimento ............................................................... 112

4.4.1.1 - As circunstâncias da política ................................................ 116

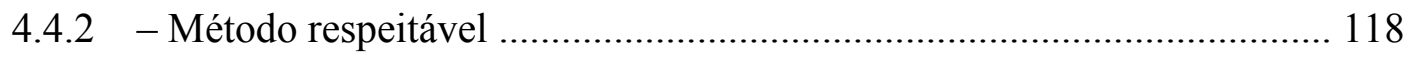

4.4.2.1 - A arbitrariedade ................................................................. 121

4.4.2.2 - A "tirania da maioria" .............................................................. 123

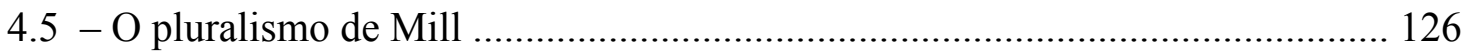

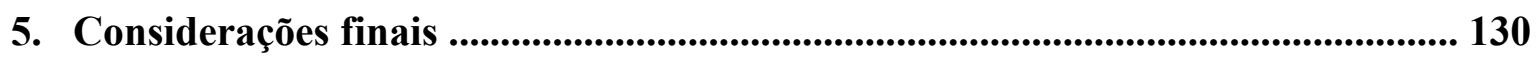

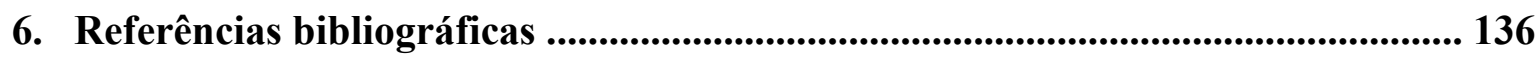




\section{CAPÍTULO I - INTRODUÇÃO}

[Preceito] 175 Aceitar a decisão da maioria

Por esse preceito somos ordenados a seguir a maioria caso haja uma diferença de opinião entre os sábios com relação a qualquer uma das leis da Torá.

(Maimônides) ${ }^{1}$

\section{1 - Considerações iniciais}

É curioso que, para uma religião tão antiga quanto o judaísmo, entre os preceitos que o próprio Deus estabeleceu, esteja incluído o dever de seguir a decisão da maioria. Afinal, nas religiões, as pessoas procuram respostas firmes para as questões mais profundas de suas vidas e é engraçado imaginar que a contagem de cabeças seja, em alguns casos, um procedimento útil nessa busca.

O fato, porém, é que a regra da maioria - também chamada de princípio majoritário - tem, desde há muito, um vasto campo de aplicação. Nos tribunais, quando os magistrados lavram seus acórdãos; nos prédios residenciais, quando os condôminos se reúnem para deliberar; nos Estados democráticos, quando os representantes do povo votam suas leis: em todos esses foros, as decisões se dão com base nessa regra ${ }^{2}$. Mas é neste último caso - o regime democrático - que a regra da maioria ganha privilegiada atenção. Muitas das críticas dirigidas à democracia são, na verdade, críticas à regra da maioria. Seguem essa linha acusações frequentes, como a de que a democracia é incapaz de

\footnotetext{
${ }^{1}$ MAIMON, Moisés Bem. O livro dos mandamentos: 248 preceitos positivos. Traduzido por Giuseppe Nahaïssi. São Paulo: Hedra, 2007, p. 254.

${ }^{2}$ CAMPILONGO, Celso Fernandes. Direito e Democracia. 2. ed. Editora Max Limonad, 2000, pp. 27-28.
} 
proteger direitos fundamentais, ou de que a democracia propicia o risco de uma tirania da maioria, ou de que as leis democraticamente produzidas são eivadas de uma irracionalidade patente. Essas não são, evidentemente, denúncias contra as exigências democráticas de ampla participação dos cidadãos no processo decisório e de votos com igual peso. São, na verdade, críticas ao genuíno procedimento que faz prevalecer, de maneira impositiva, a proposta com maior número de votos.

Não é difícil entender o que motiva tais críticas. O princípio majoritário, às vezes, parece arbitrário: projetos de lei revestem-se de autoridade jurídica com nada mais do que números ao seu lado. Às vezes, parece irracional: a ausência casual de uma pessoa no dia da votação pode ser decisiva para aprovação de uma lei com profundos impactos para a sociedade. Outras vezes, o ato de contar votos assemelha-se mais ao ato de tirar cara e coroa do que a exercícios de reflexão e ponderação racional. Como se pode levar a sério a legislação produzida dessa maneira? ${ }^{3}$

Não por outro motivo, filósofos do direito e da política olham com desconfiança para a regra da maioria. Os primeiros, mal falam dela quando tratam da mais comum fonte do direito em nossa tradição: a lei. Os últimos, admitem que o recurso à regra da maioria é inevitável, mas ressalvam: ela não pode ser usada em quaisquer circunstâncias. Não por acaso, nos últimos tempos, o estudo sobre o princípio majoritário tem-se apresentado, também, quase sempre, como um estudo sobre seus limites.

Por outro lado, o modo como, ao longo de sua história, o pensamento político contrapôs democracia a liberalismo, demonstra bem a força das críticas ao princípio majoritário. Porque, quando se fala de valores desprotegidos pela democracia (ou pelo princípio majoritário), o exemplo, por excelência, é a liberdade: não foram poucas as vezes em que se denunciou a inaptidão da democracia para proteger os ideais liberais ou mesmo a sua tendência destrutiva em relação à liberdade.

Por permitir a ampla participação no processo decisório, a democracia foi muitas vezes considerada uma promissora fonte de conquistas em prol da liberdade. Embora não discordassem disso, alguns pensadores liberais continuaram insistindo na necessidade de se limitar o poder do Estado sobre os homens, ainda quando esse poder

\footnotetext{
${ }^{3}$ WALDRON, Jeremy. A Dignidade da Legislação. Traduzido por Luís Carlos Borges. São Paulo: Martins Fontes, 2003, p. 155.
} 
fosse exercido pelo povo. Pois, para esses pensadores, estava em jogo não o que a democracia e seu princípio majoritário haviam feito pela liberdade, mas o que haviam deixado de fazer.

Veja-se o caso do artigo 1.641, do Código Civil brasileiro. A norma contida nesse artigo estabelece que o indivíduo maior de setenta anos não pode escolher o regime de bens de seu casamento: deve casar-se, obrigatoriamente, sob o regime da separação de bens $^{4}$. Sua justificativa mais aparente, normalmente encontrada em manuais de Direito Civil, está em proteger o indivíduo septuagenário contra o risco patrimonial de se envolver com uma pessoa mais jovem, interessada, tão-somente, em apropriar-se de seus bens ${ }^{5}$. Uma vez, porém, que as pessoas, em regra, são livres para escolher o regime de bens de seu próprio casamento, não nos causaria admiração se alguns septuagenários se sentissem ultrajados com essa norma, por entenderem que ela lhes subtrai parte considerável de sua liberdade (autonomia), estabelecendo a presunção absoluta de sua incapacidade para escolher os próprios relacionamentos.

Com efeito, estamos acostumados a observar o surgimento de normas jurídicas produzidas segundo o princípio majoritário. Muitas delas restringem a liberdade das pessoas, impondo-lhes deveres e proibindo-lhes determinadas condutas. Assim, leis são promulgadas para proibir o fumo em lugares de uso coletivo, para exigir que pessoas submetam seus automóveis a uma inspeção compulsória, para tornar obrigatória a identificação de pessoas em aeroportos etc. Em todos esses casos, as restrições impostas podem ser justificadas como artifícios necessários a permitir a coexistência das liberdades individuais - argumento de resto usado, ainda que implicitamente, em quase todas as teorias que fundamentam a existência dos Estados.

No entanto, quando a liberdade do indivíduo é limitada com a mera finalidade de protegê-lo de suas próprias ações ou com o propósito de proporcionar-lhe

\footnotetext{
${ }^{4}$ A Lei Ordinária $\mathrm{n}^{\circ}$ 12.344, de 09 de dezembro de 2010, alterou o disposto no artigo 1.641, inciso II, Código Civil, dando-lhe a seguinte redação: "É obrigatório o regime da separação de bens no casamento: II - da pessoa maior de 70 (setenta) anos". Até o advento dessa lei, o Código Civil estabelecia essa obrigatoriedade para os maiores de 60 (sessenta) anos. O presente estudo foi inicialmente desenvolvido, levando-se em conta a redação antiga. No entanto, consideramos que o acréscimo de dez anos à idade limite não altera qualquer das considerações aqui formuladas acerca da motivação paternalista que, aparentemente, sustenta esse dispositivo.

${ }^{5}$ Sobre essa justificativa, ainda tendo em conta a redação antiga do referido dispositivo, vejam-se, entre muitos outros, DINIZ, Maria Helena. Curso de direito civil brasileiro, $5^{\circ}$ volume: direito de família. 20. ed. São Paulo: Saraiva, 2005, pp. 187-188 e VENOSA, Silvio de Salvo. Código Civil interpretado. São Paulo: Atlas, 2010, pp. 1510-1511.
} 
bem estar, estamos diante de uma intervenção de caráter paternalista: um tipo de intervenção que, em alguns casos - e o exemplo do artigo 1.641, do Código Civil brasileiro, é paradigmático -, parece tratar as pessoas como menos capazes do que realmente são.

Assim, além da pergunta que é logicamente precedente - por que devemos obedecer à vontade da maioria? -, as intervenções paternalistas nos colocam diante de outra questão: O que justifica que a opinião majoritária imponha uma restrição paternalista à liberdade dos indivíduos? Trata-se de duas questões difíceis, com as quais os filósofos da política vêm se ocupando há tempos. Embora sejam estas as duas questões centrais que guiam o presente estudo, a presente dissertação não buscará respondê-las.

A propósito, um pensador inglês do século XIX, chamado John Stuart Mill, buscou oferecer uma resposta à segunda das duas questões ora formuladas. Num famoso ensaio, afirmou que um homem não pode ser compelido a fazer ou omitir algo por razões paternalistas. Segundo ele, intervenções paternalistas são sempre ilegítimas; não há razão que as possa justificar. Mill fundamentou sua resposta em um princípio - conhecido como princípio do dano - que, segundo acreditava, possibilitaria distinguir as interferências legítimas das ilegítimas. Desde sua publicação, muitos críticos têm apontado deficiências nos critérios estipulados nesse princípio. Não obstante, a contribuição do pensamento de Mill para esse tema é tão relevante que seu célebre princípio nunca deixou de ser revisitado e continuamente refletido por todos quantos se aventuraram a procurar os limites da intervenção estatal na autonomia individual.

Por isso, levando-se em conta as duas questões que guiam o presente estudo - e, tomando-se como ponto de partida as controvérsias em torno do princípio enunciado por John Stuart Mill -, o objetivo desta dissertação é responder à seguinte pergunta: De que maneira o princípio do dano é apto a estabelecer, numa democracia, limites ao poder exercido com base na regra da maioria?

O que se propõe aqui é perseguir esse objetivo, lançando-se mão da contribuição de quatro notáveis autores que também revisitaram o princípio do dano formulado por John Stuart Mill.

O primeiro deles - e, talvez, o que mais contribuiu para o desenvolvimento do presente trabalho - é Norberto Bobbio. Notável professor da Universidade de Turim e 
autor de preciosos trabalhos de filosofia jurídica e política, Bobbio nos revela, em alguns de seus mais importantes escritos, o anseio de Mill por compatibilizar duas dimensões de um mesmo valor: a liberdade. Como estudioso da regra da maioria e autêntico defensor da liberdade individual, Bobbio nos oferece, em sua obra, relevantes pistas sobre o papel que o princípio majoritário exerce nessa tarefa de conjugar os ideais democráticos com os princípios liberais.

O segundo é Isaiah Berlin. Defensor do pluralismo e renomado professor de história das ideias políticas de Oxford, Sir Isaiah Berlin nos oferece uma visão diferente acerca das relações entre liberalismo e democracia. Com sua aparente desconfiança ante o método democrático, ele apresenta a liberdade como um bem de valor indiscutível, num mundo em que a resposta para os genuínos problemas da humanidade é inalcançável. Ao longo desse trabalho, veremos como Berlin parece denunciar os perigos que o princípio majoritário apresenta à liberdade.

O terceiro é Ian Shapiro, cientista político contemporâneo que realizou uma exposição crítica do princípio milliano. Segundo ele, as principais teorias modernas de justificação política - e entre elas está o princípio do dano - são tributárias do Iluminismo e, por isso, esbarram no mesmo problema tipicamente iluminista: a dificuldade de se conciliar a busca pela verdade racional - e o decorrente apego à ciência - com a defesa da liberdade humana e dos direitos fundamentais que a protegem. A intenção de Shapiro é mostrar que o difícil convívio entre essas preocupações iluministas é mais bem administrado pelas propostas da tradição democrática.

Por fim, o presente trabalho contará com os fortes argumentos de Jeremy Waldron em favor do princípio majoritário. São refutadas por Waldron as históricas acusações de que esse princípio é alheio à razão e hostil às liberdades individuais. Veremos que esse autor apresenta o princípio majoritário como um procedimento digno, cuja importância provém de sua aptidão a respeitar o ideal de pluralismo. Para o ideal do pluralismo, tanto a falibilidade humana, quanto os desacordos profundos que as pessoas têm acerca da verdade e da justiça, são apenas frutos da espontaneidade e da liberdade que as tornam humanas. 
Uma vez que é evidente a importância central do princípio do dano para o presente estudo, nada mais apropriado do que iniciarmos com uma breve apresentação de sua fórmula.

\section{2 - O princípio do dano de John Stuart Mill}

A Nelson Mandela e Mahatma Ghandi, a história concedeu o papel de heróis morais, porque eles enfrentaram autoridades políticas injustas. Adolph Eichmann, bem ao contrário, por sua lealdade a leis injustas, obteve inequivocamente o papel de vilão moral. As histórias desses homens - tal como o dilema de Antígona - sugerem-nos que a autoridade de qualquer governo deixa de ser legítima quando ele não observa determinados limites. Nenhum desses casos, porém, nos diz clara e objetivamente quais são esses limites. Fica então a pergunta: Há algum meio de se saber quando os governos são dignos de nossa lealdade ${ }^{6}$ ?

A tradição democrática parece oferecer uma resposta a essa questão. No que ela tem de mais essencial - e nesse ponto recorro aos escritos de Ian Shapiro -, essa tradição postula que são legítimas as decisões governamentais, quando os indivíduos afetados por elas "participam adequadamente de sua elaboração" e têm "significativas oportunidades de se opor ao governo do momento"7. Em seu ensaio A liberdade, John Stuart Mill também oferece um tipo de resposta àquela indagação: segundo ele, são legítimas somente as decisões governamentais que observam o princípio do dano.

Se, em seu tempo, o inglês John Stuart Mill houvesse conhecido um dispositivo legal como o artigo 1.641, do Código Civil brasileiro, certamente o teria rejeitado como injusto. Mill, um filósofo do século XIX, tornou-se célebre, entre outras razões, pela ardorosa defesa da liberdade individual, professada no ensaio $A$ liberdade, cuja proteção definitiva ele buscou ao elaborar seu famoso princípio do dano. Trata-se de um princípio que Mill considerava muito simples:

\footnotetext{
${ }^{6}$ SHAPIRO, Ian. Os fundamentos morais da política. Traduzido por Fernando Santos. São Paulo: Martins Fontes, 2006, p. 3.

${ }^{7}$ SHAPIRO, Ian. Os fundamentos morais da politica. Op. cit., pp. 7-8.
} 
Esse princípio é o de que a autoproteção constitui a única finalidade pela qual se garante à humanidade, individual ou coletivamente, interferir na liberdade de ação de qualquer um. O único propósito de se exercer legitimamente o poder sobre qualquer membro de uma comunidade civilizada, contra sua vontade, é evitar danos aos demais. Seu próprio bem, físico ou moral, não é garantia suficiente. Não pode ser legitimamente compelido a fazer ou deixar de fazer por ser melhor para ele, porque o fará feliz, porque, na opinião dos outros, fazê-lo seria sábio, ou mesmo acertado ${ }^{8}$.

Não se pode negar a atração exercida por esse princípio. Já num primeiro momento, a abordagem que Mill assume nessa obra conquista o leitor por sua aparente simplicidade e pela postura de quem se coloca decisivamente ao lado da liberdade 9 . John Stuart Mill era, ao mesmo tempo, um liberal e um democrata. Postava-se a favor do governo popular, mas estava ciente de que era importante limitar o poder do governo sobre o indivíduo, mesmo quando esse governo fosse controlado pelo povo. Por isso, enunciou um princípio que, segundo acreditava, poderia delinear de maneira definitiva os limites para a "interferência legítima da opinião coletiva sobre a independência individual"10.

Não há dúvida de que a intenção de John Stuart Mill era proteger a liberdade individual contra medidas paternalistas, o que fica bem claro quando ele repudia o constrangimento que se realiza em nome do bem estar do sujeito constrangido. Mas também fica claro, já no início de seu ensaio, que lhe interessava igualmente proteger a liberdade daquilo que - sob a influência de Tocqueville - ele chamou "tirania da maioria": a opressão infligida pela opinião pública majoritária ${ }^{11}$. Ou seja, o princípio do dano visava à defesa da liberdade, tanto em face do paternalismo estatal, quanto em face do poder abusivo que pudesse ser exercido pela maioria.

\footnotetext{
${ }^{8}$ MILL, John Stuart. A liberdade / Utilitarismo. Traduzido por Eunice Ostrensky. São Paulo: Martins Fontes, 2000, p. 17. No original: "That principle is that the sole end for which mankind are warranted, individually or collectively, in interfering with the liberty of action of any of their number, is self protection. That the only purpose for which power can be rightfully exercised over any member of a civilized community, against his will, is to prevent harm to others. His own good, either physical or moral, is not a sufficient warrant. He cannot rightfully be compelled to do or forbear because it will be better for him to do so, because it will make him happier, because, in the opinion of the others, to do so would be wise, or even right". MILL, John Stuart. Utilitarianism, Liberty and Representative Government. Londres: J. M. Dent \& Sons Ltd., 1910, pp. 72-73.

${ }^{9}$ A esse respeito, veja-se: SHAPIRO, Ian. Os fundamentos morais da política. Op. cit., p. 71.

${ }^{10}$ MILL, John Stuart. A liberdade / Utilitarismo. Traduzido por Eunice Ostrensky. São Paulo: Martins Fontes, 2000, p. 11.

${ }^{11}$ MILL, John Stuart. A liberdade / Utilitarismo. Op. cit., pp. 09-11. TOCQUEVILLE, Alexis de. A Democracia na América. Traduzido por Neil Ribeiro da Silva. Belo Horizonte: Editora Itatiaia; São Paulo: Edusp, 1987, p. 190.
} 
No entanto - já o dissemos - logo se verifica que o princípio do dano não é nada simples ${ }^{12}$. Embora ele se baseie, essencialmente, na distinção entre ações que afetam apenas ao próprio agente e ações que prejudicam a terceiros, seu argumento não oferece critérios para discernir entre umas e outras. Nas palavras de Isaiah Berlin, "virtualmente todos os críticos de Mill têm apontado que tudo o que faço pode ter resultados prejudiciais a outros seres humanos" ${ }^{\prime 13}$. Por isso, não é tarefa fácil - e alguns consideram infactível discernir entre aquilo que pertence exclusivamente à esfera privada do indivíduo e o que é pertinente à esfera pública.

Não obstante - e repetindo os ensinamentos de Celso Lafer -, a distinção traçada por Stuart Mill "tem um valor heurístico, na medida em que ajuda a perceber diferenças. No caso, as diferenças que a dicotomia milliana ajuda a esclarecer não estão tanto nas condutas, mas nas razões que justificam ou invalidam a intervenção da sociedade" ${ }^{\prime 14}$. Em outras palavras, ela nos indica que, se uma intervenção da sociedade na liberdade individual estiver lastreada em razões outras que não a prevenção de danos a terceiros, há bons motivos para considerar tal intervenção injusta. Daí porque crermos que a forma mais lúcida de se estudar o tema é fazê-lo a partir do pensamento de John Stuart Mill.

Ademais, a grande influência exercida pelo ensaio sobre $A$ liberdade também se deve às distintas leituras e permanentes questões que ele tem suscitado desde sua publicação ${ }^{15}$. Desde então, dificilmente tem sido possível discutir o tema sem a colocação das seguintes questões: Como determinar que condutas não afetam a terceiros? Pode haver intervenções justas, ainda que paternalistas? ${ }^{16}$ De outro giro, a obra de Stuart

\footnotetext{
${ }^{12}$ Segundo Alan Ryan, "Commentators have complained about Mill's appeal to one very simple principle; they have said that little in human life is simple, and the question of when to interfere with each other's liberty is not part of that little". RYAN, Alan. "Mill in a liberal landscape". In: SKORUPSKI, John (organizador). The Cambridge companion to Mill. Nova York: Cambridge University Press, 1998, p 499.

13 BERLIN, Isaiah. Estudos sobre a humanidade: uma antologia de ensaios. Traduzido por Rosana Eichenberg; edição de Henry Hardy e Roger Hausheer. São Paulo: Companhia das Letras, 2002, p. 257.

${ }^{14}$ LAFER, Celso. Ensaios Liberais. São Paulo: Siciliano, 1991, p. 72.

${ }^{15}$ Como salienta Celso Lafer, o ensaio sobre $A$ Liberdade ostenta características que o colocam na condição de um clássico, porque ele é: " 1 . altamente representativo e esclarecedor da doutrina liberal do século XIX (...); 2. vem suscitando até hoje, pela sua atualidade, distintas leituras, sendo o autor visto ora como conservador, ora como antecipador da convergência progressista de liberalismo e socialismo; 3. deu uma contribuição a uma sempre difícil teoria modelar da liberdade, que merece ser permanentemente ouvida e meditada". LAFER, Celso. Ensaios Liberais. São Paulo: Siciliano, 1991, p. 62.

${ }^{16}$ Os principais pensadores que contemporaneamente estudam o tema do paternalismo embrenham-se em tais questões: DWORKIN, Gerald. "Paternalism". In: SCHAUER, Frederick e SINNOTT-ARMSTRONG, Walter (organizadores). The philosophy of law: classic and contemporary readings with commentary. New
} 
Mill tem se prestado a indagações sobre sua própria coerência: Como é possível conciliar a defesa do governo popular com seu apego à liberdade individual? Como é possível conciliar a defesa do pluralismo com o dogmatismo que a teoria utilitarista implica? E como compatibilizar o universalismo moral, proposto no utilitarismo, com o relativismo encarnado na defesa dos instrumentos democráticos? Apesar das notórias dificuldades, parece-nos que é em sua capacidade de defender esses ideais aparentemente irreconciliáveis que está a grande contribuição de John Stuart Mill para o pensamento contemporâneo, o que desponta como mais uma relevante razão para lançar mão de suas reflexões.

\section{3 - Importância do tema e sua delimitação}

Há duas razões para se considerar relevante o objeto deste estudo.

A primeira é a sempre atual dificuldade para se discernir entre medidas protecionistas geralmente aceitas - como as destinadas à proteção dos incapazes - e práticas paternalistas condenáveis. Essa dificuldade - especialmente marcante na obra de John Stuart Mill - é ainda sentida em nossos dias, sempre que nos defrontamos com normas como a do artigo 1.641, do Código Civil brasileiro. Basta um rápido olhar para se constatar que há hoje, no Brasil, uma grande quantidade de intervenções estatais cuja legitimidade é posta em dúvida, precisamente pelo grau do paternalismo a elas subjacente.

É o caso da Lei ${ }^{\circ}$ 13.541, de 07 de maio de 2009, promulgada no Estado de São Paulo com a finalidade de proibir o consumo de produtos fumígenos em ambientes de uso coletivo. Essa lei colocou em primeiro plano a discussão sobre o limite entre ações que constituem meras restrições à liberdade de fumar e ações que causam seu completo aniquilamento. É o caso, também, de pacientes que recusam um tratamento médico, a despeito do iminente risco de morte que eles correm: circunstância em que a indisponibilidade da vida se contrapõe à autonomia individual, a exemplo do que ocorre com pacientes Testemunhas de Jeová, que não aceitam a transfusão sanguínea.

York: Oxford University Press, 1996, pp. 331-337 e FEINBERG, Joel. Filosofia social. Traduzido por Alzira Soares da Rocha e Helena Maria Camacho. Rio de Janeiro: Zahar Editores, 1974. 
O que há em comum nesses casos - dos quais poderíamos citar mais exemplos (o uso obrigatório de cinto de segurança em automóveis ou a contribuição compulsória à previdência social, entre outros) - é o patente paternalismo que os motiva. Por isso, demandam uma pesquisa mais cuidadosa sobre os limites do direito produzido segundo o princípio majoritário.

Dessa demanda, surge a segunda razão para a relevância do tema: a escassa produção literária a respeito do princípio majoritário. Até onde se pôde aferir, há, no Brasil, apenas uma monografia de peso sobre o tema da regra da maioria. Trata-se da obra Direito e Democracia, que Celso Fernandes Campilongo escreveu como tese de doutoramento. Nesse trabalho, aliás, o autor também menciona a escassez de monografias publicadas sobre o tema nas três últimas décadas do século $\mathrm{XX}^{17}$. Dentre as poucas referências destacam-se o trabalho de Claude Leclercq, Le principe de la majorité (1971); o de Elaine Spitz, Majority rule (1984); e a obra de Edoardo Ruffini sobre a história da regra da maioria, Il principio maggioritario: profilo storico $(1976)^{18}$.

Além disso, em sua obra, A dignidade da legislação, Jeremy Waldron recorda que os autores clássicos da nossa tradição filosófica muito pouco disseram sobre a regra da maioria. De fato, dentre os que são considerados os grandes teóricos do Estado, Aristóteles e Hobbes escreveram algumas poucas linhas sobre o princípio majoritário, Locke deteve-se nele por, no máximo, uma página e Rousseau dispensou-lhe vagos comentários dispersos ao longo de sua mais importante obra de justificação do Estado ${ }^{19}$. Por que, indaga Waldron, um expediente usado em tão larga escala e, no mínimo, tão antigo quanto a democracia ateniense, foi tão subteorizado pelos clássicos da ciência política? ${ }^{20}$ Começa daí o interesse em se estudar a regra da maioria, sua justificação e seus limites. Seria o princípio majoritário "óbvio demais para exigir qualquer gasto de energia

${ }^{17}$ CAMPILONGO, Celso Fernandes. Direito e Democracia. 2. ed. Editora Max Limonad, 2000, p. 36.

${ }^{18}$ LECLERCQ, Claude. Le principe de la majorité. Paris: Librairie Armand Colin, 1971; SPITZ, Elaine. Majority rule. Chatham: Chatham House Publishers, 1984 e RUFFINI, Edoardo. Il principio maggioritario: profilo storico. Milão: Adelphi Edizioni S.P.A., 1976.

${ }^{19}$ ARISTÓTELES. A Politica. Traduzido por Roberto Leal Ferreira. 2. ed. São Paulo: Martins Fontes, 1998 (Clássicos), pp. 171-172; HOBBES, Thomas. Leviatã ou Matéria, forma e poder de um estado eclesiástico e civil. Organizado por Richard Tuck; traduzido por João Paulo Monteiro e Maria Beatriz Nizza da Silva; tradução revisada por Eunice Ostrensky. São Paulo: Martins Fontes, 2008 (Clássicos Cambridge de filosofia política), pp. 141-142; LOCKE, John. Dois Tratados sobre o Governo. Traduzido por Julio Fischer; rev. técnica de Renato Janine Ribeiro. São Paulo: Martins Fontes, 2005, pp. 468-472; ROUSSEAU, Jean-Jacques. Do contrato social: princípios de direito político. Traduzido por José Cretella Jr. e Agnes Cretella. 2. ed. rev. da tradução. São Paulo: Editora Revista dos Tribunais, 2008, livro I, cap. 5 e livro IV, cap. 2.

${ }^{20}$ WALDRON, Jeremy. A dignidade da legislação. Traduzido por Luís Carlos Borges. São Paulo: Martins Fontes, 2003, pp. 151-152. 
filosófica?"21 . Não parece que seja o caso. De todo modo, porém, é preciso refletir se não seria papel da filosofia discutir justamente sobre aquilo que parece óbvio aos olhares superficiais do senso comum ${ }^{22}$.

Muito embora tenhamos reduzido o objeto deste estudo a uma pergunta bastante pontual, cuja resposta investigaremos amparados na obra de autores específicos, convém - e aqui seguimos o conselho de Michael Walzer ${ }^{23}$ - explicar melhor aquilo que não se pretende fazer no presente estudo.

Em primeiro lugar, cumpre recordar que, no presente estudo, a atenção está voltada às intervenções de caráter paternalista. Isso exclui de seu campo de análise outras formas bastante comuns de intervenção estatal, como as intervenções que buscam a distribuição de renda ou a socialização de recursos entre os membros da sociedade. Essa exclusão evita que adentremos o histórico debate que opõe o valor da igualdade entre os homens ao valor da liberdade individual: um debate complexo no qual está em jogo, ainda uma vez, a busca por uma resposta definitiva acerca do papel do Estado na vida das sociedades.

Depois, não se pretende, aqui, empreender uma detalhada exposição sobre as teorias que buscam justificar o paternalismo estatal. Entendemos suficiente, para os fins deste estudo, a simples constatação de que há muitas e díspares teorias para sua justificação - as quais divergem até quanto ao que são intervenções paternalistas.

Ademais, cumpre dizer que não está entre os objetivos deste estudo examinar o papel das cláusulas pétreas constitucionais como limites ao princípio majoritário. Esse exame está na ordem do dia e tem sido objeto de uma discussão calorosa sobre se as constituições devem conter uma lista de direitos irrevogáveis ou se os cidadãos devem ter o poder de alterar quaisquer direitos por meio da regra da maioria. Como nossa indagação refere-se tão somente ao paternalismo estatal enquanto limite àquela regra, essa discussão somente terá interesse na medida em que contribua para o desfazimento das

\footnotetext{
${ }^{21}$ WALDRON, Jeremy. A dignidade da legislação. Op. cit., p. 153.

22 “A 'obviedade' de um princípio (...) é uma indicação da sua posição central no esquema conceitual que estrutura nossa prática”, em WALDRON, Jeremy. A dignidade da legislação. Op. cit., p. 154.

${ }^{23}$ WALZER, Michael. Da Tolerância. Traduzido por Almiro Pisetta. São Paulo: Martins Fontes, 1999, p. 13.
} 
dúvidas relacionadas à justificação do princípio majoritário e a sua relação com o princípio milliano ${ }^{24}$.

Por fim, embora esta dissertação perfaça uma longa reflexão sobre a compatibilidade dos processos democráticos com as liberdades individuais, ela não inclui um debate adequado sobre a democracia representativa. Entendemos, como Jeremy Waldron, que a representação reduz a deliberação e a votação a uma escala menor, politicamente manejável: trata-se, pois, de uma forma de se respeitar a grande magnitude das cidadanias modernas ${ }^{25}$.

\section{4 - Desenvolvimento}

O desenvolvimento deste trabalho atende a tais limitações e seguirá a ordem que descrevemos a seguir.

Este primeiro capítulo, além de oferecer um esboço do estudo empreendido, propõe-se também a discutir, em linhas gerais, o sentido de conceitos utilizados constantemente ao longo deste trabalho. Assim, ainda neste capítulo introdutório, teremos uma breve exposição sobre o conceito de paternalismo estatal e sobre aspectos relevantes daquilo que chamamos regra da maioria. Observaremos como a regra da maioria é considerada condição indispensável para a existência de uma democracia e apontaremos as principais críticas que lhe são dirigidas. Veremos, também, a respeito do paternalismo estatal, que, apesar de importantes teorias que buscam justificar-lhe a existência, nenhuma delas mostrou-se hábil para delinear, de maneira objetiva, seus limites ou para dirimir os sérios conflitos verificados em cada caso concreto.

\footnotetext{
${ }^{24}$ Jeremy Waldron, um dos principais autores estudados neste trabalho, é também um dos protagonistas deste debate, juntamente com Ronald Dworkin. Waldron está entre os que se opõem às cartas rígidas de direitos constitucionais, apontando-as como anti-democráticas. Dworkin, de seu lado, defende a existência de direitos inalteráveis e a conveniência de um controle judicial com a última palavra sobre a violação de tais direitos. Ambos os autores dedicaram várias obras para a defesa de seus pontos de vista. Remetemos o leitor a dois artigos, emblemáticos dessa disputa porque reunidos na mesma obra: DWORKIN, Ronald. "The Moral Reading and the Majoritarian Premise" e WALDRON, Jeremy. "Deliberation, Disagreement, and Voting", ambos publicados em KOH, Harold H. e SLYE, Ronald C. (organizadores). Deliberative democracy and human rights. New Haven e Londres: Yale University Press, 1999. Para um resumo dessa discussão e de seus aspectos mais relevantes, há uma excelente obra: MENDES, Conrado Hübner. Controle de Constitucionalidade e Democracia. Rio de Janeiro: Elsevier, 2008. Ver também: NOVAIS, Jorge Reis. Direitos fundamentais: trunfos contra a maioria. Coimbra: Coimbra Editora, 2006, especialmente em seu Capítulo I.

${ }^{25}$ WALDRON, Jeremy. Derecho y desacuerdos. Op.cit., 133.
} 
No segundo capítulo, iniciaremos um debate sobre as relações entre liberalismo e democracia. Dois conceitos distintos de liberdade - que aqui chamamos conceito liberal e conceito democrático - servem de mote para uma reflexão em torno de importantes indagações: A democracia mostra-se incompatível com os ideais liberais? A busca pelo autogoverno encerra preocupações antiliberais? No tocante a tais perguntas, Norberto Bobbio e Isaiah Berlin, dois dos mais importantes filósofos políticos dos últimos tempos, mostram uma divergência pontuada por argumentos que tornam claros os importantes valores envolvidos. Enquanto Bobbio descreve liberalismo e democracia como mutuamente dependentes - ressaltando, em especial, o fato de ambos terem nascido no seio de uma concepção individualista de ser humano -, Berlin descreve-os como ideais, em certo sentido, conflitantes, ressaltando a incompatibilidade entre a liberdade democrática e o pluralismo por ele defendido. Nesse capítulo, veremos que essa divergência nos oferece algumas pistas acerca do papel exercido pelo princípio majoritário.

No terceiro capítulo, apresentaremos alguns argumentos em favor da tese conciliatória de Norberto Bobbio. Ian Shapiro, um contemporâneo pensador da ciência política, defende que as mais importantes e recentes teorias de justificação do Estado têm enfrentado problemas para compatibilizar dois valores centrais na tradição filosófica do Iluminismo: a proteção das liberdades individuais e o apego ao racionalismo científico. Seguindo de perto a exposição de Shapiro - mas sem a pretensão de desenvolver uma reflexão percuciente sobre o Iluminismo e as tradições que se lhe seguiram -, observaremos como a democracia pode ser considerada o ideal de arranjo político que melhores recursos oferece para a conciliação desses valores, especialmente quando adaptados pelo Iluminismo maduro, e veremos como essa reflexão implica uma grande aproximação entre democracia e a defesa do pluralismo defendido por Isaiah Berlin. Ainda no capítulo terceiro, examinaremos o utilitarismo de John Stuart Mill e as dificuldades que envolvem o princípio do dano. Analisaremos de que modo Mill concilia o racionalismo de seu pensamento utilitarista com a defesa intransigente da liberdade humana e qual a função do governo popular nesse esforço conciliatório.

No quarto capítulo, será a vez de examinarmos a relevância do princípio majoritário: levaremos em conta os argumentos a seu favor e as limitações teoricamente exigidas para seu justo funcionamento. Inclui-se nesse capítulo uma exposição sobre a admirável defesa que Jeremy Waldron faz da regra da maioria. Veremos de que modo o princípio majoritário pode ser considerado uma prática decisória respeitável. As habituais 
críticas de arbitrariedade e de desrespeito aos direitos individuais podem ser respondidas com base nessa consideração, o que nos permitirá dizer, ainda nesse capítulo, de que modo o princípio de dano de John Stuart Mill delineia limites para o princípio majoritário. No quinto e derradeiro capítulo, teceremos considerações finais sobre o tema.

\section{5 - Regra da maioria}

\subsection{1 - Democracia}

Filósofos, juristas e economistas têm concebido a democracia como um conjunto de regras que estabelecem "como devem ser tomadas as decisões coletivas"26. Norberto Bobbio compartilha dessa ideia. Segundo ele, esse conjunto pode ser resumido em seis regras essenciais, entre as quais estão o sufrágio universal, a estrita igualdade entre os votos dos cidadãos e a regra da maioria numérica - ou, tal como a define Bobbio, a regra segundo a qual, seja para as eleições, seja para as decisões coletivas, "será considerado eleito o candidato ou será considerada válida a decisão que obtiver o maior número de votos" ${ }^{27}$. Nesses termos, a regra da maioria é condição necessária à existência de uma democracia, embora não seja condição suficiente: para Bobbio, a democracia caracteriza-se pelo sufrágio universal aferido segundo a vontade da maioria ${ }^{28}$. De modo que, nessa concepção procedimental de democracia, a regra da maioria exerce um papel de muita relevância.

\subsection{2 - Definições, falhas e limites}

Para Hans Kelsen, liberdade política é a conformidade entre a vontade individual e a vontade coletiva. Segundo ele, não obstante seja inevitável a discordância entre a vontade do indivíduo e as vontades a ele exteriores, a democracia exige que tal discordância se reduza ao mínimo. Por entender que a regra da maioria satisfaz essa exigência, Kelsen a descreve como um instrumento capaz de maximizar a liberdade

\footnotetext{
${ }^{26}$ BOBBIO, Norberto. Teoria geral da política: a filosofia e as lições dos clássicos. Op. cit., p. 426. Trata-se da chamada concepção procedimental da democracia.

${ }^{27}$ BOBBIO, Norberto. Teoria geral da política: a filosofia e as lições dos clássicos. Op. cit., p. 427.

${ }^{28}$ A respeito da definição de Bobbio, veja-se CAMPILONGO, Celso Fernandes. Direito e Democracia. 2. ed. Editora Max Limonad, 2000, p. 35.
} 
política dos indivíduos: um princípio que constitui a "máxima aproximação possível à ideia de liberdade política" e que "pressupõe, como condição essencial, o princípio da igualdade" 29 . A síntese entre liberdade e igualdade está na base do relativismo filosófico que Kelsen associa à sua concepção de democracia. Daí, a importância do princípio majoritário também como ferramenta desse relativismo ${ }^{30}$.

Já Edoardo Ruffini, a ela se refere como a “comuníssima regra pela qual, em uma coletividade, deve prevalecer aquilo que quer a maioria e não o que quer a minoria" ${ }^{31}$. Para Ruffini, o princípio majoritário não tem em si razão de ser, podendo adquiri-la ou não, a depender do modo como e do âmbito onde é aplicado: é simplesmente uma fórmula de direito, não um instituto jurídico ${ }^{32}$. Trata-se, contudo, de uma fórmula cuja aplicação "tem como pressuposto um dos princípios mais justos, porém menos naturais: o de que todos os homens são iguais entre si" ${ }^{\prime 33}$.

Elaine Spitz, em uma excelente monografia sobre o tema, descreve-a como uma prática social capaz de manter a sociedade unida. Trata-se, segundo ela, de uma prática pensada com o objetivo de possibilitar a uma coletividade soberana, formada por pessoas politicamente iguais, a tomada de decisões sobre o curso de suas ações, sem a necessidade de se recorrer ao uso da força ${ }^{34}$.

É de Celso Fernandes Campilongo uma importante monografia publicada no Brasil sobre a regra da maioria que, desenvolvida sob o prisma da sociologia do direito, oferece uma clara exposição das relações entre Estado de direito e as práticas decisórias majoritárias, num contexto de crise e transformação dos Estados nacionais. A obra iniciase com a afirmação de que a regra da maioria é um dos procedimentos que organizam as relações entre direito e democracia ${ }^{35}$. Porém, a certa altura de seu trabalho, Campilongo sugere uma definição mais completa, porque tributária das contribuições oferecidas por vários autores que buscaram descrever a regra da maioria:

\footnotetext{
${ }^{29}$ KELSEN, Hans. A democracia. Traduzido por Ivone Castilho Benedetti, Jefferson Luiz Camargo e Marcelo Brandão Cipolla. São Paulo: Martins Fontes, 2000, p. 179. CAMPILONGO, Celso Fernandes. Direito e Democracia, Op. cit., p. 34-35.

${ }^{30}$ KELSEN, Hans. A democracia. Op. cit., pp. 161-167 e p. 180.

${ }^{31}$ RUFFINI, Edoardo. Il principio maggioritario: profilo storico. Op. cit., p. 11 (tradução livre).

${ }^{32}$ RUFFINI, Edoardo. Il principio maggioritario: profilo storico. Op. cit., p. 94.

${ }^{33}$ RUFFINI, Edoardo. Il principio maggioritario: profilo storico. Op. cit., p. 11 (tradução livre).

${ }^{34}$ SPITZ, Elaine. Majority rule. Chatham: Chatham House Publishers, 1984, p. 211 (tradução livre).

${ }^{35}$ CAMPILONGO, Celso Fernandes. Direito e Democracia. Op. cit., p. 13.
} 
A regra da maioria é uma técnica rápida de tomada de decisões coletivas que maximiza a liberdade individual e assegura a ampla e igual participação política dos cidadãos, aproximando governantes e governados por meio de uma prática social de legitimação eventual, finita no espaço e no tempo, que sujeita as decisões à contínua revisão e mantém a sociedade unida ${ }^{36}$.

Em tais descrições da regra da maioria - que são, ao mesmo tempo, formas de justificá-la - aponta-se ora a utilidade (ou mesmo a imprescindibilidade) desse procedimento para a formação de decisões coletivas, ora sua aptidão para manter unidos os membros de uma comunidade ou simplesmente para incrementar a liberdade de cada um deles.-

Os autores que tratam do tema, em geral, entendem que, apesar de seu incontestável valor, o princípio majoritário apresenta problemas significativos. Já nos referimos, no início deste trabalho, a algumas críticas dirigidas à regra da maioria, tais como a acusação de irracionalidade ou de que essa regra não protege as minorias em face dos abusos majoritários. Quanto a essa última acusação, Edoardo Ruffini nos ensina que "a ideia de proteger as minorias limitando-se a aplicação do princípio majoritário nas deliberações do Parlamento" remonta às discussões havidas quando do estabelecimento das colônias inglesas na América, "um movimento que, tal como a Revolução Francesa, encontra suas raízes no jusnaturalismo" ${ }^{\text {37 }}$. Não é de hoje, portanto, o entendimento de que o princípio majoritário não deve ser aplicado em quaisquer circunstâncias: suas falhas exigem que, de algum modo, ele se submeta a limites.

Assim, por exemplo, um dos problemas geralmente atribuídos ao princípio majoritário é o fato de ele ser insensível à intensidade das preferências expressas nos votos - o que decorre naturalmente da exigência de que os votos tenham igual peso. Diante desse

\footnotetext{
${ }^{36}$ CAMPILONGO, Celso Fernandes. Direito e Democracia. Op. cit., p. 38. Cuida-se de uma proposta de definição que sintetiza as conceituações de Norberto Bobbio, Elaine Spitz, Hans Kelsen e que abrange também a definição de Elias Berg, segundo a qual "o princípio da maioria é uma técnica não discriminatória praticamente inevitável, que, dentro do seu campo de aplicação, tende a conferir influência para o máximo de indivíduos", em CAMPILONGO, Celso Fernandes. Direito e Democracia, Op. cit., p. 36.

${ }^{37}$ RUFFINI, Edoardo. Il principio maggioritario: profilo storico. Op. cit., p. 91 (tradução livre).
} 
problema, há quem afirme que a decisão majoritária não será legítima em situações nas quais seja possível supor diferenças drásticas entre as preferências dos votantes. ${ }^{38}$

Esse exemplo ressalta o modo como se relacionam duas ideias distintas: as limitações (falhas) atribuídas ao próprio funcionamento do princípio majoritário e os limites aos quais deve ele se submeter. No primeiro caso, cuida-se de problemas considerados inerentes à regra da maioria e constatados por meio da observação (ser). No segundo caso, falamos dos limites que devem ser impostos à regra da maioria (dever), quando sua aplicação indiscriminada puder gerar decisões consideradas injustas ou ilegítimas ou simplesmente inadequadas.

Reconhecemos aqui que essa distinção é bem menos simples do que aparenta. $\mathrm{Na}$ verdade, muitos autores citam uma lista de limites do princípio majoritário, mas nem sempre fica claro quando estão apontando falhas do princípio e quando estão falando de limites a serem impostos. E tal obscuridade é até bastante compreensível quando se tem em mente que a imposição de limites ao princípio majoritário é geralmente uma consequência dos defeitos que esse princípio parece ostentar: e a confusão entre causa e efeito não é privilégio da filosofia política. Mesmo Norberto Bobbio, ao tratar dos limites da regra da maioria, em que pese a habitual clareza com que expõe suas ideias, não logra arrostar essa confusão. Quanto a esse aspecto, a distinção que Bobbio faz entre limites e aporias da regra da maioria não traz esclarecimentos, embora se mostre útil para a compreensão dos argumentos em prol dessa regra. Segundo ele, as aporias são "dificuldades internas à aplicação da regra considerada unicamente como expediente técnico" - e, por isso, concernentes apenas à dimensão técnica do problema - enquanto os limites concernem a sua dimensão axiológica ${ }^{39}$.

Seja como for, os diversos limites cuja imposição tem-se considerado necessária são sempre respostas a uma mesma pergunta: Em que ocasiões a regra da maioria não deve prevalecer? Por isso, podemos dizer que, não obstante Bobbio fale em três categorias de limites (de validade, de aplicação e de eficácia), em todos os casos a

\footnotetext{
${ }^{38}$ Nesse sentido OFFE, Claus. "Legitimação política por decisão majoritária?". In: Problemas estruturais do Estado capitalista. Traduzido por Barbara Fraitag. Rio de Janeiro: Ed. Tempo Brasileiro, 1984, pp. 334-335.

${ }^{39}$ BOBBIO, Norberto. Teoria geral da política: a filosofia e as lições dos clássicos. Op. cit., p. 448. Ao tratar dos limites de aplicação da regra majoritária, Bobbio afirma que eles "derivam da existência de matérias às quais a regra geralmente não se aplica" (grifo nosso), em BOBBIO, Norberto. Teoria geral da política: a filosofia e as lições dos clássicos. Op. cit., p. 443.
} 
preocupação é a mesma: proibir o uso do princípio majoritário quando ele puder gerar decisões injustas ou inadequadas para o fim a que se propõem.

Entre esses limites está a proibição (e não exatamente a impossibilidade $)^{40}$ de se usar a própria regra da maioria para revogá-la. A razão de tal limite - que Bobbio chamou limite de validade - explica-se quando consideramos a regra da maioria como uma meta-regra, isto é, como uma regra sobre as regras de decisão, ou quando consideramos que é da natureza de um princípio proibir sua própria negação ${ }^{41}$. Entre os limites também está a proibição de se formar uma decisão irreversível, pois isso limitaria o direito das gerações futuras de se valer do princípio majoritário ${ }^{42}$.

Entretanto, dos limites em geral citados pelos autores que estudaram o tema, aquele que mais nos interessa é o que impede o uso da regra da maioria para a formação de decisões concernentes à "área das disposições privadas". Isto é: o limite que impede a aplicação da regra em relação a questões que dizem respeito apenas ao indivíduo ${ }^{43}$. E sua relevância está em que, embora os autores aqui estudados não façam referência ao princípio do dano de John Stuart Mill, é exatamente esse limite que o princípio do dano vem estabelecer. Esse limite à regra da maioria é apenas uma versão mais restrita daquele princípio. Mas estabelecer esse limite implica as mesmas dificuldades enfrentadas pelos teóricos para se distinguir entre as esferas pública e privada. Dificuldades que, desde Stuart Mill, estão associadas à necessidade de se responder quais ações produzem danos a terceiros e quais não.

\footnotetext{
${ }^{40}$ Nas palavras de Robert Dahl: "Empiricamente, é obviamente verdadeiro que o demos pode resolver empregar processos democráticos para destruí-lo". DAHL, Robert. Um prefácio à democracia econômica. Traduzido por Ruy Jungmann. Rio de Janeiro: Jorge Zahar Editor Ltda., 1990, p. 31.

${ }^{41}$ BOBBIO, Norberto. Teoria geral da política: a filosofia e as lições dos clássicos. Op. cit., p. 443. A certa altura de sua obra Um prefácio à democracia, Dahl nos oferece uma justificação bem menos persuasiva desse limite - e, aparentemente, até um pouco ingênua. Afirma esse autor: "Se o povo acredita que a democracia é desejável e justificada, logicamente ele não pode simultaneamente acreditar que ela é indesejável e, por conseguinte, justificar a destruição do processo democrático" (DAHL, Robert. Um prefácio à democracia econômica, p. 32). Na verdade, porém, não é ilógico que um povo insatisfeito com a democracia utilize do processo democrático para combatê-la: ele não estará abdicando do direito exercido naquele momento, mas do direito que exerceria no futuro. Ver também SPITZ, Elaine. Majority rule. Op. cit., p. xi e CAMPILONGO, Celso Fernandes. Direito e Democracia, Op. cit., pp. 49-50.

${ }^{42}$ BOBBIO, Norberto. Teoria geral da política. Op. cit., pp. 447-448. A esse limite, Bobbio chamou "limite de eficácia". Ver também: OFFE, Claus. "Legitimação política por decisão majoritária?". Op. cit., pp. 331334; e CAMPILONGO, Celso Fernandes. Direito e Democracia, Op. cit., p. 50.

${ }^{43}$ OFFE, Claus. "Legitimação política por decisão majoritária?". Op. cit., p. 325; BOBBIO, Norberto. Teoria geral da política: a filosofia e as lições dos clássicos. Op. cit., pp. 443-446., Celso Fernandes. Direito e Democracia, Op. cit., pp. 50-51.
} 


\subsection{3 - Regra da maioria e relativismo}

a) Direito natural e direito positivo

Quando indagamos se determinada atitude é certa ou errada, é fácil compreender o que se busca com tal questionamento: prescindindo-se de preceitos jurídicos ou religiosos, pretende-se buscar alguns princípios de notória prescritividade e universalidade, em conformidade com os quais devem estar as ações humanas. A dúvida que logo surge é quanto à existência dos ditos princípios. De uma maneira simplificada, podemos chamar de universalistas aqueles que afirmam tal existência e de relativistas aqueles que a negam. Essa oposição nos remete a uma das mais importantes dicotomias da teoria geral do direito: a dicotomia direito natural/direito positivo. Não tratamos aqui dessa dicotomia, senão por ela estar ligada a um aspecto importante do princípio majoritário, relacionado, de algum modo, à acusação de arbitrariedade que normalmente lhe é dirigida.

O direito natural é um paradigma de pensamento em cuja elaboração doutrinária encontra-se a noção de princípios universais e imutáveis aos quais somente se pode chegar por meio da razão, da intuição ou da revelação ${ }^{44}$. As diversas doutrinas de direito positivo, ao contrário, mantêm em comum a compreensão de que o direito provém do arbítrio humano e é posto pela autoridade ${ }^{45}$. Os filósofos jusnaturalistas entendem o direito natural como uma espécie de modelo em que o direito positivo deve se espelhar. Sabemos que, apesar da grande influência exercida pelo direito natural, o processo de codificação e sistematização das normas jurídicas iniciado no século XIX e a permanente constatação de ordenamentos jurídicos que variam no espaço e no tempo contribuíram para a dissolução desse paradigma ${ }^{46}$. $\mathrm{O}$ declínio da dicotomia direito natural/direito positivo culminou com o predomínio da dogmática jurídica - predomínio que faz prevalecer, no

\footnotetext{
${ }^{44}$ LAFER, Celso. A reconstrução dos direitos humanos - Um diálogo com o pensamento de Hannah Arendt. São Paulo, Companhia das Letras, 1988, pp. 36-37.

45 “A ideia de direito positivo é a ideia de uma disposição que chegou a ser direito de maneira arbitrária, que é considerada como fonte de direito em virtude de algum fato ou ação que não tem nenhuma conexão intrínseca com o conteúdo, a substância ou a qualidade da própria disposição". WALDRON, Jeremy. Derecho y desacuerdos. Traduzido ao espanhol por José Luis Martí e Águeda Quiroga. Madrid: Marcial Pons Ediciones Jurídicas y Sociales, 2005, p. 113 (tradução livre).

${ }^{46}$ LAFER, Celso. A reconstrução dos direitos humanos... Op. cit., pp. 38-39. Ver também: FERRAZ JÚNIOR, Tércio Sampaio. Introdução ao estudo do direito: técnica, decisão, dominação. 4. ed. São Paulo: Editora Atlas, 200, p. 170.
} 
momento atual, a ideia de que o direito não deve "qualificar eticamente como boas ou más as condutas, mas sim servir de instrumento de gestão da sociedade"47.

A prevalência do paradigma juspositivista gera, no entanto, um desconforto. A arbitrariedade a ele inerente subtrai ao direito a moralidade sem que, por isso, perca ele validade $^{48}$. Por isso, a arbitrariedade não é bem vista no mundo jurídico. Como alerta um grande jurista de nosso tempo, malgrado não perca validade, o direito, privado de moralidade, perde sua dignidade intrínseca. A questão, segundo esse autor, é saber como as sociedades conseguem, ainda assim, sobreviver com esse direito ${ }^{49}$.

Um dos maiores positivistas do século XX, o austríaco Hans Kelsen, expôs a relação existente entre o positivismo jurídico e o que ele chamou de relativismo filosófico. Nas próximas páginas passaremos por tal exposição e pela defesa dessa postura relativista. Veremos, então, se essa defesa pode nos ajudar a compreender um pouco mais sobre a regra da maioria.

\section{b) Relativismo e universalismo}

À distinção deveras simplificada que ora fazemos entre universalismo e relativismo, podemos associar a distinção que Hans Kelsen faz entre absolutismo e relativismo filosófico. Na filosofia, diz Kelsen, especialmente no âmbito da epistemologia e da teoria dos valores, a postura relativista, ao contrário do absolutismo, nega a possibilidade de valores absolutos ou de uma verdade absoluta ${ }^{50}$. Para ele, o antagonismo entre absolutismo e relativismo filosófico "parece ser em muitos aspectos análogo à oposição fundamental entre a autocracia e a democracia, que representam respectivamente o absolutismo e o relativismo no domínio da política" ${ }^{\text {. }}$.

Tal como o absolutismo político, o absolutismo filosófico tende a ser pouco afeito à liberdade individual, pois concebe o sujeito cognoscente como um ser subordinado

\footnotetext{
${ }^{47}$ LAFER, Celso. A reconstrução dos direitos humanos..., op. cit., pp. 41-46.

${ }^{48}$ Dois dos maiores positivistas do século XX defendem que a identificação, pela ciência jurídica, do que é direito válido independe de qualquer indagação sobre sua moralidade. KELSEN, Hans. Teoria Pura do Direito. Traduzido por João Baptista Machado. 7. ed. São Paulo: Martins Fontes, 2006, pp. 67-78 e HART, Herbert L. A.. O conceito de direito. Traduzido por Antonio de Oliveira Sette-Câmara; pós-escrito e organizado por Penelope A. Bulloch e Joseph Raz. São Paulo: Editora WMF Martins Fontes, 2009, pp. 258259 e pp. 271-273.

${ }^{49}$ FERRAZ JUNIOR, Tércio Sampaio. Introdução ao estudo do direito... Op. cit., pp. 358-359.

50 KELSEN, Hans. A democracia. Traduzido por Ivone Castilho Benedetti, Jefferson Luiz Camargo e Marcelo Brandão Cipolla. São Paulo: Martins Fontes, 2000, pp. 161-163.

${ }^{51}$ KELSEN, Hans. A democracia. Op. cit., p. 345.
} 
às inexoráveis leis da realidade objetiva. Além disso, o uso deste por aquele como instrumento ideológico tem sido comum ao longo da história. A epistemologia relativista, ao contrário, por descrer da existência de uma realidade objetiva, concebe o sujeito conhecedor como criador de seu próprio mundo. Assim, a liberdade individual é pressuposto tanto do relativismo filosófico, quanto do relativismo político inerente aos governos democráticos ${ }^{52}$. Para Kelsen, o paralelismo fica ainda mais evidente quando consideramos que os grandes representantes do relativismo filosófico (Protágoras, Locke, Hume) foram entusiastas da democracia, ao passo que grandes pensadores do absolutismo filosófico (“os grandes metafísicos”, como Platão, Aristóteles e Hegel) mostraram-se contrários à democracia e receptivos ao absolutismo político ${ }^{53}$.

Não fica perfeitamente claro o papel exercido pelo princípio majoritário na concepção kelseniana de democracia, mas é possível dizer que Kelsen atribuía-lhe um valor superior diante do relativismo político. Sobre isso, afirma Hans Kelsen:

Quando se reconhece que só valores relativos são acessíveis ao conhecimento e à vontade humanas, a imposição de uma ordem social sobre indivíduos relutantes só se justifica se tal ordem estiver em harmonia com a vontade do maior número de indivíduos iguais ${ }^{54}$.

Às vezes, a regra da maioria parece ser a própria afirmação do relativismo filosófico e seu uso parece ser justificado pela inexistência de uma verdade absoluta - ou, simplesmente, pela impossibilidade de a alcançarmos. De fato, se pudéssemos alcançar a verdade sobre o que é moralmente correto, os rumos de uma comunidade não seriam traçados por meio de um artifício que atribui à maioria a prerrogativa de escolher.

Mas essa relação com o relativismo demonstra necessariamente uma natureza arbitrária? Arbitrariedade é uma falha que se atribui tanto ao princípio

\footnotetext{
${ }^{52}$ KELSEN, Hans. A democracia. Op. cit., pp. 348-349.

${ }^{53}$ KELSEN, Hans. A democracia. Op. cit., pp. 350-354. Segundo Hans Kelsen, malgrado seja Kant um caso à parte, sua história também corrobora tal tese: no âmbito da filosofia da natureza, Kant demonstrou a futilidade da metafísica, mas reintroduziu o conceito de absoluto em sua ética; do mesmo modo, no âmbito da política, mostrou-se dúbio e parecia não exprimir sua verdadeira opinião. KELSEN, Hans. A democracia. Op. cit., p. 354.

${ }^{54}$ KELSEN, Hans. A democracia. Op. cit., pp. 355-356. CAMPILONGO, Celso Fernandes. Direito e Democracia, Op. cit., p. 34-35
} 
majoritário, quanto ao positivismo jurídico. Daí a asserção de Jeremy Waldron, segundo a qual o desconforto em face do princípio majoritário é apenas um aspecto do desconforto mais geral que há em relação ao positivismo jurídico ${ }^{55}$.

A acusação de arbitrariedade, entretanto, requer um exame mais percuciente. É preciso indagar se, por exemplo, permitir que a maioria decida pela coletividade é tão arbitrário quanto permitir que uma só pessoa o faça; ou se decidir pela regra da maioria é, realmente, o mesmo que o fazer jogando dados. No Capítulo 2, observaremos que o relativismo ao qual se associa o princípio majoritário não se traduz em um completo niilismo; que o enfoque positivista pode estar, mais do que se costuma imaginar, ligado a importantes valores. E no capítulo 4, veremos como a acusação de arbitrariedade pode ser tranquilamente rebatida.

Para se encerrar este capítulo introdutório, cumpre dizer algo sobre o paternalismo.

\section{6 - Paternalismo}

No Dicionário de Política, de Bobbio, Matteucci e Pasquino, ao verbete "Paternalismo" liga-se a seguinte informação: na linguagem vulgar, o termo é normalmente utilizado para indicar "uma política orientada para o bem-estar dos cidadãos e do povo, mas que exclui a sua direta participação" ${ }^{\text {"56 }}$. Malgrado tratar-se de uma definição bastante conveniente para iniciarmos nosso estudo - pois, ao mesmo tempo em que nos revela o uso comum do termo, ela evidencia sua aplicação nas relações entre Estado e cidadãos - a nos guiarmos por ela, deixaríamos de explicitar as dificuldades e controvérsias que o termo envolve. E elas são inúmeras. O próprio Dicionário menciona diversos sentidos atribuídos à palavra e expõe um breve histórico de seu uso. Não há como

\footnotetext{
${ }^{55}$ WALDRON, Jeremy. Derecho y desacuerdos. Op. cit., pp. 113-115.

56 MATTEUCCI, Nicola. "Paternalismo". In: BOBBIO, Norberto; MATTEUCCI, Nicola; PASQUINO, Gianfranco. Dicionário de política - Vol. 2. Traduzido por Carmen C. Varriale et. al. 12. ed. Brasília: UNB, 2004, p. 908.
} 
negar, a delimitação conceitual do termo "paternalismo" tem-se mostrado extraordinariamente difícil ao longo da história ${ }^{57}$.

Quando se diz que determinados grupos, ou governos, agem de maneira paternalista, faz-se uma óbvia alusão ao tipo de relação que comumente existe entre pais e seus filhos menores. Ou, em outras palavras, faz-se uma analogia entre sua maneira de agir e o modo como os pais lidam com suas crianças. A analogia é, sobretudo, uma forma de argumentar. Aquele que usa a analogia destaca uma semelhança relevante entre termos expostos à comparação.

A relação entre pais e filhos, contudo, como qualquer relação humana, é complexa e, bem por isso, tem uma multiplicidade de aspectos que podem, dependendo do objetivo, ser ressaltados e expostos à comparação. Assim, o comportamento de alguém que busca proteger ou promover o bem estar de outra pessoa é, em certo aspecto, paternalista, pois nesse caso, o que se põe em relevo na analogia é o dever paterno de buscar o bemestar dos filhos. A conduta de alguém que auxilia outrem a conquistar alguma forma de independência é também paternalista, pois ninguém duvidaria que a educação dada pelos pais aos filhos tem a função precípua de torná-los independentes no futuro. Em todos esses casos, porém, o termo paternalista carrega em si aspectos louváveis da relação pai-filho.

No entanto, ao longo da história, o termo "paternalismo" tem sido usado para ressaltar características bem menos dóceis dessa relação: o enorme poder dos pais sobre os filhos, a indiferença daqueles em relação à vontade destes, a certeza dos pais de que sabem, melhor do que os filhos, o que lhes é conveniente. Conforme se destacam uns ou outros aspectos, a analogia adquire menor ou maior carga pejorativa e sua conotação vai ganhando diferentes contornos.

Por isso, as grandes discussões que, nos últimos anos, têm sido travadas no tocante ao que seria um paternalismo aceitável (justificado) passam pela discórdia quanto ao que pode ser chamado paternalismo.

\footnotetext{
${ }^{57}$ GARCÍA, Macario Alemany. El concepto y la justificación del paternalismo. Tese apresentada à Área de Filosofia do Direito da Faculdade de Direito da Universidade de Alicante, para a obtenção do título de Doutor em Direito (sob a orientação de Manuel Atienza e Juan Ruiz Manero), 2005, p. 514. Disponível em http://www.archivochile.com/tesis/13_otros/13otros0013.pdf.
} 
Gerald Dworkin, por exemplo - cujo artigo "Paternalism", publicado pela primeira vez em 1971, deu início a um instigante debate sobre o tema -, define o paternalismo como "a interferência na liberdade de ação de uma pessoa justificada por razões que se referem exclusivamente ao bem estar, bem, felicidade, necessidades, interesses ou valores da pessoa coagida" ${ }^{, 5}$.

Já para Ernesto Garzón Valdés - autor que contribuiu para introduzir o tema do paternalismo na jusfilosofia de língua espanhola, com um influente ensaio chamado “¿És éticamente justificable el paternalismo jurídico?”-, o termo tem sentido mais restrito. Segundo ele, paternalismo é a "intervenção coativa no comportamento de uma pessoa a fim de evitar que ela cause danos a si mesma",59.

Todavia, a formulação mais cuidadosa sobre os possíveis significados da palavra "paternalismo" parece ter sido engendrada por Joel Feinberg, professor de Filosofia na Universidade do Arizona. Em sua obra Filosofia social, conceituou o paternalismo como o princípio limitativo da liberdade que "justifica a coerção por parte do Estado para a proteção dos indivíduos contra danos auto-infligidos ou, em sua versão mais extrema, para guiá-los, gostem ou não, em seu próprio bem"60. Já em trabalho posterior, Feinberg demonstrou ainda mais zelo no estudo do tema. Considerou vários tipos de normas paternalistas e expôs muitas distinções relevantes para sua compreensão: a distinção entre normas paternalistas que proíbem determinadas condutas e normas que tornam condutas obrigatórias; entre normas cujo propósito é totalmente paternalista e normas híbridas, produzidas por razões não somente paternalistas; entre normas paternalistas que visam à prevenção de danos auto-infligidos e aquelas que buscam, de um modo geral, beneficiar o indivíduo ou aumentar seu bem-estar ${ }^{61}$.

Por outro lado, esse autor considerou necessário distinguir, com base no grau de voluntariedade presente no momento da coação estatal, entre "hard paternalism"

\footnotetext{
${ }^{58}$ DWORKIN, Gerald. "Paternalism". Op. cit., p. 331 (tradução livre). Sobre a repercussão da obra de Gerald Dworkin, veja-se: GARCÍA, Macario Alemany. El concepto y la justificación del paternalismo. Op. cit., p. 88.

${ }^{59}$ VALDÉS, Ernesto Garzón. “EÉs éticamente justificable el paternalismo jurídico?”. In: Doxa, nº 05, 1988, p. 155. Disponível em http://bib.cervantesvirtual.com/servlet/SirveObras/12471730982570739687891/cuaderno5/Doxa5_08.pdf. ${ }^{60}$ FEINBERG, Joel. Filosofia social. Traduzido por Alzira Soares da Rocha e Helena Maria Camacho. Rio de Janeiro: Zahar Editores, 1974, p. 73.

${ }^{61}$ FEINBERG, Joel. The moral limits of the criminal law. $3^{\circ}$ vol. - Harm to self. New York: Oxford University Press, 1986, pp. 08-09.
} 
("paternalismo duro") e "soft paternalism" ("paternalismo brando"). Segundo Feinberg, o paternalismo brando, ou fraco, sustenta o direito de o Estado impedir danos auto-infligidos, mas apenas quando a conduta danosa mostrar-se "substancialmente não-voluntária", ou quando for necessária uma intervenção temporária para se constatar a voluntariedade de tal conduta $^{62}$. Trata-se, segundo esse autor, de "uma forma tão fraca e inócua de paternalismo que seria aceita até mesmo por John Stuart Mill"63. De modo que para Feinberg, a rigor - e dada a carga pejorativa que pesa sobre o termo -, o paternalismo dito brando nem deveria ser chamado paternalismo ${ }^{64}$.

É óbvio que, nesse contexto de controvérsias terminológicas, pode haver discordância quanto a uma determinada conduta ser considerada paternalista ou não. Assim, por exemplo, Gerald Dworkin, em seu artigo "Paternalism", considera paternalistas as leis que pró́bem a prática consensual de relações homossexuais entre duas pessoas adultas. Para Joel Feinberg, ao revés, não se trata de paternalismo, pois, segundo ele, quando o Estado combate esse tipo de conduta não o faz em consideração ao bem estar de quem a pratica, mas porque a reconhece como ameaçadora ou repugnante ${ }^{65}$.

Mas, apesar das inúmeras controvérsias, esses autores têm em comum, primeiramente, o fato de abordarem o tema a partir do reconhecimento prévio de que existem em nossas sociedades "medidas francamente paternalistas que parecem ter um elevado grau de plausibilidade" 66 . Isto é, esses pensadores parecem admitir que a rejeição total do paternalismo - no sentido em que o termo é vulgarmente utilizado - equivale a desprezar o senso comum e a resistir aos costumes e leis que fazem parte de nossa história e de nosso dia-a-dia ${ }^{67}$. Em segundo lugar, ao buscar alguma forma de justificação do paternalismo estatal, todos eles partem do princípio enunciado por John Stuart Mill. E, curiosamente, embora teçam severas críticas ao ensaio de Mill, todos buscam demonstrar que as respectivas teorias seriam aceitas por Stuart Mill, caso ele as pudesse conhecer.

$\mathrm{Na}$ tentativa de pontuar sinteticamente a visão de cada um desses pensadores, podemos dizer que, para eles, intervenções paternalistas são aceitáveis: i)

\footnotetext{
${ }^{62}$ FEINBERG, Joel. The moral limits of the criminal law... Op. cit., p. 14 (tradução livre).

${ }^{63}$ FEINBERG, Joel. Filosofia social. Op. cit., p. 79.

${ }^{64}$ FEINBERG, Joel. The moral limits of the criminal law... Op. cit., p. 16.

${ }^{65}$ DWORKIN, Gerald. "Paternalism". Op. cit., p. 332. FEINBERG, Joel. The moral limits of the criminal law... Op. cit., p.17.

${ }^{66}$ VALDÉS, Ernesto Garzón. “¿És éticamente justificable el paternalismo jurídico?”. Op. cit., p. 156.

${ }^{67}$ FEINBERG, Joel. Filosofia social. Op. cit., p. 73
} 
quando protegem ou promovem o poder de escolha da pessoa cuja liberdade se restringe (Dworkin); ii) quando auxiliam essa pessoa a superar sua incapacidade de fazer frente aos desafios e problemas com que se depara (Garzón Valdés); iii) ou quando o comportamento restringido é substancialmente não-voluntário (Feinberg).

Embora não seja o objetivo desta dissertação o aprofundamento sobre as teorias de justificação do paternalismo, as principais preocupações desses autores estão presentes neste estudo. Como elas se relacionam com a legitimação do Estado democrático é algo que veremos nos capítulos que se seguem a esta introdução. 


\section{CAPÍTULO II - LIBERALISMO E DEMOCRACIA}

Quaisquer que sejam as consequências danosas da liberdade em determinado caso, há sempre um efeito direto sobre a pessoa que a possui, efeito esse que deve ser considerado um bem positivo. (...) A ser isso verdade, há sempre uma suposição a favor da liberdade, muito embora ela possa, em alguns casos, ser sobrepujada por razões mais poderosas.

(Joel Feinberg) ${ }^{68}$

\section{1 - Dois conceitos de liberdade}

John Stuart Mill era, ao mesmo tempo, um liberal e um democrata. Esforçou-se para elaborar seu princípio do dano, porque desejava conciliar o ideal de um governo popular com o ideal de governo liberal que defendia.

Mas, onde estava a dificuldade para compatibilizar esses dois ideais. Seriam liberalismo e democracia conceitos antagônicos? Essa dúvida foi levemente insinuada por Benjamin Constant quando, em 1819, ele proferiu um famoso discurso no Ateneu Real de Paris. Nesse discurso, ele expôs, pela primeira vez, aquela que seria uma de suas enunciações mais célebres - a distinção entre a liberdade dos antigos e a liberdade dos modernos.

${ }^{68}$ FEINBERG, Joel. Filosofia social. Traduzido por Alzira Soares da Rocha e Helena Maria Camacho. Rio de Janeiro: Zahar Editores, 1974, p. 40. 
Segundo Constant, o conceito de liberdade comungado na antiguidade clássica grega estava intimamente relacionado com o ideal democrático de distribuição do poder entre todos os cidadãos da pátria, ao passo que o conceito utilizado pelos modernos guardava relação com a segurança necessária às fruições privadas da vida ${ }^{69}$. Para ele, esses eram conceitos distintos, às vezes contrastantes entre si e não restava dúvida de que, em caso de conflito, deveríamos optar pela liberdade dos modernos ${ }^{70}$. Apesar disso, no final de seu discurso, Benjamin Constant parece reconhecer a possibilidade de convívio entre democracia e liberalismo, quando afirma que é preciso aprender a conciliar as duas liberdades $^{71}$.

Desde a publicação desse célebre discurso, a exposição de Constant acerca das duas liberdades foi contestada por muitos motivos diferentes ${ }^{72}$. A maneira como modernos e antigos concebiam a ideia de liberdade é tema que comporta uma profunda e complexa discussão e não cabe, nos estritos limites deste estudo, adentrar debate tão amplo e controvertido. Não obstante, a despeito do erro ou acerto no qual tenha incorrido a distinção traçada por Benjamin Constant, o fato é que ela se revelou de extrema importância para qualquer debate que se mantenha acerca convívio entre democracia e liberalismo.

Nesse ponto, vale a pena mencionar dois autores que, seguindo a lição de Constant, também desenvolveram relevantes reflexões sobre as relações entre liberalismo e democracia, utilizando-se da consagrada distinção.

${ }^{69}$ CONSTANT, Benjamin. "Da liberdade dos antigos comparada à dos modernos". Traduzido por Loura Silveira. In: Revista Filosofia Política, $\mathrm{n}^{\circ}$ 2, 1985, pp. 01-07. Disponível em http://www.fflch.usp.br/dh/heros/antigosmodernos/seculoxix/constant/liberdadeantigos.html.

70 "Se vivemos nos tempos modernos, quero a liberdade que convém aos tempos modernos", em CONSTANT, Benjamin. "Da liberdade dos antigos...". Op. cit., p. 05. Ver também BOBBIO, Norberto. Liberalismo e democracia. Tradução de Marco Aurélio Nogueira. 6. ed. São Paulo: Brasiliense, 2006, p. 08 e LAFER, Celso. "O moderno e o antigo conceito de liberdade". In: Ensaios sobre a liberdade. São Paulo: Ed. Perspectiva, 1980, p. 11.

${ }^{71}$ CONSTANT, Benjamin. "Da liberdade dos antigos...". Op. cit., p. 07: "Longe, pois, Senhores, de renunciar a alguma das duas espécies de liberdade de que vos falei, é preciso aprender a combiná-las".

${ }_{72}$ O professor Miguel Reale oferece-nos uma abrangente e erudita exposição dessas contestações. Segundo Reale, à indagação sobre se "os gregos e romanos realizaram, em sua experiência política, tão rica em doutrinas, o valor jurídico da liberdade", cada pensador oferecerá uma resposta diversa, influenciado que esteja pelos anseios de sua época e pela ideologia que comunga com os outros de seu tempo. Assim, por exemplo, "escrevendo no clima do Renascimento, um Machiavelli responderá afirmativamente", ao passo que "será diversa e contrastante a resposta de um Benjamin Constant ou de um Fustel de Coulanges, sob o signo do liberalismo ou a pressão de forças românticas". REALE, Miguel. Horizontes do direito e da história. 3. ed. São Paulo: Saraiva, 2000, p. 04. 
Norberto Bobbio e Isaiah Berlin, dois dos mais respeitados cientistas políticos dos últimos tempos, tiveram em comum, além do entusiasmo pelo valor da liberdade humana, uma honesta curiosidade pelos grandes problemas políticos que marcaram a geração a que pertenciam, dentre os quais estava o convívio entre liberalismo e democracia. No presente trabalho, além dos imprescindíveis apontamentos tecidos sobre o tema, interessa-nos especialmente a divergência que ambos mantinham em alguns pontos importantes.

Em seus escritos, Bobbio descreveu a democracia como um aperfeiçoamento do liberalismo. Para ele, não apenas liberalismo e democracia são compatíveis, mas, em certo sentido, a democracia pode ser vista "como o natural desenvolvimento do Estado liberal"73. Em sua obra Liberalismo e democracia, Bobbio afirma haver boas razões para se acreditar que os princípios básicos do Estado liberal (direitos humanos fundamentais) são tão necessários para o bom funcionamento do método democrático, quanto o método democrático é necessário para a salvaguarda desses princípios liberais: há, portanto, uma dependência recíproca entre liberalismo e democracia $^{74}$. Em outras ocasiões, para demonstrar tal interdependência, Norberto Bobbio utilizou-se, com precisão, da bem marcada distinção entre liberdade dos antigos e liberdade dos modernos. Segundo ele, esses dois significados atribuídos ao termo "liberdade" são igualmente legítimos e indicam estados igualmente desejáveis para o homem ${ }^{75}$. E a dependência recíproca entre essas duas dimensões da liberdade é registrada por Bobbio quando ele afirma a gradual integração dessas duas tendências ${ }^{76}$.

Bem ao contrário, Isaiah Berlin - em cujos escritos é possível notar o leve influxo de Constant e de sua ferrenha defesa da liberdade moderna - não vê afinidade necessária entre democracia e liberalismo. A democracia não está logicamente comprometida com o liberalismo e historicamente falhou em defender o mínimo de liberdade que os teóricos liberais sempre pregaram ${ }^{77}$. Para ele, as duas já mencionadas

\footnotetext{
${ }^{73}$ BOBBIO, Norberto. Liberalismo e democracia. Tradução de Marco Aurélio Nogueira. 6. ed. São Paulo: Brasiliense, 2006, p. 42.

${ }_{75}^{74}$ BOBBIO, Norberto. Liberalismo e democracia. Op. cit., p. 43.

75 BOBBIO, Norberto. Teoria geral da política: a filosofia e as lições dos clássicos. Organizado por Michelangelo Bovero; traduzido por Daniela Beccaccia Versiani. 2. ed. Rio de Janeiro: Ed. Campus, 2000 , p. 280.

${ }_{77}^{76}$ BOBBIO, Norberto. Teoria geral da política, Op. Cit., p. 103.

77 BERLIN, Isaiah. Estudos sobre a humanidade: uma antologia de ensaios. Traduzido por Rosana Eichenberg; edição de Henry Hardy e Roger Hausheer. São Paulo: Companhia das Letras, 2002, p. 266.
} 
acepções da palavra liberdade não são, simplesmente, duas interpretações de um mesmo termo; ao contrário, elas traduzem preocupações "profundamente divergentes e irreconciliáveis"

Mas, de que modo essa diferença de opiniões pode nos auxiliar na reflexão sobre as relações entre a regra da maioria e a liberdade individual?

Em primeiro lugar, ela nos ajuda a compreender as dificuldades e as motivações que envolveram o empenho de John Stuart Mill para concertar seu liberalismo professo com o ideal do governo popular.

Depois, a distinção entre liberdade dos antigos e liberdade dos modernos, tal como descrita por Benjamin Constant, é uma distinção que opõe o ideal da participação democrática - e a regra da maioria que o instrumentaliza - ao ideal de uma vida sem interferências alheias. Assim, é tentador acreditar que uma teoria capaz de conciliar essas duas dimensões da liberdade seja igualmente capaz de amainar algumas das principais inquietações descritas nesta dissertação.

Por tais motivos, neste capítulo, dissertaremos sobre as lições que Norberto Bobbio e Isaiah Berlin proferiram a respeito dessas duas clássicas maneiras de se pensar a liberdade. No entanto, entendemos não ser possível apreciar a relevância atual dessas reflexões, sem antes apresentar alguns poucos, mas importantes, aspectos da evolução por que passou o conceito de liberdade, no curso de nossa tradição filosófica.

\subsection{1 - Evolução do conceito de liberdade na filosofia ocidental}

\subsubsection{1 - Liberdade na antiguidade clássica grega}

$\mathrm{Na}$ antiga Grécia, liberdade era expressão que se opunha à escravidão. A expressão eleutería (liberdade) tinha origem em eléuteros ("aquele que no grupo social pátrio não se submete a ninguém") ${ }^{79}$. A um só tempo, como explica Tercio Sampaio Ferraz Junior, esse termo surgido no período homérico designava tanto a relação de pertinência ao

\footnotetext{
${ }^{78}$ BERLIN, Isaiah. Estudos sobre a humanidade... Op. cit., 267.

${ }^{79}$ FERRAZ JR., Tercio Sampaio. Estudos de filosofia do direito: reflexões sobre o poder, a liberdade, a justiça e o direito. 2. ed. São Paulo: Editora Atlas, 2003, p. 77.
} 
grupo quanto a noção de não-submissão. Posteriormente, já no período clássico, a expressão passou a ser usada para se referir ao "status daquele que vive na polis, que é político nesse sentido estrito, no sentido de que vive na igualdade perante a lei" ${ }^{80}$.

Em outras palavras, para os antigos, liberdade era a participação ativa no poder coletivo, era autonomia em seu sentido originário: “o direito de se reger pela própria lei” ${ }^{\prime 81}$. Nesse sentido, portanto, liberdade não é ausência de normas ou de impedimentos, mas, ao contrário, é “a faculdade de obedecer apenas à lei exterior à qual se pode dar assentimento" $" 82$. Assim, uma vez que tinha o poder de dar a si próprio as leis às quais havia de se submeter, o indivíduo livre - em oposição àqueles que os gregos chamavam de escravos - era o cidadão, o homem que participava da criação das leis e das discussões em praça pública.

Não havia, entretanto, ligação dessa expressão com a noção, já captada pelos antigos gregos, de "ato voluntário", pois, conquanto já conhecessem a oposição entre ato voluntário e involuntário, o uso do termo eleutería não designava, em sua origem, um atributo da vontade ${ }^{83}$. A literatura épica expressava rudimentarmente essa noção de ato voluntário quando, por exemplo, mostrava o homem lutando contra seu próprio e inexorável destino. Numa oposição entre natureza e destino, embora fosse impossível para o indivíduo alterar o próprio destino, ele agia para tentar modificá-lo, quase como se sua natureza o exigisse. E, apesar da proximidade que alguns pensadores enxergaram entre autonomia e voluntariedade, a antiguidade clássica grega não chegou a usar o termo liberdade para conceituar aquilo que hoje chamaríamos de escolha deliberada ${ }^{84}$. Para Aristóteles, por exemplo, embora fosse essencialmente voluntária, a escolha individual somente seria uma escolha verdadeira se a decisão do querer fosse precedida por uma deliberação racional dos meios, para se chegar a um fim determinado pela natureza do indivíduo $^{85}$. Para o antigo grego, nas palavras de Tercio, "a liberdade não é um poder de escolha, mas uma necessidade interna de querer o próprio ser como sua mais alta

\footnotetext{
${ }^{80}$ FERRAZ JR., Tercio Sampaio. Estudos de filosofia do direito. Op. cit., p. 77.

${ }^{81}$ LAFER, Celso. "O moderno e o antigo conceito de liberdade". In: Ensaios sobre a liberdade. São Paulo: Ed. Perspectiva, 1980, p. 14.

${ }^{82}$ LAFER, Celso. "O moderno e o antigo conceito de liberdade". Op. cit., p. 14.

${ }^{83}$ FERRAZ JR., Tercio Sampaio. Estudos de filosofia do direito. Op. cit., p. 77-83.

${ }^{84}$ FERRAZ JR., Tercio Sampaio. Estudos de filosofia do direito. Op. cit., p. 82.

${ }^{85}$ GILSON, Étienne. O espírito da filosofia medieval.Traduzido por Eduardo Brandão. São Paulo: Martins Fontes, 2006, p. 376; LAFER, Celso. Hannah Arendt: pensamento, persuasão e poder. 2. ed. São Paulo: Paz e Terra, 1988, pp. 88-92; FERRAZ JR., Tercio Sampaio. Estudos de filosofia do direito. Op. cit., p 82.
} 
possibilidade, donde querer algo impossível é ser não-livre: não se pode querer o que não se pode, querer pressupõe poder, liberdade e necessidade convergem" ${ }^{\text {" }}$.

\subsubsection{2 - O livre-arbítrio}

Não por acaso, foi apenas com o advento do Cristianismo que a oposição entre necessidade e liberdade tornou-se objeto de uma reflexão filosófica mais profunda. A partir da doutrina cristã divulgada por Paulo de Tarso, introduziu-se a noção, desconhecida na filosofia grega, de que a vontade e o ato voluntário não estão necessariamente ligados. Paulo dizia ser possível querer algo que não se pode praticar ${ }^{87}$. Em sua lição estava presente a certeza de que o homem é livre para escolher entre querer e não querer e, bem por isso, responsável por sua escolha ${ }^{88}$. É o que Ettiene Gilson ensina:

Estamos aqui na origem de uma das noções medievais mais importantes, a da liberdade de exercício. Uma vontade é livre em vários sentidos diferentes, mas ela o é antes de mais nada pelo fato de que pode querer ou não querer exercer seu ato ou não exercê-lo, e essa primeira liberdade lhe é essencial. É o que os filósofos cristãos exprimem positivamente, identificando o livre arbítrio com a vontade, ou melhor, com o ato de escolher que a vontade exerce; porque, quando ela escolhe, ela quer; se ela quer, é ela que quer, mas também poderia não querer ${ }^{89}$.

Assim, a liberdade passa a ser vista como a mera vontade, que existe anterior e independentemente da realização do ato voluntário ${ }^{90}$. No fundo, mais que isso, a liberdade passa a ser vista como essa possibilidade de exercer, ou não, o ato voluntário e é assumida pelos filósofos medievais como o livre-arbítrio. Nasce daí, a compreensão de que

\footnotetext{
${ }^{86}$ FERRAZ JR., Tercio Sampaio. Estudos de filosofia do direito. Op. cit., p. 80.

87 "Eu sei que o bem não mora em mim, isto é, na minha carne. Pois o querer o bem está ao meu alcance, não porém praticá-lo" (Rm 7, 18).

${ }^{88}$ Segundo Hannah Arendt, isso fazia parte da compreensão pauliana acerca da diferença entre Antigo e Novo Testamento: “A Velha Lei dizia: não farás. A Nova Lei diz: não quererás. O que levou à descoberta da Vontade foi a experiência de um imperativo que exigia a submissão voluntária", em ARENDT, Hannah. $A$ vida do espírito: o pensar, o querer, o julgar. Traduzido por Antonio Abranches e Helena Franco Martins. 2. ed. Rio de Janeiro: Civilização Brasileira, 2010, pp. 330-331.

${ }^{89}$ GILSON, Étienne. O espírito da filosofia medieval. Op. cit. pp., 372-373.

${ }^{90}$ FERRAZ JR., Tercio Sampaio. Estudos de filosofia do direito. Op. cit., p. 88: "A liberdade instala-se no interior da vontade. Dito de outra maneira: a vontade como opção (quer/não quer) é livre, e nisso consiste a liberdade".
} 
o embate entre querer e não querer (velle et nolle), inerente à faculdade de escolha, não consiste em um conflito entre mente e vontade, ou entre corpo e alma, mas numa luta que se trava no interior da própria vontade ${ }^{91}$. Em suas Confissões, Santo Agostinho descreveu muito bem essa luta que lhe dilacerava a alma ${ }^{92}$; atormentava-o a perplexidade de uma vontade divida contra si mesma: "a alma ordena que queira - por que se não quisesse não mandaria -, e não executa aquilo que manda"93. Agostinho não chega a encontrar uma solução para esse problema, um problema que, segundo entendemos, nunca deixou de estar presente nas discussões sobre a liberdade ${ }^{94}$.

De todo modo, a primeira grande consequência da distinção trazida por São Paulo é a assunção da seguinte ideia: não se pode dizer de uma vontade qualquer que ela não é livre; toda vontade é necessariamente livre, pois, se é possível constranger um homem a fazer uma coisa, não é possível obrigá-lo a querer fazê-la ${ }^{95}$. Assim, somente é passível de limitação o exercício do ato livre, pois a liberdade de querer, que nós chamamos de vontade, essa não se pode limitar. Nesse específico sentido de liberdade, aliás, todos os homens são livres, porque mesmo o mais escravo dos homens é livre em sua vontade. E, do mesmo modo, todos os homens são moralmente responsáveis, pois toda vontade, quando deseja, poderia não ter desejado. Portanto, daquela distinção pauliana decorrem tanto um fundamento razoável da igualdade entre os homens, quanto uma importante base para a responsabilidade ética individual. Os homens são iguais em essência, porque igualmente livres em seu querer, mas são acidentalmente diferentes, porquanto nem todos podem o que querem.

No entanto, a ideia judaico-cristã de livre-arbítrio sempre esbarrou nas implicações de se crer num Criador onipotente e onisciente. Se nada acontece sem que o Criador o permita, e se Ele já conhece, de antemão, o que os homens hão de querer ou fazer, como é possível acreditar na liberdade dos seres humanos? Ou, dito de outro modo: Se a crença num Deus todo-poderoso nos remete à ideia de um futuro necessário, e se a crença na liberdade humana nos remete à ideia de futuros apenas possíveis - dado que os

\footnotetext{
${ }^{91}$ LAFER, Celso. Hannah Arendt: pensamento, persuasão e poder. Op. cit., p. 92. Ver também, ARENDT, Hannah. $A$ vida do espírito... Op. cit., p. 357.

92 SANTO AGOSTINHO. Confissões. Traduzido por Oliveira Santos, S.J. e A. Ambrósio de Pina, S.J.. São Paulo: Editora Nova Cultural, 1999, pp. 209-211 e pp. 214-220.

${ }^{93}$ SANTO AGOSTINHO. Confissões. Op. cit., p. 217.

${ }^{94}$ ARENDT, Hannah. A vida do espírito... Op. cit., p. 359.

${ }^{95}$ GILSON, Étienne. O espírito da filosofia medieval. Op. cit. pp., 373-374. Também, ARENDT, Hannah. $A$ vida do espírito... Op. cit., p. 275: "Uma vontade que não é livre é uma contradição em termos".
} 
indivíduos podem sempre decidir entre vários atos voluntários - como é possível conciliar as duas crenças? Os filósofos da Idade Média debruçaram-se sobre tal aporia e tentaram de diversas formas compatibilizar essas duas convicções. É verdade que eles tinham sido precedidos pelos estoicos e estes, com a afirmação de que a verdade somente poderia ser encontrada "na aceitação voluntária da ordem universal" 96 , já lhes indicavam uma tentativa de harmonizar tais crenças. Éttiene Gilson nos mostra, em seu estudo, que, apesar das inúmeras teorias medievais que buscavam resolver tal perplexidade, ela se manteve irresolúvel até o advento da Era Moderna, quando deixou de ser uma preocupação central para os pensadores. Como não há espaço aqui para tratarmos dessas teorias, remetemos o leitor para o trabalho de Gilson e o esclarecedor resumo que ele faz dessa problemática ${ }^{97}$.

A noção de livre-arbítrio - essa liberdade essencial instalada no interior da vontade - logo se mostrou relevante para o presente estudo, por se tratar de um ponto para o qual convergem reflexões fundamentais acerca da liberdade.

Em primeiro lugar, essa noção tornou clara a dificuldade de se compreender como uma vontade cindida entre um querer e um não querer pode ser livre. Ao colocar a vontade livre no centro das discussões éticas, tornou-se premente saber se a vontade é sempre livre. Uma vontade aparentemente irracional ou injusta pode ser considerada livre? De que modo a formação da vontade influencia em sua liberdade? Com efeito, as discussões sobre o paternalismo, em regra, acabam sempre por retomar tais indagações sobre o problema da vontade livre. Como vimos, no centro das justificações de posturas paternalistas, há sempre argumentos a revelar alguma forma de debilidade da vontade ou de sua expressão.

Em segundo lugar, a dificuldade em se resolver o antagonismo entre livrearbítrio e predestinação tornou-se um problema presente em todas as correntes filosóficas que, influenciadas pela tradição iluminista, buscaram teorizar sobre as melhores formas de organização estatal. Todas elas enfrentaram problemas para administrar esse antagonismo, o qual se lhes apresentou sob a forma de um conflito que opõe os dois mais fortes ideais iluministas: o ideal de busca das verdades necessárias pela ciência (necessidade) e o ideal

\footnotetext{
${ }^{96}$ GILSON, Étienne. O espírito da filosofia medieval. Op. cit., p. 376.

97 GILSON, Étienne. O espirito da filosofia medieval. Op. cit., pp. 367-393. Também Hannah Arendt oferece-nos um estudo de fôlego sobre esse esforço dos filósofos medievais. Trata-se de um trabalho imprescindível, especialmente pela erudição com que trata dos universos intelectuais de Agostinho, Tomás de Aquino e Duns Scotus. Veja-se ARENDT, Hannah. A vida do espírito... Op. cit., pp. 326-411.
} 
de proteção das liberdades individuais por meio do reconhecimento de direitos humanos fundamentais.

\subsubsection{3 - A liberdade moderna}

Há mais uma razão para considerarmos relevante, no âmbito deste estudo, o conceito de liberdade como livre-arbítrio. É que ele prepara o caminho para a ideia, que viria mais tarde, de "liberdade de exercício como ausência de coação": a ideia de que "nem o soberano, nem o Estado, pode constranger a liberdade, só seu exercício" "98. Assim, passa a preponderar o conceito de liberdade como ausência de obstáculos ou impedimentos - da qual mesmo Hobbes, um autor comumente associado à defesa do absolutismo, compartilha 99 . Ao definir o homem livre como aquele que "não é impedido de fazer o que tem vontade de fazer" ${ }^{\prime 100}$, a reflexão dos modernos sobre a liberdade parece não pôr em dúvida a liberdade inerente à vontade. Na verdade, no centro dessa reflexão está não a dúvida sobre a natureza da vontade, mas a preocupação com os obstáculos que impedem o exercício do ato voluntário.

Assim, os que defendem essa concepção moderna de liberdade entendem que um indivíduo qualquer é tão mais livre quanto menor for a interferência alheia em sua vida. Nesse diapasão, os autores liberais passam a entender a luta pela liberdade como a luta pela liberdade de exercício. Conforme se observa, a reflexão moderna em torno desse conceito não mais associa o termo liberdade à ideia de um ordenamento normativo autonomamente consentido, mas à esfera da não-interferência ${ }^{101}$.

\footnotetext{
${ }^{98}$ FERRAZ JR., Tercio Sampaio. Estudos de filosofia do direito. Op. cit., p. 91.

99 "Liberdade, ou Independência significa, em seu sentido próprio, a ausência de oposição (entendendo por oposição os impedimentos externos do movimento)". HOBBES, Thomas. Leviatã ou Matéria, forma e poder de um estado eclesiástico e civil. Organizado por Richard Tuck; traduzido por João Paulo Monteiro e Maria Beatriz Nizza da Silva; tradução revisada por Eunice Ostrensky. São Paulo: Martins Fontes, 2008 (Clássicos Cambridge de filosofia política), p. 179. Também, LAFER, Celso. "O moderno e o antigo conceito de liberdade". Op. cit., p. 18.

${ }^{100}$ HOBBES, Thomas. Leviatã... Op. cit., p. 179.

${ }^{101}$ LAFER, Celso. "O moderno e o antigo conceito de liberdade". Op. cit., pp. 18-22.
} 


\subsection{2 - Limitação do poder}

Quando escreveu "Da liberdade dos modernos comparada à dos pósteros"102, Bobbio tencionava refutar a suposta incompatibilidade entre democracia e liberalismo que Galvano Della Volpe afirmava em sua crítica à democracia liberal ${ }^{103}$.

Para desempenhar essa tarefa, Bobbio buscou demonstrar que, no cerne da doutrina do Estado liberal ${ }^{104}$, está a defesa do Estado limitado. Segundo Bobbio, "toda a história do Estado liberal desenvolve-se através da busca de técnicas aptas a realizar o princípio da limitação do poder"105. Para Bobbio, as duas mais importantes técnicas de limitação do poder estatal, criadas (conquistadas) pela doutrina do Estado liberal, foram a proclamação de direitos fundamentais e a divisão de poderes. Bobbio as denomina limitações material e formal do poder:

Podem-se distinguir, para maior clareza, duas formas de limitação do poder: uma limitação material, que consiste em subtrair aos imperativos positivos e negativos do soberano uma esfera de comportamentos humanos que são reconhecidos livres por natureza (a chamada esfera da licitude); e uma limitação formal, que consiste em colocar todos os órgãos do poder estatal abaixo das leis gerais do mesmo Estado. A primeira limitação está fundada no princípio da garantia dos direitos individuais por parte dos poderes públicos; a segunda, no controle dos poderes públicos por parte dos indivíduos. Garantia dos direitos e controle dos poderes são os traços característicos do Estado liberal. O primeiro dos princípios deu origem à proclamação dos direitos naturais; o segundo, à divisão dos poderes ${ }^{106}$.

\footnotetext{
${ }^{102} \mathrm{O}$ texto foi publicado em 1954 e está reunido a outros ensaios em BOBBIO, Norberto. "Da liberdade dos modernos comparada à dos pósteros". In: Teoria geral da política: a filosofia e as lições dos clássicos. Organizado por Michelangelo Bovero; traduzido por Daniela Beccaccia Versiani. 2. ed. Rio de Janeiro: Ed. Campus, 2000, pp. 269-297. Seu título irônico faz óbvia alusão ao título do discurso proferido por Constant. ${ }^{103}$ VOLPE, Galvano Della. "Il problema della liberta egualitaria nello svilupo della Moderna Democrazia". In: D'ENTRÈVES, Alessandro Passérin (organizador). La libertà politica. Edizioni di Comunità, 1974, pp. 55-66.

${ }^{104}$ Para um estudo sobre a evolução da doutrina liberal, remeto o leitor ao excelente MERQUIOR, José Guilherme. O liberalismo - antigo e moderno. Traduzido por Henrique de Araújo Mesquita. 2. Ed. Rio de Janeiro: Ed. Nova Fronteira, 1991.

${ }_{105}$ BOBBIO, Norberto. Teoria geral da política... Op. cit., p. 276.

${ }^{106}$ BOBBIO, Norberto. Teoria geral da política... Op. cit., p. 276. No início de seu ensaio A liberdade, Mill já fazia referência a esses dois modos de se limitar a liberdade. MILL, John Stuart. A liberdade / Utilitarismo. Op. cit., pp. 05-07.
} 
Sob uma observação superficial, essa distinção entre formas de se limitar o poder estatal bem poderia parecer, pura e simplesmente, um reflexo da distinção entre os significados antigo e moderno de liberdade.

A limitação material, que, como Bobbio diz, estabelece uma esfera de comportamentos reconhecidamente livres, não passaria, sob esse prisma, de uma forma de se garantir a liberdade em seu sentido moderno (liberdade como não-impedimento): quanto maior a limitação material, maior o grau de liberdade, tal como concebida pelos modernos. Já a limitação formal, centrada que está, como afirma Bobbio, no controle do poder pelos indivíduos, seria apenas uma outra forma de propiciar a liberdade em seu sentido antigo (liberdade como autonomia).

Engana-se, porém, quem compreendeu desse modo tal distinção. Apesar dessa inicial obscuridade, não há espaço para dúvidas: ao se referir à divisão de poderes, como instituto que surgiu da limitação formal, fica claro que, para Bobbio, "controle dos poderes públicos por parte dos indivíduos" não é o mesmo que "detenção" do poder pelos indivíduos. Tal como a limitação material, portanto, a limitação formal é uma técnica por meio da qual se combate o poder absoluto e não de uma técnica para o exercício do poder.

O intuito de ressaltar essa possível interpretação, no entanto, é o de se antecipar a habituais confusões. A ideia de limitação do poder foi (e ainda é), com frequência, expressa em termos de seu controle ou repartição. Evitam-se os abusos de poder, controlando-o - mas quem controla o poder, de certa forma, também o detém. Por isso, evitam-se os abusos de poder repartindo-o entre muitos, para que ninguém detenha o poder absoluto. Cada braço do Estado exerce uma parte do poder na produção e aplicação das leis (doutrina da separação). Cada cidadão exerce uma parte do poder, por exemplo, na escolha plebiscitária (doutrina democrática). Pelo menos num primeiro olhar, ninguém negaria que essas técnicas são meios para a limitação do poder. Mas a ideia de limitação do poder, pelo seu controle ou compartilhamento, não sem alguma licenciosidade, foi por vezes vinculada a noções de liberdade ${ }^{107}$ e, nesse ponto, antecipa-se uma acusação que logo estudaremos melhor: o conceito de liberdade dos antigos às vezes parece menos

\footnotetext{
${ }^{107}$ O próprio Bobbio reconhece as "difíceis e controvertidas relações entre as duas exigências fundamentais de que nasceram os Estados contemporâneos nos países econômica e socialmente mais desenvolvidos: a exigência, de um lado, de limitar o poder e, de outro, de distribui-lo". BOBBIO, Norberto. Liberalismo e democracia. Tradução de Marco Aurélio Nogueira. 6. ed. São Paulo: Brasiliense, 2006, p. 08.
} 
atrelado às veleidades emancipatórias de autogoverno que à preocupação - talvez, menos nobre - de distribuir o poder.

Na verdade, Bobbio assevera que os dois usos diversos da palavra liberdade entram em jogo quando se fala da relação entre a doutrina democrática e a limitação material do Estado. É na discussão sobre o Estado materialmente limitado - e sua possível incompatibilidade com o ideal democrático - que surge a necessidade de se delinear bem a diferença entre os significados. Pelo menos, "se não desejamos perpetuar as confusões que caracterizam a linguagem política" ${ }^{, 108}$.

Desse modo, na linha da distinção traçada por Benjamin Constant, Bobbio afirma que o significado moderno de liberdade é aquele defendido pela doutrina liberal e com o qual se quer indicar um "estado de não-impedimento", uma esfera no interior da qual não há ações proibidas ou obrigatórias, mas apenas permitidas. A doutrina liberal do Estado caracteriza-se por exigir uma diminuição da esfera de condutas obrigatórias (ou proibidas) e uma ampliação da esfera de condutas permitidas. De outro giro, a liberdade em seu sentido antigo é aquela defendida pela doutrina democrática e com a qual se quer indicar o poder de estabelecer normas para si próprio, o poder de somente a tais normas obedecer: liberdade nesse sentido, como já se salientou anteriormente, é autonomia.

Para Norberto Bobbio, o primeiro significado de liberdade (moderno) opõese à ideia de "impedimento", enquanto o segundo (antigo) opõe-se à ideia de "coerção". Também segundo Bobbio, tais significados são mais bem acompanhados, respectivamente, pelos termos "ação" e "vontade", de modo que uma ação livre é justamente uma ação não impedida, ao passo que uma vontade livre é justamente aquela que se autodetermina ${ }^{109}$.

Assim, como já o fizera Constant, Norberto Bobbio vincula, de maneira clara, a liberdade como não-impedimento à doutrina liberal e a liberdade como autonomia à doutrina democrática. No entanto, insiste na igual legitimidade de ambos os significados: "E ai de quem se embrenhar na discussão sobre qual das duas liberdades seja a verdadeira liberdade" $" 110$. A discussão sobre qual é a verdadeira liberdade é tão vã quanto aquela sobre

\footnotetext{
${ }^{108}$ BOBBIO, Norberto. Teoria geral da política... Op. cit., p. 279.

${ }^{109}$ BOBBIO, Norberto. Teoria geral da política... Op. cit., p. 280.

${ }^{110}$ BOBBIO, Norberto. Teoria geral da política... Op. cit., p. 280.
} 
qual delas é a melhor: ambos os sentidos indicam estados desejáveis para os seres humanos $^{111}$.

Para ele, o equívoco de se acreditar na existência da verdadeira (ou melhor) liberdade pode ser às vezes pernicioso. Assim, por exemplo, a certa altura de nossa história moderna, verificou-se a dificuldade de se realizar satisfatoriamente a liberdade como nãoimpedimento. O Estado se apresentava cada vez mais invasivo, a ponto de as limitações à esfera de ação individual parecerem inevitáveis. Logo se percebeu que a noção de liberdade como autonomia perecia resolver esse problema com presteza: não era mais preciso combater as limitações impostas pelo Estado; bastava que elas fossem, o mais possível, autolimitações ${ }^{112}$. Além disso, a liberdade moderna parecia menos necessária naquele momento em que o governo de poucos tinha dado lugar ao governo de muitos. Portanto, como se vê, o equívoco de se buscar a verdadeira liberdade é perigoso, não porque dá azo a disputas ideológicas infundadas, mas porque sugere a possibilidade de nos agarrarmos a uma, descartando a outra.

\subsection{3 - Dificuldades do autogoverno}

Se é difícil propiciar a liberdade liberal de maneira satisfatória, melhor sorte não tem a liberdade democrática. Porque, em nossos dias, a autonomia com que ela se preocupa só é tecnicamente realizável com a mediação de representantes (governo representativo) e com uma regra para apuração das propostas vencedoras (princípio majoritário). Ora, quando quem decide não sou eu, mas a maioria - ou quando quem decide não sou eu, mas meus representantes -, o melhor que se pode dizer de minha autonomia, nessas situações, é que ela se torna menos óbvia. Não por outro motivo, Bobbio põe em dúvida que seja possível falar em autonomia no caso da decisão majoritária ${ }^{113}$. Mas, se decisões tomadas por representantes com base na regra da maioria são a única

\footnotetext{
${ }^{111}$ A despeito de seu significado descritivo ambíguo, o termo liberdade tem um significado apreciativo nãoambíguo, a indicar uma situação altamente desejável para qualquer pessoa. BOBBIO, Norberto. Teoria geral da politica: a filosofia e as lições dos clássicos. Op. cit., pp. 280. Também LAFER, Celso. "O moderno e o antigo conceito de liberdade". In: Ensaios sobre a liberdade. São Paulo: Ed. Perspectiva, 1980, p. 14.

${ }_{112}$ BOBBIO, Norberto. Teoria geral da politica... Op. cit., pp. 280-282.

${ }^{113}$ BOBBIO, Norberto. Teoria geral da política... Op. cit., p. 282: "E se ainda tem algum sentido falar de autonomia no caso da vontade da maioria, com que fundamento é possível falar de uma vontade autônoma a propósito da minoria se ela é obrigada pelos princípios do mesmo sistema a conformar-se com as decisões dos muitos?".
} 
forma de se realizar o ideal democrático - de um modo que a autonomia garantida se torna menos real que hipotética -, então os fautores da liberdade democrática têm menos razões para condenar como despiciendas as preocupações com a liberdade em seu sentido moderno $^{114}$.

Além disso, como já se afirmou, um indivíduo é autônomo quando obedece a leis cuja criação ele próprio desejou. Mas, como se pode garantir que os desejos sejam livremente comunicados? A resposta, para Bobbio, está na liberdade como nãoimpedimento: "para que os desejos dos cidadãos sejam conhecidos, é necessário que o maior número possível deles possa se expressar livremente"115. O indivíduo que se dirige às urnas deve gozar "das liberdades de opinião, de imprensa, de reunião, de associação, de todas as liberdades que constituem a essência do Estado liberal, (...) para que a participação seja real e não fictícia"116.

Nesse ponto, Norberto Bobbio parece nos ensinar que as liberdades como não-impedimento têm a função de garantir que o indivíduo expressará livremente sua vontade, por ocasião das votações - nas eleições ou no parlamento -, e que tal vontade será livremente formada ${ }^{117}$. Só assim podemos entender por que, para Bobbio, "a própria vontade como autonomia pressupõe uma situação de liberdade como não-impedimento"118. Livre expressão e livre formação da vontade são exigências que nos remetem à clássica discussão sobre os vícios de consentimento. Mesmo os entusiastas - defensores "até as últimas consequências", para falar como Bobbio - da liberdade democrática têm apreço por essas exigências. Sabem que, de alguma forma, elas são importantes para aquilo que entendem ser a verdadeira liberdade. Não podem, bem por isso, abdicar impunemente da liberdade liberal.

\footnotetext{
${ }_{114}^{114}$ BOBBIO, Norberto. Teoria geral da política... Op. cit., pp. 282-283.

${ }^{115}$ BOBBIO, Norberto. Teoria geral da política... Op. cit., p. 283. Constant já havia apontado a insuficiência da liberdade dos antigos: "O perigo da liberdade antiga estava em que, atentos unicamente à necessidade de garantir a participação no poder social, os homens não se preocupassem com os direitos e garantias individuais", CONSTANT, Benjamin. "Da liberdade dos antigos...". Op. Cit., p. 06.

${ }^{116}$ BOBBIO, Norberto. Liberalismo e democracia. Op. cit., p. 44.

${ }^{117}$ Voltaremos ao problema da livre vontade em 2.2.3.

${ }^{118}$ BOBBIO, Norberto. Teoria geral da política: a filosofia e as lições dos clássicos. Op. cit., p. 282.
} 


\subsection{4 - Democracia e liberalismo: origem no individualismo}

Fica claro, portanto, que, para Bobbio, o convívio entre a liberdade democrática e a liberdade liberal não é apenas possível, mas faz-se particularmente necessário. Em sua obra Liberalismo e Democracia, ele nos propõe uma explicação para essa mútua dependência. Ela repousa no fato de que democracia e liberalismo têm, ambos, uma origem comum: a concepção individualista da sociedade ${ }^{119}$.

De fato, ao contrário do organicismo, que considera o Estado uma totalidade anterior e superior aos indivíduos - e em função da qual eles vivem -, o individualismo considera o Estado como resultado das atividades exercidas pelos indivíduos e das relações por eles estabelecidas ${ }^{120}$. Daí o empenho liberal em proteger o indivíduo dos excessos da atividade estatal, buscando limitá-la tanto em seu poder (Estado de direito), quanto em suas funções (Estado mínimo) ${ }^{121}$. Daí o empenho dos democratas em ampliar a participação do indivíduo na tomada de decisões estatais.

É claro, diz Bobbio, que o indivíduo protegido pelo liberalismo é diferente daquele defendido pela democracia. De uma forma bastante sintética, podemos dizer que o primeiro é o indivíduo voltado para seu próprio interior, protagonista de atividades desenvolvidas fora do Estado, enquanto o segundo é o que se volta para o exterior e atua no seio da própria atividade estatal ${ }^{122}$. Ou, dizendo de outro modo: liberalismo e democracia protegem dois aspectos diversos de um mesmo indivíduo, o que ajuda a explicar, ainda uma vez, porque são ideais que se complementam. Para Norberto Bobbio, a experiência contemporânea corrobora essa ideia quando demonstra que os ideais liberais e o método democrático a tal ponto tornaram-se irmãos que hoje “apenas os Estados nascidos das revoluções liberais são democráticos e apenas os Estados democráticos protegem os direitos do homem"123. Ou seja, a evolução dos Estados modernos exigiu a integração das duas liberdades, traduzida na seguinte fórmula: é necessário ampliar a liberdade como não-impedimento (liberdade liberal) até onde seja possível e, onde isso já não for mais possível, cumpre a aumentar a liberdade coletiva (liberdade democrática) ${ }^{124}$.

\footnotetext{
${ }^{119}$ BOBBIO, Norberto. Liberalismo e democracia. Op. cit., p. 45.

${ }^{120}$ BOBBIO, Norberto. Liberalismo e democracia. Op. cit., p. 45-46.

${ }^{121}$ BOBBIO, Norberto. Liberalismo e democracia. Op. cit., p. 17.

${ }^{122}$ BOBBIO, Norberto. Liberalismo e democracia. Op. cit., p. 47-48.

${ }^{123}$ BOBBIO, Norberto. Liberalismo e democracia. Op. cit., p. 44.

${ }^{124}$ BOBBIO, Norberto "Kant e as duas liberdades". In: Teoria geral da política. Op. cit, p. 101-103.
} 
Ou, nas palavras de Bobbio: "aquilo que o homem é capaz de decidir sozinho, que seja deixado à livre determinação do seu querer; lá onde é necessária uma decisão coletiva, que ele participe de modo que também esta seja ou pareça ser uma livre determinação de seu querer" 125 .

Essa intrincada relação entre liberdade liberal e liberdade democrática ajuda-nos a entender por que Stuart Mill foi, a um só tempo, liberal e democrata. Segundo Bobbio, Stuart Mill considerava a democracia como o "natural e consequente desenvolvimento dos princípios liberais" ${ }^{\prime 26}$. Mill sabia que a democracia oferecia riscos para a liberdade. Mas sua confiança na ligação necessária entre democracia e liberdade individual fez que ele buscasse com mais empenho os remédios para os possíveis males. A elaboração de seu princípio do dano - não há como negar - é o fruto mais virtuoso desse empenho.

\subsection{5 - Regra da maioria: uma norma secundária}

Por uma exigência de rigor que ele muito estimava, no campo da teoria do direito, Bobbio optou pelo positivismo jurídico ou, mais precisamente, por um normativismo bem próximo, em alguns pontos, daquele ensinado por Hans Kelsen. Essa postura que Bobbio assumiu em seu papel de jusfilósofo estava, logo se viu, em completa sintonia com as grandes questões que o preocupavam no campo da filosofia política. A sua preocupação com a liberdade não foge a essa regra: como bem afirmou Celso Lafer a respeito de Bobbio, "seu normativismo está a serviço da causa da liberdade"127. Realmente, Bobbio com acuidade observou que o Estado liberal é, acima de tudo, o Estado de direito; técnica jurídica e princípios liberais convergem quando se trata de controlar o exercício do $\operatorname{poder}^{128}$.

Na mesma linha, está sua defesa da democracia enquanto defesa das regras do jogo. Em uma influente obra, Bobbio arrola argumentos que têm sido usados em prol da

\footnotetext{
${ }^{125}$ BOBBIO, Norberto "Kant e as duas liberdades”. In: Teoria geral da politica. Op. cit., p. 103.

${ }^{126}$ BOBBIO, Norberto. Liberalismo e democracia. Op. cit., p. 62.

${ }^{127}$ LAFER, Celso. "Filosofia do direito e filosofia política - notas sobre a defesa da liberdade no percurso intelectual de Norberto Bobbio". In: Ensaios sobre a liberdade. São Paulo: Ed. Perspectiva, 1980, p. 60.

${ }^{128}$ LAFER, Celso. "Filosofia do direito e filosofia política - notas sobre a defesa da liberdade no percurso intelectual de Norberto Bobbio". Op. cit., p. 61.
} 
democracia. Segundo ele, a preferência pela democracia ao longo da história pode ser explicada sob diversas perspectivas, nomeadamente as perspectivas ética, política e utilitária. Sob uma perspectiva ética, a democracia tende a ampliar a realização da autonomia na esfera política, isto é, na esfera em que são tomadas decisões para toda a coletividade. Politicamente, o principal argumento em favor da democracia é o fato de ser ela um dos mais importantes remédios contra o abuso do poder. $\mathrm{O}$ argumento utilitário, por fim, é aquele segundo o qual não há melhores intérpretes do interesse coletivo do que os próprios interessados $^{129}$.

Além desses - talvez nem seja necessário dizer -, há o robusto argumento de que temos falado ao longo deste capítulo e que é particularmente importante para todos os fautores dos princípios liberais: a ideia de que a democracia é o aperfeiçoamento dos ideais liberais, o método que melhor protege as liberdades individuais.

Mas, qual o papel do normativismo bobbiano em tal contexto? Nesse particular, é extremamente relevante a observação feita por Celso Lafer, num ensaio em que expõe a defesa da liberdade no percurso intelectual de Bobbio. Não passou despercebido a Lafer o fato de que a ênfase dada por Bobbio, na teoria do direito, às chamadas normas secundárias, está diretamente ligada à defesa e proteção da liberdade ${ }^{130}$. Essa observação merece um exame mais detido.

Sabemos que Norberto Bobbio classifica as normas jurídicas em normas de comportamento, que podemos chamar de normas primárias e normas de estrutura, que podemos chamar de secundárias. Segundo ele, normas primárias são aquelas que tratam diretamente das condutas humanas: são normas que prescrevem, proíbem ou permitem condutas. Por sua vez, secundárias são as normas que tratam da produção e aplicação de normas primárias: são normas sobre normas. Assim, uma norma que proíbe o homicídio ou uma que torna obrigatório o alistamento militar são normas primárias (a primeira proscreve e a segunda torna compulsórias condutas específicas). Por outro lado, normas sobre processo legislativo ou normas de processo civil, por exemplo, são secundárias, porque

\footnotetext{
129 BOBBIO, Norberto. Qual socialismo? - Debate sobre uma alternativa. Traduzido por Iza de Salles Freaza. Rio de Janeiro: Paz e Terra, 1983 (Coleção Pensamento Crítico, v. 52), pp. 84-85.

${ }^{130}$ LAFER, Celso. "Filosofia do direito e filosofia política - notas sobre a defesa da liberdade no percurso intelectual de Norberto Bobbio". In: Ensaios sobre a liberdade. Op. cit., p. 74.
} 
estabelecem, respectivamente, o processo de criação de normas primárias e o modo de sua aplicação por autoridades competentes ${ }^{131}$.

Ora, se democrático é o "sistema de poder no qual as decisões coletivas, isto é, as decisões que interessam a toda a coletividade (grande ou pequena que seja), são tomadas por todos os membros que a compõem"132, isso implica alguma forma de participação dos indivíduos na produção das normas às quais se submeterão. Nesses termos, a diferença da democracia em relação a outros sistemas está, justamente, no seu processo de nomogênese - na democracia, a produção das normas jurídicas (e, em certo sentido, do direito) é condicionada por um processo que tende a ampliar a autonomia dos indivíduos. Nessa linha, portanto, as normas secundárias têm papel fundamental na ampliação da liberdade (pelo menos da liberdade enquanto autonomia). O leitor já deve ter observado que a regra da maioria é precisamente uma norma desse tipo, uma norma secundária. Celso Campilongo já sugeriu que a regra da maioria poderia ser estudada, no âmbito da teoria geral do direito, como uma espécie de regra secundária. Para ele, a regra da maioria poderia ser considerada "uma regra secundária de câmbio que aumentaria o dinamismo das transformações no ordenamento jurídico" $" 133$ - aqui Campilongo traz expressa referência a Herbert L. A. Hart, autor de $O$ conceito de direito.

Aqueles que estão de algum modo familiarizados com a teoria geral do direito, ensinada há um século, certamente concordarão que a distinção técnica entre normas primárias e secundárias aproxima sobremaneira Bobbio de outra importante figura do pensamento jusfilosófico do século XX, o professor Herbert Hart, que descreveu o direito como a união entre normas primárias (normas de conduta) e normas secundárias (normas sobre normas). Com efeito, a teoria de Hart distinguia três espécies de normas secundárias: normas de reconhecimento (que possibilitam identificar as normas de conduta pertinentes ao ordenamento), normas de modificação - ou de câmbio - (que possibilitam a introdução de novas normas primárias no ordenamento) e normas de julgamento (normas

\footnotetext{
${ }^{131}$ BOBBIO, Norberto. Teoria do ordenamento jurídico. Tradução de Maria Celeste Cordeiro dos Santos. 10. ed. Brasília: Editora Universidade de Brasília, 1999, pp. 33-34 e pp. 45-47.

${ }^{132}$ BOBBIO, Norberto. Qual socialismo? Op. cit., p. 80.

${ }^{133}$ CAMPILONGO, Celso Fernandes. Direito e Democracia. 2. ed. Editora Max Limonad, 2000, p. 19.
} 
que capacitam determinados indivíduos ou grupos a solucionarem o problema de saber, no caso concreto, se uma norma de conduta foi infringida) ${ }^{134}$.

Hart foi explícito ao se referir às normas secundárias como um tipo de conquista inerente à passagem de uma sociedade simples para uma sociedade complexa. A afirmação de que o direito pode ser modificado deliberadamente é corroborada pela existência de normas que preveem meios para a alteração deliberada do ordenamento jurídico (normas secundárias de modificação). Para Hart, essa possibilidade é um dos caracteres que diferenciam as normas jurídicas das normas morais, pois estas não são suscetíveis de modificação deliberada ${ }^{135}$. Tal possibilidade indica também a passagem de uma sociedade pré-jurídica, na qual as normas primárias são a única forma de controle social, para o mundo jurídico, “com seu poder legislativo, tribunais, autoridades e sanções

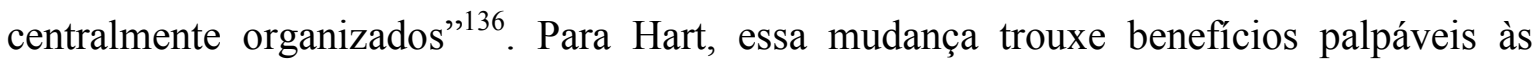
sociedades ${ }^{137} \mathrm{e}$, no caso específico das normas de modificação, a vantagem mais explícita é a "adaptabilidade às mudanças"138.

É importante sublinhar o alcance das ponderações de Hart sobre a ideia de mudança deliberada como marca que diferencia o direito das normas morais. Jeremy Waldron afirma que os teóricos contemporâneos da ciência jurídica subestimaram esse alcance. Para Waldron, a teoria de Hart contribui ainda hoje para ressaltar o valor da legislação, pois ensina que "uma sociedade pode desenvolver práticas cuja tarefa é governar os processos pelos quais as regras e as práticas de primeiro nível podem ser modificadas" $" 139$.

Pois bem. Toda essa digressão sobre as chamadas normas secundárias nos serve de base para a afirmação de que a regra majoritária, enquanto norma secundária de modificação, pode ser vista como um tipo de conquista que vai além da adaptabilidade às

\footnotetext{
${ }^{134}$ HART, Herbert L. A.. O conceito de direito. Traduzido por Antonio de Oliveira Sette-Câmara; pós-escrito e organizado por Penelope A. Bulloch e Joseph Raz. São Paulo: Editora WMF Martins Fontes, 2009, pp. 122-126.

${ }^{135}$ HART, Herbert L. A.. O conceito de direito. Op. cit., p. 227.

${ }^{136}$ HART, Herbert L. A.. O conceito de direito. Op. cit., 261.

${ }^{137}$ HART, Herbert L. A.. O conceito de direito. Op. cit., p. 261. Mas Hart reconhece que essa mudança também traz riscos. Ibidem. Veja-se, também, WALDRON, Jeremy. A Dignidade da Legislação. Traduzido por Luís Carlos Borges. São Paulo: Martins Fontes, 2003, p. 17.

${ }^{138}$ HART, Herbert L. A.. O conceito de direito. Op. cit., p. 261.

${ }^{139}$ WALDRON, Jeremy. A Dignidade da Legislação. Op. cit., p. 24.
} 
mudanças sociais: uma conquista associada ao igual respeito que se deve dispensar às diferentes opiniões no seio da sociedade e à liberdade de cada indivíduo.

Bobbio não descreveu as normas secundárias como uma forma de conquista. Ainda assim, não nos parece absurdo afirmar que sua teoria do direito - na qual o enfoque positivista está em clara harmonia com a defesa da liberdade empreendida na teoria política - tem mais a dizer sobre a importância do princípio majoritário do que parece à primeira vista.

\section{2 - As lições de Isaiah Berlin}

Tal como Benjamin Constant e Norberto Bobbio, Isaiah Berlin também entende que a liberdade dos antigos é a liberdade vista como autonomia e que a liberdade dos modernos é a liberdade enquanto ausência de obstáculos para a ação individual. Mas Isaiah Berlin acrescenta algo. Para Berlin, a liberdade dos antigos, por ele denominada liberdade positiva, relaciona-se com a resposta à pergunta: “Por quem sou governado?”. Já a liberdade em seu sentido moderno, que ele chamou liberdade negativa, está implicada na resposta à pergunta: "Qual o grau de interferência alheia em minha vida?"140.

Em escrito posterior, Berlin também acrescenta um esclarecimento em relação ao que deve ser entendido por liberdade negativa: “A extensão de minha liberdade social e política consiste na ausência de obstáculos não simplesmente a minhas escolhas reais, mas também a minhas escolhas potenciais" ${ }^{\prime 41}$. Para esse autor, se liberdade fosse simplesmente a ausência de impedimentos à satisfação de desejos, então bastaria que o indivíduo renunciasse a seus desejos para tornar-se livre (tal como o ideal estoico).

Embora sua descrição dos conceitos de liberdade coincida, em muitos aspectos, com a descrição feita por Bobbio, o ensaio de Isaiah Berlin - "Dois conceitos de liberdade" - oferece-nos uma gama de ideias novas e profundas sobre aqueles conceitos. Conforme já se afirmou no início deste capítulo, Berlin não atribui o mesmo valor a essas duas acepções do termo "liberdade". Nesse ensaio, a cada passo de sua exposição, Berlin

\footnotetext{
${ }^{140}$ BERLIN, Isaiah. Estudos sobre a humanidade... Op. cit., pp. 228-229.

${ }^{141}$ BERLIN, Isaiah. "Introdução". In: Quatro ensaios sobre a liberdade. Traduzido por Wamberto Hudson Ferreira. Brasília: Editora Universidade de Brasília, 1981 (Coleção Pensamento Político, nº 39), p. 21.
} 
nos dá a impressão de que está prestes a negar o status de liberdade ao sentido "positivo" do termo e a dizer, triunfante, que somente a liberdade dos modernos é digna do nome. Todavia, ele não chega a afirmá-lo expressamente. Tal como faz em outro de seus escritos, Berlin apenas insinua esse entendimento ${ }^{142}$.

De todo modo, nesse ensaio, há três afirmações cuidadosamente desenvolvidas que, por sua importante contribuição, merecem uma análise mais detida. A primeira é a afirmação de que não existe relação necessária entre liberalismo e democracia, como não há, ao contrário do que afirma Bobbio, entre a liberdade negativa (liberal) e os valores democráticos. A segunda é a afirmação de que a liberdade positiva se presta a confusões que podem levar a uma postura despótica. A terceira é a afirmação de que, precisamente por isso, a liberdade negativa é mais consentânea com os valores do pluralismo e com o reconhecimento da falibilidade humana.

Nas próximas páginas, veremos como Isaiah Berlin desenvolveu essas ideias.

\subsection{1 - A liberdade negativa}

Um sujeito é livre na medida em que não o impedem de fazer o que ele quer, na medida em que não interferem em suas ações. Os pensadores que compreenderam a liberdade dessa forma sabiam que ela não pode ser ilimitada. Se fosse, "todos os homens poderiam interferir ilimitadamente na vida de todos os outros homens"143. Sabiam, pois, que era necessária certa limitação da liberdade, por meio da interferência estatal. Os mais liberais, porém - como Locke, Mill, Constant e Tocqueville -, embora discordassem sobre qual deveria ser o grau de interferência estatal na vida do indivíduo, tinham certeza de que

\footnotetext{
142 "O sentido fundamental de liberdade é a liberdade dos grilhões, do aprisionamento, da escravidão por outros. O resto é extensão desse sentido, ou então é metáfora. Lutar para ser livre é procurar remover obstáculos; lutar pela liberdade pessoal é procurar pôr freio na interferência, exploração e escravização por parte de homens cujos fins são deles mesmos e não nossos". BERLIN, Isaiah. "Introdução". In: Quatro ensaios sobre a liberdade. Op. cit., p. 32.

${ }^{143}$ BERLIN, Isaiah. Estudos sobre a humanidade... Op. cit., p. 230. Ou, nas palavras de Feinberg: "O princípio anarquista, em resumo, só seria possível num mundo em que os desejos e as decisões humanas, por um milagre de harmonia preestabelecida, jamais pudessem entrar em conflito". Sobre esse pensamento, vejase FEINBERG, Joel. Filosofia social. Traduzido por Alzira Soares da Rocha e Helena Maria Camacho. Rio de Janeiro: Zahar Editores, 1974, p. 43.
} 
uma área mínima de não-interferência era necessária. E compreendiam que toda a forma de ampliação dessa área era uma ampliação da liberdade negativa.

\subsubsection{1 - Individualismo e liberdade}

Tal como Bobbio, Isaiah Berlin também observou a relação entre liberdade e individualismo. De modo particular, notou que a defesa da liberdade negativa especialmente a empreendida por Mill - guarda certa relação com uma concepção individualista do homem, uma concepção que exalta a espontaneidade e a diversidade como condições necessárias para o desenvolvimento do gênio humano e para o surgimento da verdade:

Toda a reivindicação de liberdades civis e direitos individuais, todo protesto contra a exploração e a humilhação, contra o abuso da autoridade pública, ou a hipnose de massa do costume ou da propaganda organizada, nasce dessa concepção individualista e muito controvertida acerca do homem $^{144}$.

Para Berlin, é possível defender a liberdade como boa, porque seu oposto, a interferência, muito embora às vezes seja necessária, "frustra desejos humanos": é a defesa clássica da liberdade em sua dimensão negativa. Porém, é possível igualmente defendê-la, diz Berlin, como o faz John Stuart Mill, com base naquela concepção individualista do ser humano. Nessa linha, a liberdade é boa por ser condição necessária para o florescimento da verdade ou para o desenvolvimento de determinadas aptidões humanas - como as que Mill considerava louváveis. A dificuldade em demonstrar essa controversa relação, torna, no entender de Berlin, bem mais vulnerável essa segunda forma de defender a liberdade ${ }^{145}$.

\footnotetext{
${ }^{144}$ BERLIN, Isaiah. Estudos sobre a humanidade.... Op. cit., p. 234.

${ }^{145}$ BERLIN, Isaiah. Estudos sobre a humanidade.... Op. cit., p. 235.
} 


\subsubsection{2 - Liberdade negativa e democracia}

As duas noções de liberdade encerram preocupações distintas e respondem a perguntas diferentes: não há ligação necessária entre a liberdade de matiz democrática e a noção liberal de liberdade. Essa é uma afirmação conhecida de Berlin, a qual desfaz, até certo ponto, a ideia de uma ligação conceitual entre liberalismo e democracia. Para Isaiah Berlin, tal conexão não há. Democracia e liberalismo são conceitos desvencilhados que personificam, por assim dizer, desejos diferentes. O desejo de se autogovernar e o de não sofrer interferências nas próprias ações podem ser igualmente profundos, mas são desejos diferentes. Tão diversos que ocasionaram "o grande confronto de ideologias que domina nosso mundo" $" 146$.

À primeira vista, os dois conceitos de liberdade não parecem tão distantes. De fato, "não ser impedido" e "ser seu próprio senhor" parecem, num certo sentido, modos idênticos de se viver a liberdade. Mas, se olharmos um pouco mais além, fautores da liberdade negativa (liberal) e da liberdade positiva (democrática) parecerão, como afirma Berlin, almejar coisas bem distintas:

Os primeiros querem refrear a autoridade como tal. Os últimos a querem colocada em suas próprias mãos. Essa é uma questão cardinal. Não são duas interpretações diferentes de um único conceito, mas duas atitudes profundamente divergentes e irreconciliáveis para com os fins da vida. Vale reconhecer essa divergência, mesmo que na prática seja frequentemente necessário chegar a uma solução de compromisso entre as duas ${ }^{147}$.

Berlin é um pensador bastante coerente. Essa descrição das duas liberdades oferece-lhe uma base sólida que lhe permite sutilmente defender a liberdade negativa como a verdadeira liberdade. Assim, inicialmente, ele descreve a democracia como incapaz, por si só, de proteger os mais preciosos valores liberais. Mas, no decorrer de sua exposição, é possível notar no pensamento de Berlin a quase inarticulada sugestão de que a democracia, não obstante defendida como o regime que melhor protege os princípios liberais, possui

\footnotetext{
${ }^{146}$ BERLIN, Isaiah. Estudos sobre a humanidade... Op. cit., p. 236.

${ }^{147}$ BERLIN, Isaiah. Estudos sobre a humanidade... Op. cit., p. 267.
} 
traços que denotam profunda hostilidade em relação a tais princípios. A base dessa sugestão é sua descrição da liberdade positiva ou democrática.

\subsection{2 - Dimensão positiva da liberdade}

Com vistas a compreender o tamanho de sua liberdade, pergunta-se a um transeunte o quanto o governo interfere em sua vida, ao que ele responde: "Eu me governo". Comumente, cremos que uma resposta desse jaez indica a liberdade total. Isso explica porque, como Norberto Bobbio bem observou, os fautores da liberdade democrática, a certa altura, consideraram irrelevante a preocupação com a liberdade como não-impedimento: se eu mesmo me governo, não faz sentido perguntar sobre o quanto o governo intervém em minha vida. Como vimos, Bobbio sagazmente explicou que, nas democracias possíveis, o autogoverno é institucionalmente imperfeito e que, por essa razão, subsistia ainda a necessidade de se preocupar com o grau de interferência do governo em nossas vidas privadas - pois, nas democracias possíveis, o "eu me governo" é mais hipotético que real ${ }^{148}$.

Diferentemente, para Isaiah Berlin, a ideia de autogoverno já é, em si, um problema. Além de insinuar a divisão de um sujeito em dois “eus", a noção de autogoverno (ou autodomínio) indica que é desejável o domínio de um "eu” sobre o outro. Em outras palavras, ela sugere que o "eu verdadeiro" deva subjugar o "falso".

\subsubsection{1 - Metáfora do autodomínio}

A expressão autogoverno é uma metáfora. No uso habitual do verbo "governar", seu sujeito e seu objeto não soem coincidir e o mesmo se dá com verbos sinônimos: o soberano governa seu súdito, o senhor domina seu escravo, o patrão comanda seus empregados. É evidente que a ideia de autogoverno foge a tal constância; nela, os elementos "dominante" e "dominado" são transportados para uma situação em que não há dois sujeitos, mas apenas um. E essa operação extravagante - consistente em tratar um

\footnotetext{
${ }^{148}$ BOBBIO, Norberto. Teoria geral da política... Op. cit., p. 282.
} 
sujeito como se fossem dois - apenas não nos causa espécie, porque está arraigada em nossas mais singelas e rotineiras reflexões.

O despertador toca. Uma parte de nós quer se levantar, pois bem se preocupa com os afazeres previstos para o dia; outra parte, porém, quer continuar dormindo, pois bem sabe desfrutar do prazer de um sono reparador ${ }^{149}$. O desejo de ser seu próprio senhor é o desejo de não se submeter a homem algum. Mas também é o desejo de não ser escravo das paixões, dos próprios instintos, da ignorância. O viciado que voluntariamente se interna numa casa de recuperação parece nutrir esse tipo de desejo. E também o homem de meia idade que se felicita com a obrigação de contribuir mensalmente para a previdência social; ou mesmo o indivíduo adulto que se lembra com gratidão das proibições que seus pais lhe impunham, pois as reconhece, hoje, como medidas acertadas.

Impulsos irracionais, desejos descontrolados, a busca por prazeres imediatos: tudo isso se identifica com o "eu" falso e deve ser eliminado ou, pelo menos, disciplinado. Já o ego verdadeiro é o racional, de natureza mais elevada, aquele que "calcula e visa ao que o satisfará a longo prazo"150, e que logo passa a ser identificado com o todo social do qual o indivíduo é apenas um membro. Como ensina Berlin, "o que confere a esse tipo de linguagem a sua plausibilidade é o fato de que reconhecemos ser possível, e às vezes justificável, coagir os homens em nome de alguma meta (...) que eles próprios buscariam atingir se fossem mais esclarecidos, mas que não o fazem porque são cegos, ignorantes ou corruptos"151. Assim, é fácil imaginar a coação sendo praticada para o bem e no interesse do coagido: toda postura paternalista carrega em si um pouco dessa concepção de "eu verdadeiro" e, talvez, a plausibilidade dessa concepção explique porque mesmo os pensadores mais liberais parecem aceitar algum tipo de paternalismo.

Todavia, com o tempo, essa visão plausível e inicialmente inofensiva pode tornar-se, com toda a probabilidade, uma forma de pensar carregada de autoritarismo e, em certo sentido, hostil à noção de liberdade como ausência de obstáculos à ação individual. Não por acaso, muitas das críticas ao paternalismo estatal e à própria liberdade positiva

\footnotetext{
149 Também Agostinho referiu-se ao sono para falar da guerra entre as duas vontades. SANTO AGOSTINHO. Confissões. Op. cit., p. 210.

${ }^{150}$ BERLIN, Isaiah. Estudos sobre a humanidade... Op. cit., p. 237.

${ }^{151}$ BERLIN, Isaiah. Estudos sobre a humanidade... Op. cit., p. 238.
} 
estão de certo modo ligadas a uma espécie de argumento da ladeira escorregadia ${ }^{152}$ : permitir que um terceiro - o governo, a sociedade - determine qual é seu "eu" verdadeiro pode significar, no futuro, o completo desprezo por suas mais sinceras inclinações e desejos. É precisamente um argumento desse tipo que Berlin utiliza quando diz:

Uma vez adotada essa visão, estou em posição de ignorar os desejos reais dos homens ou das sociedades, de amedrontá-los, oprimi-los, torturá-los em nome e no interesse de seus eus "reais", com base no conhecimento seguro de que tudo o que é a verdadeira meta do homem (a felicidade, o desempenho do dever, a sabedoria, uma sociedade justa, a autorealização) deve ser idêntico à sua liberdade - a escolha livre de seu eu "verdadeiro", ainda que frequentemente submerso e inarticulado ${ }^{153}$.

Como se vê, a noção de liberdade positiva está fortemente ligada a essa visão e, por isso, sua busca revela-se mais perigosa à liberdade negativa do que parecia no início. Tal perigo surge especialmente claro quando se estudam as duas principais manifestações da luta pela liberdade positiva, as quais Berlin chamou de "abnegação ascética" e "auto-realização". Na verdade, talvez a mais importante contribuição de Isaiah Berlin tenha sido justamente sua cuidadosa exposição de como o desejo de ser guiado por si mesmo manifestou-se nesses dois ideais.

\subsubsection{2 - A luta contra os desejos}

Às vezes, a busca pelo autogoverno é identificada com a luta para eliminar os desejos ou para resistir a eles. Se ser senhor de si mesmo equivale a não ser escravo de desejos incontroláveis, basta eliminar esses desejos para alcançar a liberdade: das coisas que um homem deseja profundamente, muitas não está seguro de poder alcançar; libertase, pois, abstendo-se de desejá-las; e, desse modo, amplia sua liberdade "positiva". Esse ideal, que os estoicos já professavam, faz parecer que abandonar o caminho seja a melhor maneira de eliminar os obstáculos ao longo dele; faz parecer que o caminho para liberdade

\footnotetext{
${ }^{152}$ Sobre o argumento da "ladeira escorregadia", ver: SUDATTI, Ariani Bueno. Raciocínio jurídico e nova retórica. São Paulo: Ed. Quartier Latin do Brasil, 2003, pp. 110-111.

${ }^{153}$ BERLIN, Isaiah. Estudos sobre a humanidade... Op. cit., p. 238.
} 
consista em não desejar aquilo que não se pode alcançar ${ }^{154}$. O equívoco desse ideal é logo revelado: livrar-se dos desejos não é um meio de se aumentar a liberdade. Como afirma Berlin:

\begin{abstract}
A abnegação ascética pode ser uma fonte de integridade, serenidade e força espiritual, mas é difícil entender como pode ser considerada um aumento da liberdade. Se escapo de um adversário retirando-me para dentro de casa e trancando qualquer entrada e saída, posso continuar mais livre do que se tivesse sido capturado pelo inimigo, mas sou mais livre do que se o tivesse derrotado ou capturado? (...) A culminação lógica do processo de destruir tudo o que pode me ferir é o suicídio ${ }^{155}$.
\end{abstract}

Em última análise, esse ideal de renúncia a desejos busca preservar o indivíduo das frustrações sentidas por não se concretizarem desejos e sonhos. É menos um sonho de liberdade que uma busca por segurança ${ }^{156}$. Mais uma vez, aparece a profunda incompatibilidade entre os dois conceitos de liberdade. Porque, enquanto a luta pela liberdade positiva exige que o indivíduo renuncie aos rumos que deseja seguir, a luta pela liberdade negativa, ao contrário, desafia-lhe a trilhar tais rumos, de modo que a assunção de uma implica a renúncia à outra.

\title{
2.2.2.3 - A busca por conhecimento
}

Ao longo da história, a busca por autogoverno também esteve associada à busca pelo conhecimento racional. Esse aspecto da liberdade positiva é particularmente importante nos escritos de Isaiah Berlin - e deveras relevante no presente estudo - porque põe em evidência as problemáticas relações entre verdade racional e liberdade humana. A metáfora do autodomínio, ao sugerir a existência de um "eu verdadeiro" que deve prevalecer, aponta imediatamente para o círculo de questões que envolvem o problema filosófico da verdade. Com efeito, os desejos incontroláveis do indivíduo podem muito bem ser considerados frutos de sua ignorância ou incompreensão. Nessa visão racionalista, a busca pela liberdade passa necessariamente pela compreensão do mundo que nos cerca.

\footnotetext{
${ }^{154}$ Sobre esse ideal estoico, veja-se GILSON, Étienne. O espírito da filosofia medieval. Op. cit., p. 383.

${ }^{155}$ BERLIN, Isaiah. Estudos sobre a humanidade... Op. cit., p. 244.

${ }^{156}$ BERLIN, Isaiah. Estudos sobre a humanidade... Op. cit., p. 241.
} 
Desde o início, a filosofia tem se preocupado com a existência da verdade e o acesso a ela. Muitos filósofos não demoraram a concluir que o universo é regido por leis necessárias e imutáveis e que compreendê-las é o único meio de se libertar. Desejar "que

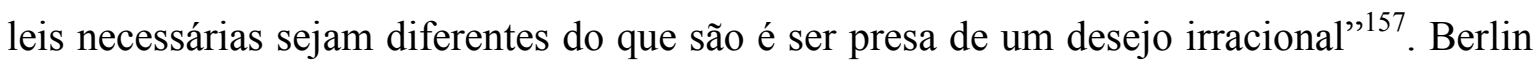
nos mostra, com mestria, que o credo racionalista alimentou a ideia de que o autogoverno concretiza-se apenas por meio da compreensão racional do mundo. Segundo tal pensamento, compreender o mundo é ser libertado, pois aquilo cuja necessidade compreendemos não podemos desejar que seja de outra forma. O conhecimento liberta: esse é o "âmago metafísico do racionalismo"158.

Mas, tal como a abnegação ascética, esse ideal racionalista pode ser visto, também, menos como ideal de liberdade, e mais como a mera busca por uma vida sem frustrações. Porque, se o conhecimento nos torna livres, ele não o faz "oferecendo-nos mais possibilidades abertas de escolha, mas preservando-nos da frustração de tentar o impossível"159. Ainda assim, afirma Berlin, é por essa liberdade que lutam as democracias e ditaduras; e é essa "doutrina positiva da libertação pela razão" que está no cerne de "muitos credos nacionalistas, comunistas, autoritários e totalitários" $" 160$. Segundo ele,

Aqueles que acreditavam na liberdade como autogoverno racional estavam fadados, mais cedo ou mais tarde, a considerar que isso não se devia aplicar apenas à vida interior de um homem, mas a suas relações com os outros membros de sua sociedade. Até os mais individualistas dentre eles - e Rousseau, Kant e Fichte certamente começaram como individualistas - passaram, em algum ponto, a se perguntar se não era possível uma vida racional, não só para o indivíduo, mas também para a sociedade, e, nesse caso, como isso deveria ser alcançado ${ }^{161}$.

Com bastante sutileza, Berlin expõe a força do argumento racionalista em favor da liberdade como autogoverno. Segundo ele, mesmo os pensadores indiscutivelmente liberais e comprometidos com o individualismo foram, em algum

\footnotetext{
${ }^{157}$ BERLIN, Isaiah. Estudos sobre a humanidade... Op. cit., p. 248.

${ }^{158}$ Ibidem.

${ }^{159}$ Ibidem.

${ }^{160}$ Ibidem.

${ }^{161}$ BERLIN, Isaiah. Estudos sobre a humanidade... Op. cit., pp. 248-249. Em relação a Kant, vimos em 1.5.3 que sua postura ambígua diante dos governos absolutistas decorre de sua ambiguidade ante o absolutismo filosófico. Ver KELSEN, Hans. A democracia. Op. cit., p. 354. Além disso, depois do brilhante ensaio de Bobbio sobre as duas liberdades em Kant, ficou evidente a confusão de Kant ante os dois famosos conceitos de liberdade. Veja-se BOBBIO, Norberto "Kant e as duas liberdades". In: Teoria geral da política. Op. cit., 101-113.
} 
momento, levados a defender posturas inequivocamente autoritárias ${ }^{162}$. Locke e Montesquieu, por exemplo, a despeito de serem genuínos autores liberais - para os quais a liberdade é, em sua essência, ausência de impedimentos - houveram por bem ponderar que, na sociedade civil, liberdade é "viver segundo uma regra permanente"163; ou que liberdade é o "poder de fazer aquilo que devemos querer" "164. E até nosso estimado John Stuart Mill considerou que é justo usarmos a força para impedir um homem de atravessar uma ponte insegura, sem que isso represente "alguma real violação a sua liberdade", pois "a liberdade consiste em fazer o que se deseja, e ninguém deseja cair no rio"165. Ou seja, segundo o argumento racionalista: 1) é possível dizer, com segurança, o que é bom para o outro; e 2) se alguém é forçado em nome de seu próprio bem, então não está sendo coagido. E, se até os pensadores liberais renderam-se, em alguns momentos, a tais conclusões, isso se deve à enorme plausibilidade que o argumento racionalista apresenta.

A estrutura do argumento é bem simples. Por meio da razão, a verdade pode ser descoberta e demonstrada com toda a clareza. Um pensador racional poderia explicar todas as verdades "tão claramente que todos os outros homens racionais não poderiam deixar de aceitá-las" ${ }^{\prime 166}$. Um Estado racional é aquele cujas leis nenhum homem racional rejeitaria, pois uma ordem verdadeiramente justa possibilita soluções corretas para todos os problemas - e homens racionais não iriam querer outra coisa senão obedecer a essa ordem justa: num universo governado pela razão não há necessidade de coerção ${ }^{167}$.

Está traçado o caminho rumo ao despotismo. Pois, à luz desse raciocínio, não é tirania obrigar meu "eu" falso a se adaptar aos padrões corretos. Daí a atenção que os racionalistas dão à educação e à questão de como tornar racionais os homens. E, no mesmo passo, a ideia de que não há direitos contra a razão, pois a liberdade "não é a liberdade de fazer o que é irracional, estúpido ou errado" ${ }^{168}$. Há sempre pessoas certas de que conhecem

\footnotetext{
${ }^{162}$ BERLIN, Isaiah. Estudos sobre a humanidade... Op. cit., pp. 251-253. Trata-se de um movimento ao longo daquilo que Celso Lafer chamou de "caminho de mão única do despotismo da evidência"162. LAFER, Celso. "O moderno e o antigo conceito de liberdade". Op. cit., p. 29.

${ }^{163}$ LOCKE, John. Dois Tratados sobre o Governo. Traduzido por Julio Fischer; rev. técnica de Renato Janine Ribeiro. São Paulo: Martins Fontes, 2005, p. 403.

${ }^{164}$ MONTESQUIEU, Baron Charles de Secondat. O espirito das leis. In: MORRIS, Clarence. Os grandes filósofos do direito: leituras escolhidas. Traduzido por Reinaldo Guarany. São Paulo: Ed. Martins Fontes, 2002, p. 166.

${ }^{165}$ MILL, John Stuart. A liberdade / Utilitarismo. Traduzido por Eunice Ostrensky. São Paulo: Martins Fontes, 2000, p. 147.

${ }^{166}$ BERLIN, Isaiah. Estudos sobre a humanidade... Op. cit., p. 249.

${ }^{167}$ BERLIN, Isaiah. Estudos sobre a humanidade... Op. cit., p. 251.

${ }^{168}$ BERLIN, Isaiah. Estudos sobre a humanidade... Op. cit., p. 251.
} 
a verdade e ansiosamente dispostas a coagir os demais em nome dela. Nessa ladeira escorregadia, é muito difícil evitar que o racionalismo culmine em tirania.

Além disso, o racionalismo guarda íntima relação com uma noção determinista explicitamente contrária à tradicional concepção de livre-arbítrio. Essa relação, que torna o racionalismo ainda mais inadequado aos princípios liberais, é exposta por Berlin em seu ensaio "A inevitabilidade histórica".

Nesse ensaio, Isaiah Berlin trata de "duas poderosas doutrinas" difundidas no pensamento contemporâneo: o determinismo e o relativismo ${ }^{169}$. Determinismo é como frequentemente se designa a noção de que a história humana é causalmente determinada por leis universais necessárias. É possível encontrar suas raízes tanto no racionalismo metafísico, quanto no fascínio pelas descobertas das ciências naturais - pois, embora o método científico seja "a própria negação da especulação metafísica", ambos têm em comum a inclinação para explicar os fatos como aplicações concretas de fórmulas ou leis gerais ${ }^{170}$. Berlin explica que o determinismo tem como mais notório efeito a afirmação de que a liberdade de escolha do indivíduo não passa de uma mera ilusão ${ }^{171}$.

Já o relativismo apresenta-se como a doutrina oposta: de um lado, postula que nada é absoluto e que as regras morais variam no tempo e no espaço; de outro, sustenta a falibilidade humana e assevera que os homens estão fadados a conhecer apenas uma ínfima parte das leis que regem o universo. Sua proximidade com o relativismo filosófico descrito por Kelsen é óbvia e seu significado, ao contrário do determinismo, não é de modo algum incompatível com a crença na liberdade humana de escolha ${ }^{172}$.

No entanto, segundo Berlin, determinismo e relativismo são doutrinas equivocadas, pois inviabilizam qualquer forma de responsabilização dos indivíduos ou julgamento de suas condutas. O determinismo erra, porque apresenta o indivíduo como um ser não-livre e que, por isso, não pode ser julgado por seus atos; o relativismo, porque nega qualquer padrão moral em referência ao qual se possa proceder a julgamentos ou críticas.

\footnotetext{
${ }^{169}$ BERLIN, Isaiah. “A inevitabilidade histórica”. In: Estudos sobre a humanidade... Op. cit., p. 215.

${ }^{170}$ BERLIN, Isaiah. Estudos sobre a humanidade... Op. cit., p. 172.

${ }^{171}$ BERLIN, Isaiah. Estudos sobre a humanidade... Op. cit., pp. 168-173.

172 BERLIN, Isaiah. Estudos sobre a humanidade... Op. cit., pp. 193-197. Sobre o relativismo filosófico defendido por Hans Kelsen, ver item 1.5.3.
} 
Para essas duas doutrinas, portanto, é inadequado falar em heróis ou vilões morais da história. Julgar, criticar, elogiar, repreender, responsabilizar são práticas sem sentido quando o indivíduo é mero joguete das leis e forças inevitáveis - ou quando, embora livre o indivíduo, não há padrão objetivo para se realizar qualquer uma dessas avaliações. Por isso são doutrinas equivocadas. O homem pode pensar, diz Berlin, que não goza de liberdade alguma, mas não consegue agir conforme tal crença. Pode pensar que a história deva ser escrita sem referência a julgamentos morais, mas não consegue, ele próprio, descrevê-la sem fazer uso dos conceitos morais arraigados em sua linguagem ${ }^{173}$.

É verdade, porém, que Berlin criticou mais severamente o determinismo que o relativismo - como, aliás, se pode ver a partir do ensaio "Dois conceitos de liberdade", no qual foram dedicadas várias páginas para se falar dos perigos da postura racionalista. Em primeiro lugar, porque o relativismo mostra-se inicialmente como uma postura mais humilde; como um contraponto ao dogmatismo e à confiança exagerada do racionalismo e, nesse aspecto, é para Berlin uma postura mais humana e convincente ${ }^{174}$. Depois, o relativismo - quando não levado ao extremo de aniquilar nossa capacidade de compreender os padrões alheios - tem a virtude de soar como uma verdadeira afirmação da liberdade humana, especialmente quando nos faz recordar que são muitos (e, às vezes, irreconciliáveis) os propósitos perseguidos pelos homens ${ }^{175}$. Aliás, é esse relativismo "brando" - matizado pela possibilidade de diálogo entre as culturas - que Berlin chamou de pluralismo e que tão vigorosamente defendeu em alguns de seus escritos ${ }^{176}$. Quanto ao determinismo racionalista, Berlin criticou-o por sua explícita hostilidade à ideia de liberdade. De todo modo, como se observa a partir dos ensaios de Berlin, o racionalismo influenciou inúmeras doutrinas políticas.

Por tudo isso, Berlin considera a liberdade como autogoverno uma perigosa ameaça para a liberdade negativa. Porque a linguagem racionalista que lhe subjaz - a qual em nada se afasta do absolutismo filosófico apontado por Kelsen ${ }^{177}$ - é extremamente persuasiva, em que pese sua notória incompatibilidade com a defesa da liberdade humana.

\footnotetext{
${ }^{173}$ BERLIN, Isaiah. Estudos sobre a humanidade... Op. cit., pp. 179-182 e pp. 215-225.

${ }^{174}$ BERLIN, Isaiah. Estudos sobre a humanidade... Op. cit., pp. 193-202.

${ }^{175}$ BERLIN, Isaiah. Estudos sobre a humanidade... Op. cit., pp. 211-213.

${ }^{176}$ Especialmente no ensaio "A busca do ideal". BERLIN, Isaiah. "A busca do ideal". In: Estudos sobre a humanidade... Op. cit., pp. 41-57.

${ }^{177}$ Veja-se o item 1.5.3.
} 


\subsubsection{4 - A busca por reconhecimento}

Mas há, ainda, outro motivo pelo qual o desejo por liberdade muitas vezes conduz a desfechos tirânicos: a confusão que há entre a busca por liberdade e a busca por reconhecimento ou status $^{178}$. Fraternidade e igualdade são irmãs da liberdade, mas com ela não se confundem. Muitas vezes, o indivíduo diz estar lutando por sua liberdade, mas o que ele quer, no fundo, é apenas ser reconhecido pela comunidade a que pertence: quer ser reconhecido como igual, quer ver sua vontade levada em consideração, quer ser compreendido; ou, simplesmente, quer evitar ser ignorado, desprezado ou tratado com superioridade. Trata-se de um sentimento que exalta os valores da igualdade e da fraternidade. Por trás disso está a ideia de que o ego somente encontra sua identidade na comunidade da qual provém - a ideia de que ser reconhecido como membro de um grupo ou uma classe está, de algum modo, ligado a importantes atributos de minha própria identidade.

Conforme já observamos, para Isaiah Berlin, a democracia não necessariamente propicia liberdade negativa. Ele considera que governos absolutistas podem ser mais liberais que algumas democracias, desde que eles imponham, comparativamente, menos impedimentos à ação individual. No entanto, diz Berlin, apenas essa busca por reconhecimento explica por que as democracias mais autoritárias são conscientemente preferidas a "oligarquias mais esclarecidas" "179. Apenas a confusão entre o desejo de liberdade e o anseio profundo por "status" pode explicar por que homens submetidos ao mais duro despotismo afirmam, "com toda a aparência de sinceridade", que isso os liberta ${ }^{180}$.

Mas Berlin não deixa de reconhecer que a busca por reconhecimento está muito próxima do desejo de ser livre. No fundo, não se trata de uma mera confusão. Quem empreende a busca por reconhecimento, de certo modo, tem como desiderato um pouco do sentido "positivo" de liberdade, pois quer ser governado por algo que, de algum modo, reconhece como sendo "seu"

\footnotetext{
${ }^{178}$ BERLIN, Isaiah. Estudos sobre a humanidade... Op. cit., p. 257.

${ }^{179}$ BERLIN, Isaiah. Estudos sobre a humanidade... Op. cit., p. 260.

${ }^{180}$ Ibidem.

${ }^{181}$ BERLIN, Isaiah. Estudos sobre a humanidade... Op. cit., p. 262.
} 
reconhecimento dá sentido mais amplo à crítica kantiana em relação ao paternalismo. $\mathrm{O}$ paternalismo não é ruim apenas porque subtrai a autodeterminação do sujeito, mas também porque o trata como inferior (não-igual), ou como menos capaz do que realmente é ${ }^{182}$.

Para além disso, a busca por reconhecimento corrobora a premissa pluralista de Berlin. Nem todos os grandes valores da humanidade são compatíveis. Assim, malgrado saibamos que as diversas acepções de "liberdade" contêm um mínimo daquilo que Berlin chamou de sentido "negativo", o fato é que muitas pessoas estão dispostas a sacrificar sua liberdade "negativa" a valores outros, tais como a igualdade ou a fraternidade.

\subsection{3 - O velho problema da vontade livre}

Conforme observamos em 2.1.1.2, a partir da distinção pauliana entre querer e poder, a filosofia medieval passou a trabalhar com a certeza de que a vontade individual é necessariamente livre. Havia, porém, duas dificuldades já mencionadas: compreender como uma vontade poderia ser livre e, ao mesmo tempo, estar sujeita às leis necessárias do universo; e entender como ela poderia ser livre e, ao mesmo tempo, atuar como uma vontade dividida contra si mesma.

O exame realizado neste capítulo sobre os dois sentidos de liberdade liberdade liberal (negativa) e liberdade democrática (positiva) - permitiu-nos perceber uma diferença de posturas em face de tais dificuldades. A preocupação com a liberdade negativa não parece, em momento algum, pôr em dúvida a liberdade inerente à vontade pois, como vimos, os liberais modernos compreendiam a liberdade como ausência de impedimentos para se fazer o que se tem vontade de fazer. Se eles nutriam qualquer dúvida sobre como a vontade poderia ser livre, então não a colocavam em primeiro plano: porque, na defesa que faziam da liberdade, o que importava era afastar da esfera individual os obstáculos postos pelo governo. A liberdade positiva, ao contrário, insinua a existência de dois egos em um mesmo indivíduo e, por essa razão, acaba por retomar, ainda que implicitamente, a ideia de uma vontade em luta consigo mesma. Mais do que isso, com sua preocupação pelo autogoverno, a liberdade positiva coloca em primeiro plano o problema

${ }^{182}$ BERLIN, Isaiah. Estudos sobre a humanidade... Op. cit., p. 259. 
da guerra entre as vontades num mesmo sujeito. Sua busca, então, torna-se a busca pela vontade "verdadeira", "justa", "racional".

Liberdade e vontade, além de conceitos intimamente ligados, são temas repletos de armadilhas.

Poucos pensadores cuidaram tão bem do tema da vontade quanto a filósofa alemã Hannah Arendt. Numa obra heroica em que se propõe a estudar as faculdades do espírito (pensamento, vontade e juízo), Hannah Arendt propõe-se, igualmente, a historiar o conceito de vontade no curso de nossa tradição filosófica. O resultado de sua empresa é admirável.

$\mathrm{Na}$ análise histórica de tal faculdade espiritual, Arendt ensina que a vontade - diferentemente do pensamento, mas tal como o juízo - consiste em uma faculdade mais próxima do mundo das aparências e que, ao invés de lidar com as generalizações, está sempre ligada ao concreto, ao particular. A volição, diz Hannah Arendt, é a capacidade que os homens têm de decidir "quem" eles serão e "como" apresentarão a si mesmos no mundo das aparências ${ }^{183}$. Por isso, enquanto o juízo lida com coisas que já foram, a vontade é o órgão espiritual voltado para o futuro; para aquilo que ainda não é e que poderá nunca vir a $\operatorname{ser}^{184}$.

Essa filósofa também mostra que, no decorrer da história, muitos pensadores investiram contra a ideia de vontade, tachando-a como mera ilusão - autores entre os quais estão os racionalistas Hegel e Espinosa. Essa desconfiança dos filósofos em relação à noção de vontade é permanentemente despertada pela íntima conexão que ela mantém com a ideia de liberdade ${ }^{185}$. "A Vontade, ao que parece, é caracterizada por uma liberdade infinitamente maior que o pensamento" ${ }^{\# 6}$. Daí o grande conflito entre o pensar e o querer, duas atividades que parecem "incapazes de coexistir" 187.

${ }^{183}$ ARENDT, Hannah. A vida do espírito: o pensar, o querer, o julgar. Traduzido por Antonio Abranches e Helena Franco Martins. 2. ed. Rio de Janeiro: Civilização Brasileira, 2010, p. 236-237.

${ }^{184}$ ARENDT, Hannah. A vida do espírito... Op. cit., pp. 273-274.

${ }^{185}$ ARENDT, Hannah. A vida do espírito... Op. cit., pp. 284-287.

${ }^{186}$ ARENDT, Hannah. A vida do espírito... Op. cit., p. 287

${ }^{187}$ ARENDT, Hannah. A vida do espírito... Op. cit., p. 296. 
De fato, a necessidade sói agradar mais aos filósofos do que esse mito incompreensível a que chamamos liberdade ${ }^{188}$. Como vimos, ao examinar o ensaio de Berlin, o racionalismo filosófico parece incompatível com a liberdade. No fundo, o conhecimento de leis racionais necessárias que regem todo o universo é tão incompatível com a ideia de liberdade humana, quanto é a crença num Criador onipotente e onisciente. Trata-se, como se vê, do velho conflito entre livre-arbítrio e determinismo.

Mas o próprio Isaiah Berlin parece nos indicar que a dificuldade causada por esse conflito é apenas aparente. Porque, tão logo somos acometidos pelo desconforto de sentir o pensamento esmagar a liberdade - e sempre que o pensador se põe a refletir sobre a causalidade, a liberdade parece não mais existir - uma ponderação suficientemente persuasiva de Berlin nos coloca em outro rumo: segundo ele, embora seja perfeitamente possível pensar que não somos livres, é impossível agir como se não fôssemos livres ${ }^{189}$. Em outras palavras: na prática, a dúvida quanto à existência da liberdade (ou da vontade livre) não parece fazer diferença ${ }^{190}$.

Também Hannah Arendt aponta para essa conclusão, quando diz que não os pensadores profissionais, mas somente os homens de ação estão comprometidos com a liberdade ${ }^{191}$. Depois de aludir à distinção entre "liberdade filosófica" e "liberdade política" - enunciada inicialmente por Montesquieu ${ }^{192}$ - ela afirma que a liberdade filosófica é um atributo do querer. A liberdade política, diferentemente, é uma qualidade do $\operatorname{poder}^{193}$ : a

\footnotetext{
${ }^{188}$ ARENDT, Hannah. A vida do espírito... Op. cit., pp. 463-467.

${ }^{189}$ BERLIN, Isaiah, “A inevitabilidade histórica”. In: Estudos sobre a humanidade... Op. cit., p. 184.

${ }^{190}$ A respeito da inevitabilidade histórica Berlin afirma: "Claro, essa conclusão severa não é realmente aceita por nenhum historiador ativo e nenhum ser humano em seus momentos não teóricos". BERLIN, Isaiah, "A inevitabilidade histórica". In: Estudos sobre a humanidade... Op. cit., p. 182.

191 ARENDT, Hannah. A vida do espírito... Op. cit., p. 467. Não há espaço aqui para examinarmos as interessantes conclusões da reflexão arendtiana acerca da liberdade. Para uma visão geral do pensamento de Arendt a respeito da liberdade, remetemos o leitor a seu ensaio sobre o tema. ARENDT, Hannah. "Que é a liberdade?”. In: Entre o passado e o futuro. Traduzido por Mauro W. Barbosa de Almeida. 2. ed. São Paulo: Editora Perspectiva, 1972, pp. 188-220.

${ }^{192}$ ARENDT, Hannah. A vida do espírito... Op. cit., pp. 467. Montesquieu afirma: "A liberdade filosófica consiste no livre exercício da vontade; ou pelo menos, se devemos falar de acordo com todos os sistemas, na opinião de que gozamos do livre exercício da vontade. A liberdade política consiste na segurança, ou pelo menos na opinião de que desfrutamos de segurança". MONTESQUIEU, Baron Charles de Secondat. $O$ espírito das leis. Op. cit., p. 168.

${ }^{193}$ ARENDT, Hannah. A vida do espírito... Op. cit., p. 469. Em ensaio anterior, o qual versava sobre o conceito de liberdade, Hannah Arendt já havia indicado essa conclusão. Nesse texto, ela demonstra como Kant já havia salvado a noção de liberdade quando engendrou a famosa distinção entre "razão pura" e "razão prática". Na teoria de Kant, diz Arendt, o centro da razão prática é a vontade livre; o "agente dotado de livre arbítrio, que é na prática importantíssimo, jamais aparece no mundo fenomênico”. Embora assaz engenhosa, diz a autora, a solução kantiana não soluciona o maior problema que é o pensamento eliminar a liberdade.
} 
liberdade filosófica (instalada no interior da vontade) "é relevante somente para pessoas que vivem fora das comunidades políticas" ${ }^{2194}$.

Assim, em sua vida cotidiana, o conflito entre liberdade e necessidade passa despercebido ao indivíduo enquanto ele pratica suas ações. No entanto, sabemos que tal conflito continua a ser um problema sempre que o estudioso teoriza sobre governos, sociedades e cidadãos. A essa dificuldade persistente dedicaremos o capítulo 3.

\subsection{4 - Pluralismo e liberdade}

Para Isaiah Berlin, a crença de que existe uma solução final, uma resposta definitiva para todos os grandes problemas da humanidade foi a responsável pela matança de pessoas "nos altares dos grandes ideais históricos" $" 195$. Cuida-se de uma crença, a princípio, bastante atrativa: muitos pensadores foram guiados por essa crença e grandes tradições religiosas a intuíram. De acordo com essa crença, há uma resposta certa para cada uma das grandes questões da humanidade e, além de existir uma forma segura para se chegar a tais respostas, elas são necessariamente compatíveis entre si: formam um conjunto harmônico ${ }^{196}$. Ao longo de sua obra, Berlin assumiu e articulou o credo oposto: um pluralismo objetivo que, centrado nos ideais liberais, exaltava a importância da diversidade e a riqueza do diálogo entre culturas, e que apontava a realidade de um mundo com valores não necessariamente harmônicos: um mundo (o nosso mundo) em que a "verdade não é uma, mas múltipla"197.

O ideal do pluralismo é defendido por Berlin em mais de uma obra - e é especialmente descrito em seu ensaio "A busca do ideal"198. Embora correndo o risco de não se fazer justiça à robustez de uma ideia tão cara a seu pensamento, ousamos aqui descrever sinteticamente o pluralismo de Berlin: a visão pluralista reconhece que os grandes valores positivos da humanidade não são necessariamente compatíveis entre si,

ARENDT, Hannah. Entre o passado e o futuro. Traduzido por Mauro W. Barbosa de Almeida. 2. ed. São Paulo: Editora Perspectiva, 1972, p.190.

${ }^{194}$ ARENDT, Hannah. A vida do espírito... Op. cit., p. 467.

${ }^{195}$ BERLIN, Isaiah. Estudos sobre a humanidade... Op. cit., p. 268.

${ }^{196}$ BERLIN, Isaiah. Estudos sobre a humanidade... Op. cit., p. 41-46.

${ }^{197}$ LAFER, Celso. Hannah Arendt: pensamento, persuasão e poder. 2. ed. São Paulo: Paz e Terra, 1988, pp. 142-143.

${ }^{198}$ BERLIN, Isaiah. “A busca do ideal”. In: Estudos sobre a humanidade... Op. cit., pp. 41-57. 
embora continuem sendo valores profundamente importantes; reconhece que os homens podem perseguir muitos objetivos diferentes, o que não os impede de compreender uns aos outros.

Aqueles que têm uma visão pluralista, tal como a defendida por Berlin, reconhecem com serenidade a falibilidade da razão humana e, por isso, consideram seriamente a possibilidade de que nunca venhamos a alcançar as certezas a respeito da vida e da natureza que nos envolve. Aliás, consideram seriamente a possibilidade de sequer existirem respostas certas - ou de não serem elas harmônicas entre si. Enfim, compreendem perfeitamente a possibilidade de não haver uma solução final e conciliatória $^{199}$.

Berlin leva a sério essas ideias. Antes de ser uma postura, o pluralismo é um dado da realidade ${ }^{200}$. Para ele, é evidente que nem todos os grandes bens podem coexistir: a colisão de valores é inevitável e estamos fadados a optar por alguns dentre eles. Sim, diz ele, muitos problemas da sociedade podem ser resolvidos, mas a história mostra que "toda solução cria uma nova situação que gera as suas novas necessidades e problemas, novas demandas" 201 . Cada nova geração esquece os antigos males e tem de enfrentar novos: a possibilidade de uma solução final para todos os problemas revela-se uma completa ilusão. E até certo ponto perigosa, pois "se alguém realmente acredita que tal solução seja possível, então certamente nenhum custo será demasiado elevado para obtê-la": daí as tragédias ocasionadas por essa crença inabalável ${ }^{202}$.

Mas, se não há uma teoria - ou uma religião, ou um sistema de pensamento - que possam nos mostrar as respostas certas para todas as nossas questões, ou mesmo se nem existem respostas certas, como saber que caminho devemos seguir? Como escolher entre as diversas possibilidades que o mundo nos apresenta? Se os trade-offs são inexoráveis, não há outra solução senão minimizá-los: tentar soluções de compromisso, sopesar reivindicações, estabelecer prioridades - estas nunca definitivas ou absolutas - são

\footnotetext{
${ }^{199}$ Nem é preciso ressaltar a semelhança entre a postura pluralista e o relativismo filosófico que abordamos em 1.5.3, descrito por Kelsen como uma postura filosófica que se associa, no campo da política, aos governos não absolutistas e, em especial, à democracia.

${ }^{200}$ Como bem observou José Guilherme Merquior: "É inevitável o pluralismo de valores, Berlin insiste - e, em consequência, também o são o conflito e a escolha". MERQUIOR, José Guilherme. O liberalismo antigo e moderno. Op. Cit., p. 187.

${ }^{201}$ BERLIN, Isaiah. Estudos sobre a humanidade... Op. cit., p. 52.

${ }^{202}$ BERLIN, Isaiah. Estudos sobre a humanidade... Op. cit., p. 53.
} 
remédios que permitem, segundo Berlin, o convívio de pessoas numa "sociedade decente"203. Uma sociedade que cumpre sua obrigação pública número um: a de evitar "os limites máximos do sofrimento"204.

Nada há que se possa fazer além disso. Na verdade, se fosse possível encontrar uma solução final, a necessidade e a angústia da escolha desapareceriam. É precisamente essa impossibilidade de se obter uma resposta final e conciliatória que torna a liberdade um bem extremamente valoroso. Para Berlin, a necessidade de escolher é o que nos caracteriza como seres humanos. Daí ser o pluralismo um ideal mais humano: ele reconhece as pessoas como agentes livres; ele não supõe que "todos os valores possam ser graduados numa única escala"205.

\section{3 - Síntese de Bobbio e Berlin}

O conflito entre a regra da maioria e a liberdade individual está fortemente relacionado com a distinção entre liberdade positiva e liberdade negativa. Ronald Dworkin, um respeitado filósofo do direito de nosso tempo, afirmou expressamente tal conexão, e utilizou-se daquela distinção para explicar por que, segundo ele, uma sociedade democrática deve manter instituições preocupadas com a busca por respostas certas quanto a seus princípios e com a proteção de direitos fundamentais em face do princípio majoritário $^{206}$.

Neste capítulo, tivemos a oportunidade de examinar os principais argumentos lançados sobre o tema, que ora apontavam a incompatibilidade entre as duas liberdades, ora sua complementaridade. Para encerrá-lo, vale recapitular sinteticamente algumas das ideias expostas.

Para Isaiah Berlin, a genuína liberdade é aquela a que chamou liberdade negativa e que encerra uma preocupação diametralmente oposta à que o sentido positivo de

\footnotetext{
${ }^{203}$ BERLIN, Isaiah. Estudos sobre a humanidade... Op. cit., p. 56

${ }^{204}$ BERLIN, Isaiah. Estudos sobre a humanidade... Op. cit., p. 55. Na mesma página: “As soluções utilitárias são às vezes erradas, mas, suspeito, na maioria das vezes benignas".

${ }^{205}$ BERLIN, Isaiah. Estudos sobre a humanidade... Op. cit., p. 272.

${ }^{206}$ DWORKIN, Ronald. "The Moral Reading and the Majoritarian Premise". In: KOH, Harold H. e SLYE, Ronald C. (organizadores). Deliberative democracy and human rights. New Haven e Londres: Yale University Press, 1999, pp. 81-115.
} 
liberdade implica. Segundo esse autor, a liberdade positiva, por encerrar uma nítida preocupação com o autodomínio, sugere a existência de dois “eus" ou, como aqui salientado, remonta à histórica e problemática noção de uma vontade dividida, em luta contra si mesma. Tanto a postura paternalista, que crê estar coagindo em benefício de quem sofre a coação, quanto o autoritarismo baseado na crença em respostas únicas, ambos se beneficiam dessa sugestão de que há uma vontade dividida. Bem por isso - e pela íntima relação que há entre racionalismo e determinismo - a liberdade positiva, calcada na metáfora do autodomínio, não apenas está desvencilhada da liberdade negativa, como lhe é perniciosa.

Por outro lado, em seus escritos, Berlin enfatiza o valor da liberdade negativa quando iluminada pelo pluralismo que ele defende: num mundo onde não se pode ter certeza de serem alcançáveis as respostas para nossas questões mais profundas, onde não se pode ter certeza sobre quais os valores mais importantes, sobre quais as formas de governo mais adequadas - enfim, onde a própria existência de certezas acerca dessas questões não pode ser razoável e peremptoriamente afirmada -, a liberdade individual como não-interferência, essa aptidão genuinamente humana de escolher entre um caminho e outro, ganha enorme importância. Porém, ao mesmo tempo, a postura pluralista é mais humana justamente porque coloca a liberdade em primeiro plano.

Em suma, no ensaio "Dois conceitos de liberdade", Berlin deixa claro que o mero ideal democrático do autogoverno não protege, per se, as liberdades individuais (a liberdade negativa). É sempre possível encontrar na democracia as dificuldades trazidas pela preocupação com a liberdade positiva: o paternalismo abusivo e o autoritarismo surgem quando a maioria governante crê-se possuidora da verdade. Em outras palavras, o que se extrai de seu ensaio é a denúncia, pese embora dispersa e implícita, de que a democracia não consegue, sozinha, defender o ideal liberal do pluralismo - e que às vezes representa um perigo a ele.

Quanto a Norberto Bobbio, vimos que sua exposição sobre as duas concepções de liberdade serviu como pano de fundo para que ele demonstrasse a compatibilidade entre democracia e liberalismo. Ao mesmo tempo em que procurou provar a complementaridade entre os dois sentidos de liberdade, insistiu em apresentar a democracia como um aperfeiçoamento do liberalismo, asseverando, porém, que a liberdade democrática não substitui a liberdade como não-impedimento. Em seu ensaio "Da 
liberdade dos modernos comparada à dos pósteros", Bobbio ainda salienta que é duvidoso falar em autonomia, quando seu exercício se dá por meio do princípio majoritário. Mas, no campo da teoria do direito, a ênfase que esse autor dá às normas jurídicas secundárias ilumina as reflexões sobre o papel que, de fato, ele atribui à regra da maioria.

Por fim, vale dizer que, para além de sua importância no tocante aos propósitos deste trabalho, a reflexão sobre as relações entre democracia e liberalismo está no centro de uma série de indagações bastante atuais no âmbito do constitucionalismo moderno.

Com quem deve estar a última palavra sobre os direitos e deveres que regem a vida em sociedade? As decisões tomadas pelo povo, por meio de seus representantes, podem ser invalidadas por uma corte de juízes togados? É antidemocrática a instituição de uma lista de direitos individuais que o povo não pode alterar e que deve ser interpretada por uma corte constitucional? Todas essas questões põem em dúvida a legitimidade do controle judicial de constitucionalidade vigente em muitas democracias contemporâneas. Há quem diga que fere os anseios democráticos atribuir a juízes não eleitos a função de decidir, em última instância, sobre os direitos: todos os membros da sociedade devem participar igualmente dessa decisão e o meio de se fazer isso é recorrer ao princípio majoritário. Outros, no entanto, defendem a revisão judicial da legislação, apontando o perigo que a regra da maioria representa à liberdade individual. Para eles, a rigidez constitucional oferece uma proteção contra a tendência tirânica do princípio majoritário e contra o relativismo filosófico a ele inerente.

Embora não estejamos preocupados aqui em estabelecer quais desses argumentos são mais probantes ou persuasivos, importa reconhecer o quanto um debate atual como esse pode ser visto como apenas uma nova abordagem do velho problema levantado por Constant. Nesse ponto vale observar, também, o quanto as alegações constitucionalistas em favor da revisão judicial sofreram influência dos argumentos garantistas de John Stuart Mill, em relação às liberdades individuais. 


\section{CAPÍTULO III - LIBERDADE E VERDADE}

Respondeu Jesus: "Sim. Para isso nasci, para isso vim ao mundo, para dar testemunho da verdade".

Disse-lhe Pilatos: "O que é a verdade?"

(Jo, 37-38)

\section{1 - Verdade racional}

A distinção entre verdade fatual e verdade racional é mencionada por Hannah Arendt em um ensaio sobre as relações entre verdade e política ${ }^{207}$. Nele, Arendt preocupa-se em demonstrar a importância da verdade fatual e sua fragilidade ante os assédios do poder: no âmbito da política, o testemunho de fatos é logo confundido com a mera opinião sobre eles e a verdade fatual não demora a se desvanecer. A verdade que se alcança por meio da reflexão racional é bem diferente: ela não corre o risco de desaparecer com o esquecimento, pois, ao contrário da verdade fatual, ela pode ser demonstrada - daí o fascínio pela verdade racional, do qual falamos no capítulo anterior. Apesar dessa diferença, Hannah Arendt reconhece que o conflito entre verdade e política surgiu inicialmente como um problema da verdade racional e é disso que trataremos no presente capítulo.

$\mathrm{Na}$ primeira parte deste capítulo, examinaremos de que modo o difícil convívio entre verdade racional e liberdade individual recebeu das teorias democráticas um

207 ARENDT, Hannah. "Verdade e política". In: Entre o passado e o futuro. Traduzido por Mauro W. Barbosa de Almeida. 2. ed. São Paulo: Editora Perspectiva, 1972, pp. 282-325. 
tratamento mais adequado. Na segunda parte, exporemos as virtudes da teoria de John Stuart Mill, que, embora tenha vislumbrado um meio de conciliar liberdade e democracia, acabou encontrando dificuldades para administrar as demandas de seu racionalismo.

\section{2 - O Iluminismo: a centralidade da ciência e dos direitos individuais}

Várias correntes de pensamento distintas, mas sobrepostas, compunham o movimento filosófico que se convencionou chamar Iluminismo. Todas essas correntes tinham em comum "a fé no poder da razão humana de compreender nossa verdadeira natureza e a natureza de nossas circunstâncias" 208 e a ideia de que o progresso humano pode ser alcançado por meio dessa compreensão. Esse ideal, é verdade, não surgiu com o movimento iluminista, o qual deita raízes no século XVII. Compreender a realidade por meio da razão é certamente uma pretensão mais antiga que o Iluminismo. Tão antiga quanto a insistência em se usar o conhecimento a serviço do progresso humano. Segundo Ian Shapiro, o que o Iluminismo trouxe como novidade é seu modo peculiar de entender a razão e o progresso humanos. Para o Iluminismo, "a busca de conhecimento empreendida pela razão é mediada pela ciência e alcançada por intermédio dela; e o critério para medir o progresso humano são os direitos individuais que personificam e protegem a liberdade humana"209.

Vamos entender melhor essa afirmação de Ian Shapiro.

Segundo esse autor, a preocupação com a ciência e com a liberdade são elementos novos trazidos pelo Iluminismo e colocados no centro de suas preocupações. A centralidade da ciência espelha a necessidade de um meio racional e seguro para se chegar às respostas certas a respeito do mundo e da natureza humana. A ciência era vista como o instrumento mais hábil a transformar o universo de acordo com as aspirações humanas ${ }^{210}$. Daí a valorização pelos teóricos iluministas de disciplinas como a lógica e a matemática.

\footnotetext{
${ }^{208}$ SHAPIRO, Ian. Os fundamentos morais da política. Traduzido por Fernando Santos. São Paulo: Martins Fontes, 2006, p. 9. Boa parte da tese de Shapiro sobre o Iluminismo está baseada na obra de Jonathan Israel, em que este último oferece uma exposição bastante abrangente daquele movimento intelectual, especialmente sobre o período que compreende os séculos XVII e XVIII. ISRAEL, Jonathan I.. Iluminismo Radical: a filosofia e a construção da modernidade, 1650-1750. Traduzido por Claudio Blanc. São Paulo: Madras, 2009.

${ }^{209}$ SHAPIRO, Ian. Os fundamentos morais da politica. Op. cit., p. 10.

${ }^{210}$ SHAPIRO, Ian. Os fundamentos morais da política. Op. cit., p. 11.
} 
Por outro lado, a centralidade dos direitos humanos desenvolveu-se a partir do contratualismo lockeano e, desde então, espelha a necessidade de se proteger a liberdade individual em face dos governos. Numa obra em que se discorre sobre a justificação dos Estados modernos, John Locke coloca em primeiro plano a existência de liberdades individuais fundamentais informadas pelo Direito Natural ${ }^{211}$.

Segundo Shapiro, no entanto, logo se percebeu uma tensão entre os dois elementos centrais do pensamento iluminista. A ciência preocupa-se em descobrir as leis que regem o universo. É, portanto, como já observamos, um “empreendimento determinista". O comprometimento com os direitos individuais, por outro lado, apenas tem razão de ser em face da liberdade de que gozam as ações humanas. Trata-se, como se vê, de outra forma da mesma perplexidade a que já nos referimos em 2.1.1.2, quando tratamos da tensão entre livre-arbítrio e determinismo.

Como observa Shapiro, John Locke não deixa de demonstrar certa dificuldade para conciliar sua convicção de que é possível descobrir as repostas sobre o direito natural - repleto de leis necessárias e definitivas a regerem o agir humano - com sua conviç̧ão de que os homens são livres para se conduzirem conforme sua vontade. Já havia se mostrado pouco à vontade em defender a imutabilidade do direito natural em face da onipotência do Criador (Não pode um Deus todo-poderoso alterar suas próprias leis?), mas a questão da liberdade humana colocava-o diante do típico problema agostiniano de confrontar pré-ciência divina com as indetermináveis possibilidades da vontade livre. E isso trazia dificuldades para a sua própria teoria política ${ }^{212}$.

É verdade que o Iluminismo deu nova roupagem ao velho dilema entre determinismo e livre-arbítrio, expondo-o, em bases laicas, como um dilema entre ciência (a busca por respostas certas e necessárias) e liberdade (o reconhecimento da contingência).

Mas era justamente no campo da fundamentação política que essas duas preocupações do Iluminismo chocavam-se com mais intensidade. Ian Shapiro resume esse paradoxo: "Se há respostas incontestavelmente certas acerca da legitimidade política, as quais toda pessoa de mente arejada deve confirmar, em que sentido as pessoas realmente têm o direito de decidir isso por elas próprias? Mas se, com base em suas próprias

${ }^{211}$ LOCKE, John. Dois Tratados sobre o Governo. Traduzido por Julio Fischer; rev. técnica de Renato Janine Ribeiro. São Paulo: Martins Fontes, 2005, pp. 437-439.

${ }^{212}$ SHAPIRO, Ian. Os fundamentos morais da politica. Op. cit., p. 21. 
convicções, elas são livres para rejeitar o que a ciência revela, o que resta então da reivindicação desta de que tem precedência diante de outros modos de envolvimento com o mundo?"213. Como vimos no capítulo anterior, o ideal racionalista parece incompatível com a ideia de liberdade humana ${ }^{214}$.

Os teóricos iluministas - e as correntes filosóficas que do Iluminismo sofreram demasiada influência - sempre tiveram de enfrentar essa dificuldade na elaboração de suas teorias políticas. No entanto, em seu amadurecimento, o Iluminismo desfez-se de falhas que seus detratores sempre apontaram. A principal delas era a crença na infalibilidade da ciência.

\subsection{1 - Os adversários do Iluminismo}

Para Ian Shapiro, malgrado as inúmeras diferenças entre os teóricos antiiluministas - "que vão dos tradicionalistas, como Edmund Burke (1729-1797), aos diversos teóricos pós-modernos e comunitaristas da literatura contemporânea" - todos têm em comum um ceticismo e, às vezes, até certa hostilidade, em relação às duas maiores crenças iluministas: a possibilidade de "racionalizar a política segundo orientações científicas" e a "ideia de que as liberdades personificadas nos direitos individuais são o valor político mais importante" 215 .

De um lado, percebem claramente a falibilidade do conhecimento científico e, por isso, criticam o racionalismo arrogante dos iluministas. De outro, especialmente no que tange à corrente comunitarista, compreendem a busca iluminista por direitos humanos fundamentais como incompatível com a pluralidade de fontes morais a que se ligam as diversas sociedades. Consideram insensata, portanto, a pretensão iluminista de que as liberdades fundamentais sejam protegidas da política.

Autores amiúde identificados com o comunitarismo, como Michael Walzer e Charles Taylor, tendem a defender a ideia de que as fontes do self "estão enraizadas em sistemas de afeição e afiliação que precedem os indivíduos e sobrevivem a eles, moldando

\footnotetext{
${ }^{213}$ SHAPIRO, Ian. Os fundamentos morais da politica. Op. cit., p. 22.

214 Veja-se no item 2.2.2.1, tópico "b", a alerta de Berlin: nenhum homem racional rejeitaria observar mandamentos provenientes de uma ordem inteiramente racional.

${ }^{215}$ SHAPIRO, Ian. Os fundamentos morais da politica. Op. cit., p. 6.
} 
suas expectativas de legitimidade política"216; afirmam que é impossível traçar um único princípio de justiça a reger os diversos sistemas de uma mesma $\operatorname{sociedade}^{217}$ e que é igualmente impossível a elaboração de princípios de justiça, sem se levar em conta a cultura de cada comunidade, a história de seus membros e a maneira variada como eles interpretam os diversos bens sociais ${ }^{218}$.

Sob tal perspectiva, uma declaração universal de direitos humanos não parece fazer sentido:

\begin{abstract}
A tentativa de produzir uma teoria completa da justiça ou uma defesa da igualdade por meio dos direitos logo transforma em farsa aquilo que multiplica. Dizer, de qualquer coisa que acreditemos que as pessoas devem ter, que têm o direito de tê-lo não é dizer muito. Os seres humanos têm, de fato, direitos que transcendem a vida e a liberdade, mas eles não provêm da humanidade que temos em comum; provêm de conceitos compartilhados de bens sociais; são locais e particulares em caráter ${ }^{219}$.
\end{abstract}

Para retomar a discussão mantida na seção 1.5.3, é de se notar um tom relativista na teoria de Walzer - que, de certo modo, até ele próprio reconhece: “A justiça é relativa aos significados sociais" ${ }^{, 220}$. Cuida-se, entretanto, de um relativismo moderado - se é que podemos chamá-lo assim. Walzer afirma que não é possível traçar - como quer, por exemplo, o utilitarismo - um único princípio de justiça para a pluralidade de esferas da vida social. Seu esforço em toda a obra é para demonstrar que é possível definir os princípios mais adequados para cada uma delas ${ }^{221}$.

Mas, e se houver, no seio da sociedade, desacordos sobre quais princípios são mais adequados em cada esfera?

\footnotetext{
${ }^{216}$ SHAPIRO, Ian. Os fundamentos morais da política. Op. cit., p. 7. Ver também TAYLOR, Charles. As fontes do self - A construção da identidade moderna. Traduzido por Adail Ubirajara Sobral e Dinah de Abreu Azevedo. São Paulo: Edições Loyola, 1997, pp. 15-40, 125-145 e 633-664.

${ }^{217}$ WALZER, Michael. Esferas da Justiça: uma defesa do pluralismo e da igualdade. Traduzido por Jussara Simões. São Paulo: Martins Fontes, 2003, pp. 3-5 e pp. 437-438

${ }^{218}$ WALZER, Michael. Esferas da Justiça... Op. cit., p. 5 e pp. 429-441.

${ }^{219}$ WALZER, Michael. Esferas da Justiça... Op. cit., p. XIX.

${ }^{220}$ WALZER, Michael. Esferas da Justiça... Op. cit., p. 429.

${ }^{221}$ WALZER, Michael. Esferas da Justiça... Op. cit., pp. 01-05 e pp. 429-441. Nesse aspecto, é possível notar uma proximidade entre o pluralismo defendido por Walzer e aquele defendido por Isaiah Berlin.
} 
A posição anti-iluminista não desenvolve uma resposta adequada para a questão de como resolver o problema da discordância sobre princípios. Shapiro demonstra de maneira bastante clara que o recurso a vínculos comunitários e tradições herdadas para a composição do que pode ser considerado um governo legítimo vem acompanhado de inúmeras dificuldades. Interpretações conflitantes das tradições e práticas consagradas acabam por exigir a existência de procedimentos aptos a determinar quais reivindicações devem prevalecer. Além disso, o movimento anti-iluminista não se sente à vontade diante de práticas consideradas ilegítimas pela maioria das teorias políticas e que somente são grosseiramente justificadas com base no costume vigente. Assim, no que se refere à centralidade dos direitos humanos, a crítica anti-iluminista não oferece nenhuma resposta convincente ${ }^{222}$.

Quanto ao compromisso com a busca de certezas por meio da ciência, a resposta de Shapiro é ainda mais incisiva: trata-se de uma crítica que até faz sentido quando dirigida ao Iluminismo primitivo, mas que não logra qualquer êxito quando destinada ao Iluminismo maduro.

Segundo Shapiro, no Iluminismo maduro, a fé na busca da verdade pela ciência adquiriu novos contornos. A tradição iluminista pós-Hume "tem sido marcada por uma visão falibilista do conhecimento. Segundo essa concepção, todas as afirmações do conhecimento são falíveis, e não é tornando este mais seguro que a ciência avança, e sim produzindo mais conhecimento"223. A moderna postura científica reconhece, pois, a susceptibilidade da razão humana ao engano. As relevantes observações de Karl Raimund Popper sobre a importância da crítica racional e sobre a importância de se reconhecer que sempre podemos estar enganados exemplificam primorosamente o modus operandi do Iluminismo maduro: quando as hipóteses sobrevivem aos testes empíricos, o máximo que podemos dizer "é que a falsidade delas não ficou provada, de forma que podemos aceitá-la provisoriamente" 224 . Todo conhecimento é verdadeiro apenas hipoteticamente; nunca pode ser garantido de uma vez por todas. Mas esse fato não conduz a ciência ao descrédito diante do Iluminismo. Por meio da livre discussão e do exame crítico, "podemos

${ }^{222}$ SHAPIRO, Ian. Os fundamentos morais da política. Op. cit., pp. 225-243.

${ }^{223}$ SHAPIRO, Ian. Os fundamentos morais da política. Op. cit., p. 16.

${ }^{224}$ SHAPIRO, Ian. Os fundamentos morais da política. Op. cit., p. 16. 
reconhecer em tempo falhas e fraquezas em nossos conhecimentos e convicções, eliminálas e desse modo melhorar continuadamente nosso conhecimento e nossas convicções"225.

Sob a perspectiva do Iluminismo maduro, o reconhecimento de que as alegações de verdade sempre podem ser passíveis de correção "é um sinal de superioridade da ciência sobre a opinião, as convenções, a superstição e a tradição, não um sinal de que seja equivalente a elas"226. A ciência política não é diferente.

A posição anti-iluminista não crê que a ciência possa orientar a política. Shapiro discorre algumas páginas sobre contribuições da ciência política para a compreensão de importantes instituições e arranjos políticos. Mostra, por exemplo, os avanços obtidos na compreensão das relações existentes entre estabilidade democrática e desenvolvimento econômico ou na constatação dos reais custos provenientes de uma suposta ineficiência das instituições democráticas ${ }^{227}$. Na verdade, Shapiro quer nos convencer de que as deficiências e limitações da ciência política não obstam sua grande contribuição para o "avanço crescente do conhecimento a respeito da política"228. Mais: segundo ele, o compromisso com a ciência "implica resistência aos argumentos vindos do poder ou do interesse" 229 , de modo que o etos do Iluminismo fornece melhores meios de lidar com a dinâmica da política.

Por fim, Shapiro não deixa de consignar que esse ceticismo da posição antiiluminista quanto às contribuições da ciência para a orientação do curso político tem o efeito de inviabilizar a busca por critérios satisfatórios de avaliação da legitimidade política $^{230}$.

Vimos, portanto, que, ao refutar as importantes críticas anti-iluministas, Shapiro expôs o valor de um Iluminismo amadurecido, consciente da falibilidade humana na busca pela verdade (e, por isso, menos arrogante que sua versão primitiva) e atento, no campo da política, para o fato de que nem sempre haverá agentes comprometidos com a

\footnotetext{
${ }^{225}$ SALAMUN, Kurt. "Karl R. Popper - Etos iluminista e racionalidade crítica”. In: HENNIGFELD, Jochem e JANSOHN, Heinz (organizadores). Filósofos da atualidade. Traduzido por Ilson Kayser. São Leopoldo, RS: Editora UNISINOS, 2006, p. 78.

${ }^{226}$ SHAPIRO, Ian. Os fundamentos morais da política. Op. cit., p. 201.

${ }^{227}$ SHAPIRO, Ian. Os fundamentos morais da política. Op. cit., pp. 211-216.

${ }^{228}$ SHAPIRO, Ian. Os fundamentos morais da política. Op. cit., p. 216.

${ }^{229}$ SHAPIRO, Ian. Os fundamentos morais da política. Op. cit., p. 217. Na mesma página: "Com frequência, implica o reconhecimento de que não sabemos a resposta certa, mesmo enquanto desmascaramos afirmações falsas feitas por aqueles que alegam conhecê-la. Desistir da postura científica é desistir disso".

${ }^{230}$ SHAPIRO, Ian. Os fundamentos morais da política. Op. cit., p. 218.
} 
verdade. Como veremos adiante, das tradições filosóficas que elaboraram teorias de legitimação do Estado, saiu-se melhor aquela que, ainda hoje, guarda mais afinidade com esse Iluminismo maduro: a democracia.

\subsection{2 - As filhas do Iluminismo}

Que governos merecem nossa lealdade? Para desenvolver seu estudo, Ian Shapiro nos mostra que três tradições filosóficas bastante distintas - utilitarismo, contratualismo e marxismo - buscaram, cada uma a seu modo, oferecer uma resposta a essa indagação.

Para os utilitaristas clássicos, a legitimidade de um governo está associada à "sua vontade e capacidade" de maximizar a maior felicidade do maior número de pessoas $^{231}$. É verdade, diz Shapiro, que os utilitaristas não estão de acordo sobre o que deve ser entendido por felicidade, ou como se pode medi-la, mas, em geral, concordam com variações dessa ideia. John Stuart Mill foi um grande defensor do utilitarismo. Porém, para estabelecer a legitimidade de um Estado, Mill combinou sua teoria utilitarista com as limitações impostas por seu princípio do dano.

Quanto ao contratualismo, há várias formas pelas quais ele se apresenta. Em comum, todas postulam que a legitimidade de um governo baseia-se na celebração de um acordo. A tradição do contrato social remonta à antiguidade, mas sua configuração moderna deve-se aos trabalhos contratualistas escritos a partir de Hobbes. Embora discordem sobre a natureza do acordo celebrado, sobre as partes que o celebram e sobre a forma de implementá-lo, os autores contratualistas - mesmo nos modernos escritos de Rawls e Dworkin - concordam em que a fonte de legitimidade do Estado é alguma forma de consentimento dos governados. Na verdade, os contratualistas do século XX passaram a recorrer à noção de contrato hipotético: a partir desses autores, a legitimidade do governo passou a apoiar-se não em um acordo real, mas na racionalidade daquilo que teria sido acordado em circunstâncias imaginadas por esses autores ${ }^{232}$.

${ }^{231}$ SHAPIRO, Ian. Os fundamentos morais da politica. Op. cit., p. 04.

${ }^{232}$ SHAPIRO, Ian. Os fundamentos morais da politica. Op. cit., p. 05 e pp. 141-147. 
As correntes marxistas, por sua vez, têm em comum a ideia de que um governo que promove ou permite a exploração dos governados carece de legitimação. Merecem a lealdade dos governados apenas os governos que promovem a antítese da exploração, isto é, a liberdade humana. É evidente que as tantas linhagens marxistas discordam quanto àquilo em que consiste a exploração dos indivíduos, ou quanto ao papel dos governos para a eliminação da exploração.

Uma das principais ideias defendidas por Shapiro, em sua obra Os fundamentos morais da política, é a de que essas três tradições filosóficas têm muito em comum, porque foram igualmente moldadas pelos valores do pensamento Iluminista. Foram moldadas de maneira tão decisiva que cada uma delas carrega em si as duas grandes preocupações iluministas acima referidas. Na verdade, o grande desafio de Shapiro não está em demonstrar a forte influência do Iluminismo sobre tais tradições, mas em demonstrar que elas são de tal modo irmãs que padecem exatamente das mesmas falhas em suas respectivas teorias de fundamentação do Estado. Para Shapiro, todas falham ao administrar a tensão existente entre os valores da certeza científica e da liberdade humana. Segundo ele, a nota que aproxima todas essas tradições filosóficas - e que indica terem sido forjadas no calor do movimento iluminista - é a crença no racionalismo científíco e a preocupação com a liberdade. Em todas essas correntes filosóficas está presente, no campo da teoria política, a ideia de que se pode chegar, por meio da razão, a respostas certas acerca dos arranjos políticos. Em todas, vê-se a liberdade como um valor a ser perseguido. Nesse aspecto, as teorias contratualistas exemplificam de maneira sintética a influência do Iluminismo: para o contratualismo, em regra, as partes celebrantes do contrato são pessoas, ao mesmo tempo, racionais e livres ${ }^{233}$.

Nessa obra, Shapiro dedica alguns capítulos para apontar os erros nos quais incorrem referidas tradições fillosóficas. Infelizmente, não há espaço neste estudo para examinarmos as interessantes críticas que ele destina às correntes do marxismo e do contratualismo - em especial, a profunda análise que faz do contratualismo de John Rawls, que ele considera o mais consequente dos teóricos do contrato social, e em cujos argumentos vê uma importante e inovadora contribuição para a justificação do Estado. Ante tal dificuldade, voltaremos nossa atenção à análise que Ian Shapiro faz da teoria milliana.

${ }^{233}$ SHAPIRO, Ian. Os fundamentos morais da política. Op. cit., pp. 143-145. 


\section{3 - A teoria de John Stuart Mill}

A tese de Ian Shapiro é relativamente simples no que toca ao princípio do dano: trata-se de um princípio elaborado a partir do comprometimento de John Stuart Mill com aqueles dois valores básicos do Iluminismo. A preocupação com as liberdades individuais está claramente embutida nesse princípio e o racionalismo científico é de todo evidente em sua teoria utilitarista ${ }^{234}$. Resta saber de que forma Mill procura harmonizar essas preocupações.

Para tanto, vale recordar, em primeiro lugar, o papel do individualismo no arcabouço teórico de nosso autor.

Stuart Mill diz expressamente acreditar no valor intrínseco da espontaneidade individual ${ }^{235}$. É bastante conhecida sua insistência "na importância do gênio e na necessidade de lhe permitir desenvolver-se livremente tanto em pensamento como na prática" ${ }^{236}$. Conforme já tínhamos observado em 2.2.1.1, Mill defende a liberdade como condição necessária para o desenvolvimento da genialidade e da espontaneidade e para o florescimento natural da verdade. De fato, segundo ele, a promoção da liberdade individual é o caminho mais seguro para a expansão do conhecimento. No fundo, Stuart Mill não acreditava na "força expansiva da verdade"237: para ele, é uma completa ingenuidade acreditar que a verdade sempre sobreviverá às perseguições ${ }^{238}$. Por isso, Mill apresenta-se como ferrenho defensor da liberdade de expressão e da livre disputa de ideias $^{239}$. Ao arrolar argumentos em prol da liberdade de expressão, Mill deixa clara sua visão falibilista do conhecimento. Além de aproximá-lo do chamado Iluminismo maduro,

\footnotetext{
${ }^{234}$ SHAPIRO, Ian. Os fundamentos morais da política. Op. cit., pp. 72-73.

${ }^{235}$ MILL, John Stuart. A liberdade / Utilitarismo. Traduzido por Eunice Ostrensky. São Paulo: Martins Fontes, 2000, p. 87.

${ }^{236}$ MILL, John Stuart. A liberdade / Utilitarismo. Op. cit., 100. Sobre tal afirmação, ver também FEINBERG, Joel. Filosofia social. Traduzido por Alzira Soares da Rocha e Helena Maria Camacho. Rio de Janeiro: Zahar Editores, 1974, p. 40.

${ }^{237}$ A crença na força expansiva da liberdade é um dos argumentos usados por Bobbio para demonstrar que é possível ser tolerante sem ser cético, num texto primoroso sobre a relação entre liberdade e verdade. Nesse texto, Bobbio mostra que há argumentos nesse sentido tanto para os que têm uma concepção monista da verdade quanto para os que têm uma visão pluralista. BOBBIO, Norberto. "Verdade e liberdade". In: Elogio da serenidade e outros escritos morais. Traduzido por Marco Aurélio Nogueira. São Paulo: Editora UNESP, 2002, pp. 137-148.

${ }^{238}$ MILL, John Stuart. A liberdade / Utilitarismo. Op. cit., pp. 45-46.

${ }^{239}$ LAFER, Celso. Ensaios Liberais. São Paulo: Siciliano, 1991, pp. 69-70.
} 
essa visão falibilista apresenta a liberdade como um instrumento essencial da atividade científica $^{240}$.

Por outro lado, Mill dizia ser a utilidade "a solução última de todas as questões éticas". Para ele, entretanto, a utilidade deveria estar "fundamentada nos interesses permanentes do homem como um ser de progresso" ${ }^{241}$. Segundo Ian Shapiro, Mill acreditava que a ciência é o instrumento por meio do qual tais interesses podem ser descobertos: a ciência era vital para o progresso utilitarista e a liberdade individual especialmente a liberdade de expressão - era vital para o desenvolvimento da ciência ${ }^{242}$. Daí a íntima conexão entre a defesa da liberdade, por meio de princípio do dano, e sua profissão de fé utilitarista.

No entanto, a tensão entre os conflitantes valores Iluministas (liberdade e ciência) não demora a aparecer. Um exemplo disso é a questão da educação. No contexto de sua defesa do pluralismo intelectual, é bastante conhecido o receio de Mill quanto aos riscos do "conformismo socialmente imposto por uma opinião majoritária"243, receio este amplamente exposto ao longo do mesmo capítulo em que ele exalta a individualidade humana ${ }^{244}$. Pois bem. Se, na atmosfera de exaltação da ciência, a educação tinha papel singular - a ponto de Stuart Mill dizer que o Estado deveria impor aos pais o dever de educar seus filhos ${ }^{245}$ - Mill parece reconhecer, não obstante, que a educação, por submeter as pessoas a influências comuns, pode ter como efeito justamente o nocivo nivelamento dos indivíduos ${ }^{246}$. Como veremos adiante, esse conflito reaparece algumas vezes ao longo de sua obra, sem que Mill consiga dar-lhe uma solução satisfatória ${ }^{247}$. Às vezes, tem mais peso sua crença num racionalismo capaz de obter as verdadeiras respostas sobre os complexos problemas humanos. Às vezes, o que pesa mais é sua visão falibilista do conhecimento humano e a decorrente necessidade de se protegerem as liberdades individuais.

\footnotetext{
${ }^{240}$ MILL, John Stuart. A liberdade / Utilitarismo. Op. cit., pp. 80-81. Também SHAPIRO, Ian. Os fundamentos morais da política. Op. cit., pp. 73-74.

${ }^{241}$ MILL, John Stuart. A liberdade / Utilitarismo. Op. cit., p. 19.

${ }^{242}$ SHAPIRO, Ian. Os fundamentos morais da politica. Op. cit., p. 73.

${ }^{243}$ LAFER, Celso. Ensaios Liberais. São Paulo: Siciliano, 1991, p. 70.

${ }^{244}$ MILL, John Stuart. A liberdade / Utilitarismo. Op. cit., pp. 85-113.

${ }^{245}$ MILL, John Stuart. A liberdade / Utilitarismo. Op. cit., pp. 159-160.

${ }^{246}$ MILL, John Stuart. A liberdade / Utilitarismo. Op. cit., p. 112.

${ }^{247}$ SHAPIRO, Ian. Os fundamentos morais da politica. Op. cit., p. 75.
} 
À vista dessas dificuldades, é curioso que John Stuart Mill tenha legado aos estudiosos um ensaio cuja pretensão mais evidente era justamente a de anunciar um princípio liberal perfeitamente acoplado àquela que ele considerava a teoria política mais racional e promissora de seu tempo: o utilitarismo.

\subsection{1 - O utilitarismo}

O utilitarismo é uma teoria consequencialista ${ }^{248}$. Uma teoria segundo a qual a justiça ou injustiça de determinada ação dependem precisamente das consequências que tal ação pode determinar ${ }^{249}$. O utilitarismo, afirma Stuart Mill, sustenta que "as ações são corretas na medida em que tendem a promover a felicidade e erradas conforme tendam a produzir o contrário da felicidade. Por felicidade, se entende prazer e ausência de dor; por infelicidade, dor e a privação do prazer" ${ }^{, 50}$. Desde que Jeremy Bentham baseou sua doutrina na consideração de que o ser humano é permanentemente escravo de dois senhores $^{251}$ - o prazer e a dor -, o utilitarismo tem sido identificado com a ideia de que o justo é propiciar a maior felicidade para o maior número de pessoas. Todavia, cumpre acrescentar algo: para os utilitaristas, é axiomático que a felicidade de uma pessoa deva ser considerada tanto quanto a de todas as outras, de modo que cada indivíduo valha por um e somente um, na ponderação dos interesses envolvidos ${ }^{252}$.

\footnotetext{
${ }^{248}$ Sobre o utilitarismo como uma espécie de consequencialismo, ver SHAPIRO, Ian. Os fundamentos morais da política. Op. cit., p. 33 e SINGER, Peter. Ética Prática. Traduzido por Jeferson Luiz Camargo. 3. ed. São Paulo: Martins Fontes, 2002, p. 11.

${ }^{249}$ Consoante Jeremy Bentham, a base do utilitarismo é o princípio da utilidade: "princípio que aprova ou desaprova toda e qualquer ação, segundo a tendência que parece ter para aumentar ou diminuir a felicidade da parte cujo interesse está em questão", BENTHAM, Jeremy. Uma introdução aos princípios da moral e da legislação. In: MORRIS, Clarence. Os grandes filósofos do direito: leituras escolhidas. Traduzido por Reinaldo Guarany. São Paulo: Ed. Martins Fontes, 2002, p. 262.

${ }^{250}$ MILL, John Stuart. A liberdade / Utilitarismo. Op. cit., p. 187. Já se sugeriu que os utilitaristas clássicos, Bentham e Mill, usavam os termos "prazer" e "dor" de um modo amplo o suficiente para se incluir no campo de considerações utilitárias todos os interesses e preferências das pessoas afetadas pela ação que se pretende analisar. SINGER, Peter. Ética Prática. Op. Cit., p. 22.

${ }^{251}$ BENTHAM, Jeremy. Uma introdução aos princípios da moral e da legislação. Op. Cit., p. 261.

${ }^{252}$ Stuart Mill afirma que tal princípio está "compreendido no próprio significado da palavra Utilidade ou Princípio da Maior Felicidade”. MILL, John Stuart. A liberdade / Utilitarismo. Op. cit., p. 273. É vasta a literatura que descreve essa característica da teoria utilitarista. Sobre a importância desse "princípio de imparcialidade" na obra de Mill, veja-se GUISÁN, Esperanza. "Esperando por Mill". Traduzido por Rita de Cássia Lana. In: PELUSO, Luis Alberto (org.). Ética e utilitarismo. Campinas: Editora Alínea, 1998, pp. 115-116. Peter Singer foi um dos autores que mais enfatizaram esse princípio na ética utilitária, chamando-o de "princípio da igual consideração dos interesses". SINGER, Peter. Ética Prática. Op. Cit., pp. 25-35.
} 
Embora atrativo, o utilitarismo tem sido alvo de frequentes objeções ao longo da história. A primeira entre as que se devem mencionar é a que Alf Ross chamou de "incomensurabilidade qualitativa das necessidades"253. Conforme essa objeção, se o utilitarismo preocupa-se em aumentar a felicidade geral das pessoas que serão afetadas por uma decisão moral, então o cálculo utilitarista é inviável na prática. Porque é praticamente impossível mensurar e comparar, com exatidão, o grau de felicidade e os interesses de cada uma das pessoas envolvidas em determinada situação. A isso, um dos maiores defensores contemporâneos do utilitarismo, o filósofo australiano Peter Singer, responde que, na comparação das preferências e interesses envolvidos, a precisão não é fundamental para se ter um agir moralmente correto $^{254}$.

Outra objeção muito comum é aquela que aponta o modo de vida insuportavelmente calculista gerado pelo utilitarismo: para cada decisão a ser tomada, é necessário um profundo raciocínio moral que, de tão complexo, é, às vezes, infactível. O utilitarismo exige que calculemos se as consequências de nossos atos contribuirão para o aumento da felicidade geral, mas, na maioria dos casos, é impossível prever todas as consequências que uma ação pode gerar ${ }^{255}$.

Na verdade, os utilitaristas reconhecem que não é nada prático tentar prever todas as consequências das escolhas que fazemos. Na maioria dos casos, em vez de tentarmos calcular os efeitos de cada atitude moral antes de tomá-la, é melhor que nos guiemos por um conjunto de princípios escolhidos previamente e de acordo com critérios utilitaristas. Daí nasce uma distinção importante. O raciocínio moral pode ocorrer em dois níveis - o nível crítico e o nível intuitivo. No nível crítico, examinam-se, detida e cuidadosamente, todas as circunstâncias e interesses envolvidos no caso específico, com vistas a se decidir por uma ação que produza as melhores consequências. Já o raciocínio em nível intuitivo, busca orientar-se por amplos princípios éticos que a experiência histórica demonstrou serem mais aptos à produção dos melhores resultados e mais propensos a maximizar a felicidade do maior número de indivíduos. Assim, regras básicas como as que nos orientam a cumprir promessas, não lesar a terceiros, dizer a verdade,

\footnotetext{
${ }^{253}$ ROSS, Alf. Direito e Justiça. Trad. ao português, a partir da versão inglesa, por Edson Bini. Bauru, SP: EDIPRO, 2000, pp. 335-342.

${ }_{254}^{254}$ SINGER, Peter. Ética Prática. Op. Cit., p. 71.

${ }^{255} \mathrm{Ou}$, como afirma Stuart Mill, tal objeção pode também enfatizar a escassez de tempo para o raciocínio moral: "Não há tempo, antes da ação, para calcular e pesar os efeitos de uma linha de conduta sobre a felicidade geral". MILL, John Stuart. A liberdade / Utilitarismo. Op. cit., p. 211.
} 
obedecer às leis, evidentemente, integram esse corpo de princípios ${ }^{256}$. Para fixar esse entendimento, John Stuart Mill afirmava: "Seja qual for o princípio moral que adotemos, necessitamos de princípios subordinados para aplicá-lo" ${ }^{\text {257 }}$. É bem verdade, porém, que a decisão tomada em conformidade com ditos princípios, muitas vezes, será diferente daquela tomada segundo o pensamento em nível crítico. E haverá casos, embora excepcionais, nos quais descumprir essas regras gerais será indiscutivelmente melhor do que segui-las - nessas situações, deve-se dizer, o raciocínio moral em nível crítico produzirá melhores resultados ${ }^{258}$.

Por fim, há uma última objeção à doutrina utilitarista que devemos mencionar. Trata-se da alegação segundo a qual o utilitarismo não reconhece a existência de direitos individuais fundamentais independentes do princípio da maior felicidade: para os utilitaristas não há limites à maximização da felicidade total. De fato, o próprio John Stuart Mill profere uma declaração famosa a esse respeito, quando diz renunciar às vantagens que possam porventura advir da ideia de "direito abstrato como independente da utilidade" ${ }^{259}$. Conforme ele próprio afirma, para todas as questões éticas, a utilidade é a solução em última instância. Mas Mill acreditava no dever da sociedade de proteger os direitos individuais - e, para ele, tal dever não tinha outra razão senão a "utilidade geral" ${ }^{\text {260 }}$. Com efeito, há razões utilitárias para a obediência às leis em geral. Quando transgrido uma norma legal, estou contribuindo, com meu exemplo, para que outras pessoas também pratiquem suas infrações; e a desobediência generalizada pode, no limite, ocasionar uma guerra civil, resultado que fatalmente reduziria a felicidade geral do povo a que pertenço. Assim, a obediência às leis civis parece ser um tipo de regra prática cuja observância, de um modo geral, contribui para maximizar a felicidade dos cidadãos ${ }^{261}$.

Entretanto, obedecer à lei e zelar por seu cumprimento são princípios vinculantes apenas enquanto raciocinamos em nível intuitivo. Se, em determinado caso, após uma análise em nível crítico, a transgressão de uma norma legal revela-se mais correta, o filósofo utilitarista não hesitará em defendê-la: a norma posta não guarda relação necessária com a moral e, quando os princípios subordinados conflitam com o primordial

\footnotetext{
${ }^{256}$ SINGER, Peter. Ética Prática. Op. cit., pp. 102-103.

${ }^{257}$ MILL, John Stuart. A liberdade / Utilitarismo. Op. cit., p. 213.

${ }^{258}$ SINGER, Peter. Ética Prática. Op. cit., p. 104.

${ }^{259}$ MILL, John Stuart. A liberdade / Utilitarismo. Op. cit., p. 19.

${ }^{260}$ MILL, John Stuart. A liberdade / Utilitarismo. Op. cit., p. 260.

${ }^{261}$ SINGER, Peter. Ética Prática. Op. cit., pp. 312-313.
} 
princípio da utilidade, é este último que deve prevalecer - pois, como vimos, "a utilidade é a fonte última das obrigações morais" ${ }^{262}$. Nesse sentido, pois, a desobediência civil apresenta-se como um dilema ético em que se confrontam, de um lado, a alegada imoralidade da norma jurídica e, de outro, o risco da desordem anárquica: sua justificativa passa necessariamente por uma análise em nível crítico do caso particular.

Quando o raciocínio utilitarista volta sua atenção para a moralidade das leis, ele deixa de ser apenas uma teoria sobre a moral e passa a ser também uma robusta teoria política. E no utilitarismo como teoria política, o princípio do dano tem papel preponderante.

\subsection{2 - O papel do dano na legitimação estatal}

É realmente difícil entender como Stuart Mill pôde defender a utilidade como resposta última das questões éticas e, ao mesmo tempo, postular o valor intrínseco da liberdade humana. George Sabine, que historiou o pensamento político de Mill, não deixou de observar essa aparente incoerência, afirmando que ela decorria da dificuldade pessoal de Mill em negar os dogmas utilitaristas com os quais fora educado, a despeito de ser esse o seu mais profundo desejo ${ }^{263}$.

À vista dessas dificuldades para se compreender a teoria de Mill, os estudos mais exaustivos têm-na apresentado como uma teoria complexa na qual o princípio do dano, embora diretamente derivado das premissas utilitaristas, atua como uma espécie de limite ao cálculo utilitário. Entre esses estudos está o de John Gray, pensador liberal que se empenhou em defender a coerência do pensamento milliano, demonstrando que as acusações relativas a esse tema eram fruto de compreensões simplistas acerca da doutrina de Mill, que não apreendiam a inteireza de suas ideias.

\footnotetext{
${ }^{262}$ MILL, John Stuart. A liberdade / Utilitarismo. Op. cit., p. 116.

263 "Sem muito exagero, poder-se-ia dizer que seus livros foram escritos segundo uma fórmula. Em quase todos os assuntos, ele provavelmente começaria com uma exposição geral de princípios que, tomados literalmente e por si mesmos, pareceriam tão rígidos e abstratos quanto qualquer coisa que seu pai pudesse ter escrito. Mas, tendo declarado lealdade aos dogmas ancestrais, Mill prosseguia fazendo concessões e reformulações de tão altas consequências que o leitor crítico ficava em dúvida se a declaração inicial não fora refutada". SABINE, George Holland. História das ideias políticas - Vol. 2. Traduzido por Ruy Jungmann. Rio de Janeiro: Fundo de Cultura, 1964, p. 686.
} 
Para John Gray, a doutrina da liberdade ensinada por Stuart Mill - tal como havíamos ponderado na seção anterior - repousa numa forma de utilitarismo que dá espaço a importantes princípios morais secundários que Gray denominou "utilitarismo indireto" ${ }^{264}$. Segundo ele, a doutrina de Mill postula conexões entre liberdade, autodesenvolvimento e felicidade - conexões essas que não são meramente casuais ou conceituais. Bem por isso, essa doutrina deve ser interpretada em harmonia com suas ideias sobre individualismo e liberdade. John Gray vê na obra de Mill elementos que estruturam um argumento robusto em favor do direito moral à liberdade: ponderações quanto ao efeito autodestrutivo de se apelar diretamente à utilidade; a ideia de que o indivíduo somente pode ser feliz quando exerce os poderes do livre pensamento e da livre ação; a convicção de que somente numa sociedade liberal os poderes do indivíduo podem ser plenamente desenvolvidos ${ }^{265}$. Diante de tais elementos, diz Gray, o princípio do dano que ele chama Princípio da Liberdade - embora deva ser entendido como um princípio secundário, constitui, na realidade, um imperativo que protege verdadeiro direito moral à liberdade: um direito que é revogável - como, de resto, são revogáveis, em regra, os direitos morais estabelecidos em teorias da justiça não-utilitaristas -, mas que não deve ser afastado, sempre que o cálculo das consequências sugerir que isso maximizará o bem-estar $\operatorname{total}^{266}$.

Na mesma linha, Ian Shapiro propõe uma interpretação bastante plausível de como o princípio do dano se harmoniza ao arcabouço utilitarista em que Mill se apoia. A certa altura de seu ensaio, Stuart Mill escreve:

Tão logo qualquer parte da conduta de alguém influencia de modo prejudicial os interesses de outros, a sociedade adquire jurisdição sobre tal conduta, e a questão de saber se essa interferência favorecerá ou não o bem-estar geral se abre à discussão ${ }^{267}$.

\footnotetext{
${ }^{264}$ GRAY, John. Mill on liberty: a defense. 2. ed. London: Routledge, 1996, p. 14.

${ }^{265}$ GRAY, John. Mill on liberty: a defense. Op. cit., pp. 15-16.

${ }^{266}$ GRAY, John. Mill on liberty: a defense. Op. cit., p. 16.

${ }^{267}$ MILL, John Stuart. A liberdade / Utilitarismo. Op. cit., p. 116. No original: “As soon as any part of a person's conduct affects prejudicially the interests of the others, society has jurisdiction over it, and the question whether the general welfare will or will not be promoted by interfering with it becomes open to discussion." MILL, John Stuart. Utilitarianism, Liberty and Representative Government. Londres: J. M. Dent \& Sons Ltd., 1910, p. 132.
} 
Ian Shapiro interpreta esse pequeno trecho como sendo um resumo elucidativo do princípio do dano e que sugere sua aplicação em duas etapas. Na primeira etapa, é necessário julgar se a ação ofende ou tem potencial para ofender a terceiros. Se a resposta for negativa, então a intervenção do governo não se justifica. Se, ao contrário, a resposta for positiva, então se inicia a etapa de considerações utilitaristas. Isto é: uma vez constatado que a ação ofende a outrem, passa-se ao domínio daquilo que é público. Nessa fase, a discussão não se limita aos meios de evitar o dano específico; discute-se também, e principalmente, qual a melhor política para a sociedade em geral - quais as decisões e ações governamentais aptas a maximizar a felicidade para o maior número de pessoas ${ }^{268}$. Como se observa, tal interpretação indica a prevalência do princípio do dano sobre o cálculo utilitarista, dado que é preciso verificar a observância do "Princípio da Liberdade", antes de se indagar acerca do bem-estar geral.

É preciso dizer, entretanto, que a compatibilidade entre o princípio do dano e seu utilitarismo não salva Stuart Mill de um apuro persistente: o problema de se definir quando uma ação causa danos a terceiros.

\subsection{3 - A aplicação do princípio do dano}

George Sabine apontou a obscuridade do critério usado por Mill e observou que o ensaio sobre $A$ liberdade perde muito de sua qualidade no momento em que Mill deixa de discorrer sobre o valor moral da liberdade e passa à tarefa prática de definir que limitações a sociedade ou o Estado podem impor ao indivíduo ${ }^{269}$.

A esse respeito, pode-se dizer que um dos problemas está na dificuldade de se delimitar conceitualmente o termo "dano". Muitos autores chamaram a atenção para o

\footnotetext{
${ }^{268}$ Nesse campo, é evidente a ênfase dada por John Stuart Mill a um utilitarismo das regras e não dos atos: o utilitarismo das regras preocupa-se em descobrir as normas de conduta cuja imposição contribui para promover o aumento da felicidade total; o utilitarismo dos atos, diversamente, preocupa-se com cada ação individual, examinando quais condutas contribuem mais para aquela promoção. SHAPIRO, Ian. Os fundamentos morais da política. Op. cit., p. 77. Sobre essa distinção, veja-se: HARSANYI, John C.. "Rule Utilitarianism and Decision Theory". In: Erkenntnis (1975-), Vol. 11, n. 1, Social Ethics, Part 1, 1977, pp. 29-33. Disponível em http://www.jstor/stable/20010532.

${ }^{269}$ SABINE, George Holland. História das ideias politicas - Vol. 2. Op. cit., p. 690. Sobre isso Ian Shapiro afirma: "Mill pode estar certo quando diz que a prevenção do dano é um critério importante para determinar a legitimidade da ação do Estado, mas seu princípio não diz quais são os danos relevantes para os diversos tipos de ação do Estado, como resolver as divergências acerca de tais questões ou até onde devem chegar as ações reparadoras do Estado", em SHAPIRO, Ian. Os fundamentos morais da política. Op. cit., p. 86.
} 
fato de que esse termo tem significados diversos, a depender do contexto em que é utilizado: é o que Ian Shapiro chamou de "variação contextual da definição de dano" Joel Feinberg já havia feito um trabalho importante ao tentar definir com mais precisão os possíveis significados para a palavra "dano" (em inglês, "harm”). Primeiramente, Feinberg elaborou uma distinção entre o que chamou "princípio do dano privado" (cujo objetivo é impedir danos a outras pessoas) e o "princípio do dano público" (que visa a impedir não simplesmente o dano direto, mas "o enfraquecimento das práticas institucionais e dos sistemas normativos de interesse público"), e explicou que Mill provavelmente defendia essas duas versões do princípio $^{271}$. Depois, Feinberg partiu para uma análise dos possíveis sentidos atribuídos ao termo usado por Mill ("harm”) e para um exame das especificidades que o distinguem de seus sinônimos "lesão" e "ofensa", buscando compreender por que razões Mill teria usado aquele, em detrimento destes ${ }^{272}$.

Como vimos, Feinberg defende a legitimidade de algumas práticas paternalistas ("paternalismo brando") e, nessa linha, propõe que o princípio do dano seja complementado de modo a contemplar alguma ponderação acerca da voluntariedade existente nas condutas examinadas ${ }^{273}$. Não obstante, ele assevera que mesmo a versão simples daquele princípio, em razão das mencionadas dificuldades semânticas inerentes à palavra "dano", "está longe de ser um guia preciso para o legislador ideal",274.

Também Jeremy Waldron, em um artigo de 1987, buscou compreender o alcance que Mill pretendeu dar à expressão "harm to others". Para Waldron, é evidente que a questão a ser colocada não deve circunscrever-se ao "real significado" da palavra "dano" - até porque, segundo ele, essa palavra não possui um "significado claro e indisputável, esperando por nossa análise" ${ }^{275}$. Não se trata, pois, de desvendar a correta concepção do termo, mas de identificar a concepção mais adequada aos propósitos para os quais o termo

\footnotetext{
${ }^{270}$ SHAPIRO, Ian. Os fundamentos morais da política. Op. cit., p. 80.

${ }^{271}$ FEINBERG, Joel. Filosofia social. Traduzido por Alzira Soares da Rocha e Helena Maria Camacho. Rio de Janeiro: Zahar Editores, 1974, pp. 46-47.

${ }^{272}$ FEINBERG, Joel. Filosofia social. Op. cit., pp. 47-54.

${ }^{273}$ FEINBERG, Joel. Filosofia social. Op. cit., pp. 77-82.

${ }^{274}$ FEINBERG, Joel. Filosofia social. Op. cit., pp. 47.

${ }^{275}$ WALDRON, Jeremy. "Mill and the Value of Moral Distress". In: Political Studies. Volume XXXV, no 03: Political Studies Association, 1987, pp. 413-414.
} 
foi empregado. Segundo Waldron, esses propósitos foram estabelecidos em A liberdade e é no contexto dessa obra que a expressão deve ser compreendida ${ }^{276}$.

Mas a tentativa de se compreender o sentido de tal expressão no ensaio de John Stuart Mill pode não ser tão fácil. A esse respeito, Ian Shapiro observou que, em diferentes momentos da obra $A$ liberdade, Stuart Mill ofereceu interpretações diversas e incoerentes do princípio do dano. Para Shapiro, a razão disso não é apenas a vagueza própria do termo "dano", mas, principalmente, a já mencionada dificuldade de Stuart Mill em harmonizar as visões iluministas da verdade e da liberdade ${ }^{277}$.

Quando, por exemplo, Mill defende a poligamia mórmon, mesmo convencido de que as mulheres são por ela prejudicadas ${ }^{278}$, ou quando protesta contra a legislação promulgada para proibir vícios ${ }^{279}$, ele o faz ao argumento de que, nesses casos, as escolhas são voluntárias, não havendo, por isso, qualquer dano. Nesses casos, diz Shapiro, Mill oferece uma leitura "intencionalista" do princípio do dano: uma leitura que privilegia as intenções das pessoas envolvidas no caso concreto e que, por isso, está mais carregada de seu apego à liberdade. Muitas vezes, porém, Stuart Mill manifesta uma interpretação "consequencialista" de seu princípio: uma interpretação carregada do cientificismo utilitarista e para a qual não as intenções das pessoas, mas somente o cálculo racional pode definir se algum dano foi causado. Como exemplo, Shapiro cita a afirmação de Mill, segundo a qual o comércio é um ofício social, cuja prática afeta os interesses da sociedade em geral, podendo, por isso, sofrer a intervenção da coletividade ${ }^{280}$. Pode-se supor que tal leitura ocorre, também, quando Mill afirma que não se deve permitir a um homem utilizar-se de uma ponte insegura ${ }^{281}$, ou quando ele insiste na proibição de se celebrar um "contrato de escravidão",282

Embora bastante discutível e exposta de uma maneira menos clara do que se poderia esperar, a "tese das duas leituras" defendida por Ian Shapiro é útil por mostrar que a insuficiência do critério milliano tem origem numa dificuldade mais profunda: o desconcerto que envolve as relações entre verdade e liberdade.

\footnotetext{
${ }^{276}$ Ibidem.

${ }^{277}$ SHAPIRO, Ian. Os fundamentos morais da política. Op. cit., pp. 79-89.

${ }^{278}$ MILL, John Stuart. A liberdade / Utilitarismo. Op. cit., p. 139-141.

${ }^{279}$ MILL, John Stuart. A liberdade / Utilitarismo. Op. cit., pp. 148-152.

${ }^{280}$ MILL, John Stuart. A liberdade / Utilitarismo. Op. cit., pp. 144-146.

${ }^{281}$ MILL, John Stuart. A liberdade / Utilitarismo. Op. cit., p. 147.

${ }^{282}$ MILL, John Stuart. A liberdade / Utilitarismo. Op. cit., pp. 155-156.
} 
Além disso - e não por acaso -, as duas leituras por ele mencionadas podem ser diferenciadas não apenas pelo fato de que a primeira privilegia as intenções e a segunda, as consequências, mas também pelo fato de que a primeira leitura parece atribuir mais consideração à vontade do indivíduo que a segunda. Vejamos.

Os críticos de Mill consideram-no incoerente, entre outras razões, porque ele defende a intervenção estatal no caso do sujeito que anda em uma ponte, mas insiste em combatê-la no caso das mulheres mórmons. A acusação de incoerência tem uma causa óbvia: sem oferecer argumentos que justifiquem tal diferença, Mill leva em consideração a vontade das mulheres mórmons, diante da poligamia, mas desconsidera completamente a vontade do andarilho sobre a ponte. É, pois, antipaternalista no primeiro caso e paternalista no segundo.

Em defesa de Stuart Mill, tem sido dito que apenas as ações totalmente voluntárias - e que digam respeito ao próprio agente - é que devem ser preservadas das intervenções da coletividade. Assim, impedir o sujeito de usar a ponte não consiste num ato paternalista, porque, nesse caso, a resolução de Stuart Mill leva em conta os fortes motivos existentes para se acreditar (ou afirmar) que a escolha do indivíduo não é voluntária $^{283}$.

Mas se as críticas feitas a Mill - incluindo as de Ian Shapiro quanto à aplicabilidade do famoso princípio -, remetem-nos, ainda uma vez, ao tema da vontade livre, o melhor a fazer é examinar o que Stuart Mill pensava a respeito.

\subsection{4 - Mais uma vez, a livre vontade}

Nos capítulos anteriores, tratamos do tema da vontade livre sem mencionar que John Stuart Mill, num texto quase contemporâneo à obra A Liberdade, igualmente havia se embrenhado nessa complexa reflexão sobre os conflitos a que se sujeitam os egos volitivos. Hannah Arendt também chamou a atenção para esse texto e para o fato de que Mill, bem à semelhança de Santo Agostinho, reconhecera em sua filosofia o problema da vontade constantemente dividida. Nesse texto, a propósito de criticar o pensamento de Sir

${ }^{283}$ ARNESON, Richard J.. "Mill versus Paternalism". In: Ethics. Volume 90, n 4: The University of Chicago Press, 1980, pp. 470-489 e FEINBERG, Joel. Filosofia social. Op. cit., pp. 76-79. 
Willian Hamilton, Stuart Mill enfatizou que o conflito vivido pelo ser livre não é travado entre este e alguma força a ele exterior, mas é um embate que se dá no próprio ego ${ }^{284}$.

No entanto, e talvez porque isso explicasse o fenômeno do arrependimento, parecia-lhe natural que o indivíduo se identificasse mais com alguma das partes em conflito:

O que faz com que eu, ou se quiser, minha Vontade, seja identificada com um [dos lados em conflito] e não com o outro, é o fato de que um dos 'eus' representa um estado mais permanente dos meus sentimentos do que o outro. Depois que a tentação vence, o 'eu' que deseja desaparece, mas o 'eu' arrependido pode durar pelo resto da vida" ${ }^{285}$.

Ademais, em sua reflexão sobre esse tema, o racionalismo de Mill teve um peso importante. Para Mill, o bom indivíduo é aquele cujo desejo de fazer o certo é forte o suficiente para sobrepujar o desejo contrário. E a educação moral, como não podia deixar de ser, tinha justamente o papel de educar a vontade ${ }^{286}$. A educação moral teria o papel de ensinar a vontade a seguir os bons desejos: exaltando os desejos que conduzem o indivíduo ao bem e enfraquecendo as inclinações mais suscetíveis de guiá-lo ao mal. À parte as perguntas mais notórias - Caberia ao educador definir quais são os bons desejos, ou estes são autoevidentes? -, o que se vê é o mesmo problema que Isaiah Berlin associou à liberdade positiva: a via de mão única para o despotismo. Não por acaso, ao analisar tais considerações, Hannah Arendt afirmou que, em Stuart Mill, a educação surge "como um deus ex machina". Segundo ela, "a proposição de Mill baseia-se em um pressuposto não

\footnotetext{
${ }^{284}$ MILL, John Stuart. "Chapter XXVI: On Freedom of the Will”. In: The collected works of John Stuart Mill, Volume IX - An examination of Willian Hamilton's philosophy. Londres: Routledge and Kegan Paul, 1979, pp. 14-15. Disponível em http://oll.libertyfund.org/?option=com_staticxt\&staticfile=show.php\%3Ftitle=240\&chapter=40902\&layout= html\&Itemid=27. Para uma análise dos escritos de Mill sobre esse tema, ARENDT, Hannah. $A$ vida do espírito: o pensar, o querer, o julgar. Traduzido por Antonio Abranches e Helena Franco Martins. 2. ed. Rio de Janeiro: Civilização Brasileira, 2010, p. 360.

${ }^{285}$ MILL, John Stuart. "Chapter XXVI: On Freedom of the Will”. Op. cit., pp. 14-15. Veja-se também ARENDT, Hannah. A vida do espírito... Op. cit., p. 360. (Tradução livre).

${ }^{286}$ Nas palavras de Mill: "The object of moral education is to educate the will: but the will can only be educated through the desires and aversions; by eradicating or weakening such of them as are likeliest to lead to evil; exalting to the highest pitch the desire of right conduct ad the aversion to wrong; cultivating all other desires and aversions of which the ordinary operation is auxiliary to right while discountenancing so immoderate an indulgence of them, as might render them too powerful to be overcome by moral sentiment, when they chance to be in opposition to it", em MILL, John Stuart. "Chapter XXVI: On Freedom of the Will'. Op. cit., p. 15.
} 
examinado - semelhante aos que os filósofos da moral adotam com uma confiança enorme, e que não podem ser provados ou refutados ${ }^{287}$,. Resta saber se, para Mill, a vontade forjada por um educador é, ainda assim, uma vontade livre.

\section{4 - A tradição democrática}

Ao tratarmos dos detratores do Iluminismo, antecipamos as razões pelas quais, para Ian Shapiro, a tradição democrática é a que melhor incorpora os valores do Iluminismo maduro e a que oferece melhores recursos para administrar as tensões que frequentemente surgem entre os dois grandes compromissos iluministas.

Segundo Shapiro, todas as vertentes da tradição democrática têm em comum aspectos que implicam o abandono das veleidades mais ambiciosas do Iluminismo e que estão associadas à versão primitiva do projeto iluminista: a ambição de substituir escolhas políticas pelas técnicas (ciência) e a ambição de tratar os direitos individuais como elementos prioritários em relação à política (liberdade). E, talvez por isso, as principais teorias de justificação do Estado influenciadas pelo Iluminismo primitivo dão pouca importância ao sistema democrático ${ }^{288}$.

No tocante à busca pela verdade, a democracia se sai melhor que as alternativas conhecidas, porque ela institucionaliza a disputa de ideias - processo, aliás, fundamental para o florescimento da verdade na teoria de Mill ${ }^{289}$. Assim, quando "sólidas organizações de oposição" enfrentam-se num contexto de proteção às liberdades de pensamento e de discussão, o método democrático acaba sendo a maior esperança de realização de um debate que tem a verdade como "ideal regulador" 290 . Sem falar que, em comparação com as outras doutrinas, a democracia representa o abandono do absolutismo filosófico e do dogmatismo racionalista, em favor do falibilismo que a aproxima do Iluminismo maduro ${ }^{291}$.

\footnotetext{
${ }^{287}$ ARENDT, Hannah. A vida do espírito... Op. cit., p. 361.

${ }^{288}$ SHAPIRO, Ian. Os fundamentos morais da política. Op. cit., p. 246.

${ }^{289}$ SHAPIRO, Ian. Os fundamentos morais da política. Op. cit., p. 260.

${ }^{290}$ SHAPIRO, Ian. Os fundamentos morais da política. Op. cit., p. 295.

${ }^{291}$ SHAPIRO, Ian. Os fundamentos morais da política. Op. cit., p. 296.
} 
No tocante à acusação de que a democracia enfraquece a liberdade individual, a tese de Shapiro apenas vem corroborar o entendimento já expresso por Bobbio: a história demonstra que "as liberdades políticas acabaram sendo consideravelmente mais respeitadas nas democracias" $" 292$. A história apresenta como bem sucedida a estratégia democrática de possibilitar que as liberdades individuais sejam construídas no âmbito da política.

\section{5 - A democracia em John Stuart Mill}

Os intelectuais têm mesmo razões para desconfiar da democracia.

Já há alguns anos, a democracia venezuelana tem recebido mais atenção da comunidade internacional, em razão das denúncias de que o governo venezuelano vem abusando do recurso à democracia direta para investir reiteradamente contra as liberdades individuais dos cidadãos. Trata-se de um exemplo atual das marcas que alimentam essa desconfiança $^{293}$.

No Brasil, tivemos outro exemplo desse mal-estar nas recentes eleições para a escolha dos membros do poder legislativo dos Estados federados e da União. O deputado federal que recebeu o maior número de votos foi justamente o candidato que mais ostensivamente zombou de toda a seriedade com que normalmente encaramos os processos democráticos. Em sua campanha, veiculada em rádio e televisão, ele dizia: "Sou candidato a Deputado Federal. O que é que faz um deputado federal? Na realidade eu não sei. Mas vote em mim que eu te conto" 294 .

Como vimos no início deste trabalho, as críticas ao princípio majoritário e, consequentemente, à democracia, são geralmente veiculadas em duas frentes. A primeira aponta seu caráter arbitrário e irracional: a regra da maioria não conduz o grupo às melhores decisões, pois ela não tem qualquer comprometimento pela busca racional da

\footnotetext{
${ }^{292}$ SHAPIRO, Ian. Os fundamentos morais da política. Op. cit., p. 282.

293“"Vargas Llosa: Com Chávez, Venezuela ruma à ditadura", in O Estado de São Paulo, disponível http://www.estadao.com.br/noticias/internacional,vargas-llosa-com-chavez-venezuela-ruma-aditadura,378637,0.htm.

${ }^{294}$ Frase veiculada no horário eleitoral gratuito durante a campanha de 2010.
} 
verdade e é arbitrária, porque insensível às preferências individuais. A segunda destaca sua propensão à tirania e sua hostilidade às liberdades individuais.

Diante dessas duas fontes de desconfiança ante o método democrático, não nos causaria surpresa alguma que John Stuart Mill houvesse desprezado a democracia em sua obra. Afinal, nada parecia mais racionalista que o utilitarismo por ele pregado; e nada era mais liberal que seus discursos sobre as liberdades individuais. Vimos, no entanto, que Stuart Mill era um verdadeiro democrata, tendo apresentado, em suas Considerações sobre Governo Representativo, uma das mais formidáveis defesas do governo popular representativo. Seria essa mais uma contradição da obra milliana?

\subsection{1 - O utilitarismo e a regra da maioria}

Buscar a maior felicidade para o maior número e atribuir igual valor a cada indivíduo são duas orientações essenciais da doutrina utilitarista. Não é difícil identificar uma conexão entre tais imperativos e dois dos mais básicos elementos de uma concepção procedimental de democracia - ascendência da maioria e o princípio do "um homem, um voto”. Essa conexão, porém, não é lógica e está longe de ser necessariamente verificada na prática. Para os autores utilitaristas, é bastante claro que o método democrático não produz necessariamente as mesmas decisões que seriam alcançadas pelo raciocínio moral utilitário $^{295}$. Apesar disso, é possível demonstrar que há razões morais utilitaristas para o respeito aos princípios democráticos e para a obediência às decisões majoritárias. É isso que o filósofo australiano Peter Singer busca demonstrar em sua obra Ética prática.

Em Ética prática, Singer aposta no utilitarismo como o melhor método para se discernir entre as condutas moralmente corretas e as incorretas. Bem por isso, ele entende que se deve rejeitar a ideia segundo a qual a maioria está sempre certa. Quando submetemos nossas questões morais à aprovação da maioria, estamos como que fazendo uma aposta: apostamos que a decisão moralmente mais acertada receberá o maior número de votos. Mas essa, diz Singer, "é uma aposta que com frequência vamos perder"296.

\footnotetext{
${ }^{295}$ Sobre essa conexão, remeto o leitor aos importantes apontamentos de Peter Singer e Fred Rosen. SINGER, Peter. Ética Prática. Op. cit., pp. 311-318; ROSEN, Fred. "Liberdade constitucional e democracia representativa". Traduzido por C. Cintra. In: PELUSO, Luis Alberto (org.). Ética e utilitarismo. Campinas: Editora Alínea, 1998, pp. 49-62.

${ }^{296}$ SINGER, Peter. Ética Prática. Op. cit., p. 316.
} 
Comparar eleições com apostas não é muito diferente da analogia com que iniciamos estes escritos: contar votos assemelha-se mais a um jogo do que a qualquer procedimento que possamos chamar racional. Exposto dessa maneira, o princípio majoritário está longe de parecer um imperativo moral.

No entanto, diz Singer, "não devemos desdenhar muito as eleições, nem as apostas", pois quem usa desses meios para resolver suas controvérsias age melhor do que aqueles que o fazem por meio da força ou recorrendo a $\operatorname{armas}^{297}$. A razão utilitária para nossa obediência ao governo democrático e às decisões majoritárias é, fundamentalmente, a mesma que sustenta o dever moral de obediência às leis e tem a ver com sua tendência a maximizar a felicidade para o maior número. Mas vale anotar que as características do regime democrático oferecem inúmeras razões adicionais para a observância das leis civis. Segundo Peter Singer, a ascendência da maioria, aliada ao sufrágio universal, constitui a melhor base possível para a resolução de controvérsias. Daí o grande peso moral que, sob a ótica utilitarista, deve ser atribuído ao princípio majoritário. Afirma Singer:

\begin{abstract}
Um método de resolver controvérsias no qual ninguém tem um poder maior do que os outros é um método que pode ser recomendado a todos como um excelente compromisso entre reivindicações antagônicas de poder. Qualquer outro método deve atribuir maior poder a alguns e menos a outros, sendo, portanto, um convite à oposição por parte dos que têm menos ${ }^{298}$.
\end{abstract}

No capítulo em que trata do dever geral de submissão às leis, Peter Singer procura mostrar que, na prática, o abandono do princípio majoritário não significará a ascendência dos mais sábios ou a prevalência de um governo mais liberal, mas tão somente a ascendência dos mais fortes. Daí nosso dever de lealdade para com o governo democrático que o raciocínio utilitarista necessariamente implica ${ }^{299}$.

É claro que, para os utilitaristas de um modo geral, o dever de observar os ditames democráticos não é absoluto, pois está, como todos os princípios próprios do raciocínio intuitivo, subordinado ao princípio da utilidade. Por isso mesmo, pode haver

\footnotetext{
${ }^{297}$ Ibidem.

${ }^{298}$ SINGER, Peter. Ética Prática. Op. Cit., p. 317.

${ }^{299}$ SINGER, Peter. Ética Prática. Op. Cit., p. 318.
} 
casos em que a análise em nível crítico indicará o desrespeito a leis democráticas como a solução moralmente mais correta. Mas, diante de tudo o que se afirmou, é evidentemente mais difícil para um utilitarista justificar a desobediência civil numa democracia, porque, no ambiente democrático, a existência de procedimentos legais previamente estabelecidos para a modificação de normas consideradas injustas torna injustificável o uso de meios ilícitos $^{300}$.

Embora sustente sua inclinação democrática numa linha não muito diferente dessa que acabamos de apresentar, John Stuart Mill acrescenta elementos que guardam pouca ou nenhuma relação com a doutrina utilitarista ${ }^{301}$. Para Mill, o governo popular tem dois aspectos valorosos. Em primeiro lugar, ele maximiza o bem-estar coletivo, porque o melhor guardião de seu interesse é o próprio interessado e, no governo popular, a coletividade tem o poder de proteger os interesses individuais e coletivos ${ }^{302}$. Em segundo lugar, o governo popular influencia positivamente a formação do caráter individual, pois ajuda a forjar indivíduos ativos, educados para se preocupar com a ponderação de interesses que não os próprios, e para aplicar princípios que digam respeito ao bem-estar geral. Esta última qualidade da democracia é, segundo Mill, a mais importante para se salientar sua superioridade. Por isso, José Guilherme Merquior chegou a afirmar que, enquanto seu pai - James Mill - prescreveu a democracia com o objetivo de minimizar a opressão sobre o povo, John Stuart prescreveu-a como forma de ampliar responsabilidade do povo ${ }^{303}$.

Em suas Considerações sobre o governo representativo, John Stuart Mill não apenas descreveu o governo popular como aquele que vem acompanhado do maior número de consequências benéficas ${ }^{304}$, mas também proclamou a ascendência da maioria numérica como "menos injusta e, em conjunto, menos perniciosa do que muitas outras"305.

\footnotetext{
${ }^{300}$ SINGER, Peter. Ética Prática. Op. cit., p. 314.

${ }^{301}$ MILL, John Stuart. Considerações sobre o governo representativo. Traduzido por Jacy Monteiro. São Paulo: Ibrasa, 1964, pp. 40-48.

302 Também para Bentham esse argumento pesava em favor da democracia. Sobre isso, José Guilherme Merquior afirmou: "A advocacia que Bentham fez pela democracia foi caracteristicamente animada por um espírito rijo. Ele não teve dificuldades em admitir que as maiorias podem estar completamente erradas. A longo prazo, no entanto, o consentimento geral é o sinal mais seguro de utilidade geral porque a maioria, tendo um interesse natural em sua maior felicidade, também tem interesse em descobrir e corrigir erros". MERQUIOR, José Guilherme. O liberalismo - antigo e moderno. Op. cit., p. 79. Veja-se também ROSEN, Fred. "Liberdade constitucional e democracia representativa". Op. cit., pp. 57-60.

${ }^{303}$ MERQUIOR, José Guilherme. O liberalismo - antigo e moderno. Op. cit., p. 97.

${ }^{304}$ MILL, John Stuart. Considerações sobre o governo representativo. Op. cit., p. 39.

${ }^{305}$ MILL, John Stuart. Considerações sobre o governo representativo. Op. cit., p. 100.
} 
E como entendesse impossível a participação de todos nas deliberações legislativas, Mill asseverou que a melhor forma de governo possível era a democracia representativa.

As qualidades que ele exaltava no método democrático, porém, não o impediram de identificar dois tipos de perigos a que, por suas próprias características, está sujeita a democracia. Cuida-se, nas suas palavras, do "perigo de grau inferior de inteligência no grupo representativo e na opinião pública que o controla" e do "perigo de legislação de classe por parte da maioria numérica, se esta se compuser toda ela da mesma classe $^{, 306}$. Para nosso autor, a questão era saber como organizar a democracia de modo a afastar essas duas enfermidades. À parte o fato de serem versões diferentes das duas principais preocupações historicamente associadas à regra da maioria - irracionalidade e despotismo majoritário -, é preciso dizer que Mill parecia recear mais a segunda espécie de perigo.

Com efeito, sabemos que John Stuart Mill temia o risco da legislação produzida em favor da classe dominante. Para ele, a maior dificuldade da democracia tem sido a busca por uma forma de garantir "apoio social, ponto de apoio para a resistência individual contra as tendências do poder que tem mando: proteção, ponto de arregimentação para opiniões e interesses que opinião pública ascendente encara com desfavor" ${ }^{307}$. No seu entender, a maioria numérica poderia tornar-se tirânica e, como exemplo dessa tendência, Mill citava a experiência norte-americana: "Nos Estados Unidos, onde a maioria numérica tem estado há muito na inteira posse do despotismo coletivo, esta se mostraria provavelmente tão pouco disposta a abrir mão dele como qualquer déspota único ou aristocracia",308.

No âmbito de suas Considerações sobre o governo representativo, Mill acreditou ter encontrado soluções para minimizar esses riscos. No tocante ao despotismo majoritário, propôs a organização de um governo representativo no qual as minorias fossem representadas e tivessem voz no parlamento (representação proporcional) ${ }^{309}$ solução que, como veremos, expõe a novas luzes o papel pretendido por Mill para o seu princípio do dano.

\footnotetext{
${ }^{306}$ MILL, John Stuart. Considerações sobre o governo representativo. Op. cit., p. 88.

${ }^{307}$ MILL, John Stuart. Considerações sobre o governo representativo. Op. cit., p. 100.

${ }^{308}$ MILL, John Stuart. Considerações sobre o governo representativo. Op. cit., p. 102.

${ }^{309}$ MILL, John Stuart. Considerações sobre o governo representativo. Op. cit., pp. 90-100.
} 
Quanto ao problema da decadência intelectual, Mill pensou que pudesse diminuir esse risco com sua conhecida - e infame - proposta para instituir um sistema de votação plural no qual os mais bem qualificados pudessem dar mais de um voto. O peso maior que se deveria atribuir ao voto dos mais instruídos fazia sentido para Mill, pois, no seu entender, não seria justo atribuir à opinião de um homem sábio o mesmo valor que se atribui à de um homem com inteligência inferior: "o julgamento do indivíduo de moral ou inteligência mais elevada vale mais" ${ }^{, 310}$. Nesse aspecto, é preciso reconhecer, ainda uma vez, o quanto a importância atribuída ao conhecimento e à razão influenciou sobremaneira as elaborações teóricas de Mill e o quanto essa influência colidia, por vezes, com seu apego à liberdade humana: ele negou peremptoriamente que se pudesse atribuir maior direito ao voto em razão do sexo, das características físicas do indivíduo, ou mesmo de sua condição econômica; mas abriu uma exceção aos mais instruídos - mesmo sabendo que o direito ao voto é elemento importante para a autodeterminação do indivíduo e que, para um utilitarista coerente, a felicidade de um néscio mereceria tanta consideração quanto à de um sábio. Para Mill, contudo, não se tratava de atribuir menos valor aos interesses dos menos instruídos. Tratava-se de assegurar que a inteligência política na Inglaterra não atingisse um "padrão demasiadamente baixo"311.

Ian Shapiro estava certo ao colocar Mill entre os autores cujas teorias não lograram administrar o conflito entre as duas demandas Iluministas. Um utilitarismo em que o princípio da utilidade cede lugar ao "princípio da liberdade", a concepção de vontade livre que se apoia na noção de "eu permanente" e a atribuição de maior peso ao voto dos mais instruídos são apenas exemplos das perplexidades geradas por esse conflito.

\section{6 - O princípio do dano e a regra da maioria ${ }^{312}$}

Em que sentido John Stuart Mill pretendia que seu princípio do dano fosse um limite à regra da maioria? Tê-lo-ia pensado como um limite institucional, tal qual

\footnotetext{
${ }^{310}$ MILL, John Stuart. Considerações sobre o governo representativo. Op. cit., p. 116.

${ }^{311}$ MILL, John Stuart. Considerações sobre o governo representativo. Op. cit., p. 115.

${ }^{312}$ Nesta seção, seguimos de perto algumas considerações de Jeremy Waldron a respeito do princípio do dano formulado por John Stuart Mill. Veja-se WALDRON, Jeremy. Derecho y desacuerdos. Traduzido ao espanhol por José Luis Marti e Águeda Quiroga. Madrid: Marcial Pons Ediciones Jurídicas y Sociales, 2005, pp. 365-372 e WALDRON, Jeremy. A Dignidade da Legislação. Traduzido por Luís Carlos Borges. São Paulo: Martins Fontes, 2003, pp. 100-101.
} 
aquele que as cláusulas pétreas constitucionais impõem às decisões majoritárias no parlamento? Para fechar este capítulo, convém fazer uma breve reflexão sobre tais questionamentos.

George Sabine - que, como vimos, não está entre os mais benevolentes intérpretes de Mill - entendia que uma das mais importantes e inovadoras contribuições de Stuart Mill para a ciência política era sua compreensão arguta e realista de como a liberdade deveria ser obtida. Para Mill, diz Sabine, estava claro que a conquista da liberdade não se resumia a um mero problema de organização política. "O que Mill compreendera e que nenhum dos antigos liberais percebera era que, por trás do governo liberal, deveria haver uma sociedade liberal" ${ }^{313}$. Em outras palavras: o contexto social determina o funcionamento das instituições políticas. De fato, quando Mill afirma que a individualidade não resistirá, "a menos que se faça a parte inteligente do público sentir seu valor"314; ou quando salienta a necessidade de se "levantar uma forte barreira de convicção moral" contra a "crescente inclinação a dilatar indevidamente os poderes da sociedade sobre o indivíduo" 315 , fica claro que a preocupação de Mill é a opinião pública, não os $\operatorname{arranjos~políticos~}^{316}$.

Em Derechos y desacuerdos, Jeremy Waldron já havia chamado a atenção para esse aspecto da teoria milliana. Segundo Waldron, ao elaborar seu famoso princípio, Mill não estava preocupado em institucionalizar um limite aos procedimentos majoritários na política; estava, no fundo, preocupado com a interferência da opinião majoritária na vida privada individual: para Mill, portanto, seu ensaio tinha a finalidade de instruir a opinião pública $^{317}$.

Isso, certamente, nos dá uma nova visão sobre o pensamento político de Mill. É evidente que ele acreditava na importância de seu princípio do dano. Tanto que se referiu a ele como um princípio capaz de "governar absolutamente as relações da sociedade com o indivíduo", sendo explícito ao afirmar que se tratava de um limite, tanto à coerção "sob a forma de penalidades legais", quanto à coerção moral da opinião pública ${ }^{318}$.

\footnotetext{
${ }^{313}$ SABINE, George Holland. História das ideias políticas - Vol. 2. Op. cit., p. 689.

${ }^{314}$ MILL, John Stuart. A liberdade / Utilitarismo. Op. cit., p. 113.

${ }^{315}$ MILL, John Stuart. A liberdade / Utilitarismo. Op. cit., p. 24.

${ }^{316}$ WALDRON, Jeremy. Derecho y desacuerdos. Op. cit., p. 369.

${ }^{317}$ WALDRON, Jeremy. Derecho y desacuerdos. Op. cit., pp. 369-372.

${ }^{318}$ MILL, John Stuart. A liberdade / Utilitarismo. Op. cit., p. 17.
} 
Entretanto, como bem alerta Waldron, não há nada em seu ensaio $A$ liberdade que nos permita concluir pela intenção de estabelecer o princípio do dano como um limite "oficial" às decisões do parlamento. Não por acaso, na obra em que trata da democracia representativa, em vez de defender a aplicação do princípio do dano como limite ao poder parlamentar, foi o sistema de representação proporcional que Mill pensou como remédio mais adequado ao despotismo majoritário que viesse a surgir no parlamento ${ }^{319}$.

De fato, não se deve esperar, na teoria milliana, uma resposta explícita a perguntas como "Quem deve decidir que leis são paternalistas?”, ou “Quem, na estrutura burocrática do Estado, estaria incumbido de definir que ações causam danos a terceiros?”. Mas isso não significa que Stuart Mill não desejasse ver seu princípio aplicado também nas instituições políticas. Pelo contrário. Parece razoável crer que era justamente esse o seu desejo. Entretanto, ele entendia que seria preciso, antes, difundir um espírito de liberdade na cultura política em geral, pois somente dessa maneira o povo e seus representantes estariam aptos a levar o princípio do dano a sério. Como afirma Waldron a respeito do pensamento milliano: "Se a liberdade individual nos importa, então a primeira coisa que deveríamos fazer não é reclamar uma carta de direitos para ser aplicada por um tribunal, mas desenvolver entre nós uma cultura da liberdade que faça com que aqueles que participarão das decisões sociais e políticas mais importantes apreciem e levem a sério essa ideia de liberdade" 320 .

Nem se deve criticar John Stuart Mill por seu insucesso em encontrar uma fórmula objetiva que permitisse a distinção cabal entre as intervenções legítimas e as ilegítimas. Pois, quando escreveu $A$ liberdade, sua intenção não era a de elaborar um princípio cujo significado fosse indisputável e estreme de dúvidas, mas um princípio que orientasse a discussão sobre a intervenção estatal. E, conquanto soubesse da importância do dano como critério para o julgamento das intervenções, Mill parecia compreender que se tratava de um critério para pautar as discussões públicas - e não um critério de tal modo incontroverso que tornasse desnecessário o debate público. E, para essa compreensão, foi decisivo o valor que Mill atribuía à espontaneidade individual, aos desacordos no seio da sociedade e à livre discussão.

\footnotetext{
319 Jeremy Waldron não se atenta para esse fato, mas trata-se de uma observação importante para se compreender por que as ideias de Stuart Mill não rejeitam, antes corroboram, o valor da regra majoritária nos governos democráticos.

${ }^{320}$ WALDRON, Jeremy. Derecho y desacuerdos. Op. cit., p. 370.
} 
Com efeito, Mill ficou famoso pela efusiva defesa que fez da liberdade de pensamento e de discussão. Chegou a dizer que seria necessário fabricar o dissenso sempre que não houvesse controvérsias que dinamizassem o debate público. Não apenas porque a verdade tem mais a ganhar com o livre debate, mas também porque Mill acreditava que uma ideia só é verdadeiramente levada a sério, quando "ela mesma é objeto de disputa e de um debate dinâmico"321.

Ora, é evidente que o tema das intervenções estatais não escapa a essa regra: para Mill, as dúvidas quanto à natureza danosa de uma ação ou quanto ao caráter paternalista de determinada norma jurídica devem ser expostas ao debate.

Por outro lado, na democracia representativa defendida por Mill - com um sistema de representação proporcional que dá voz às minorias -, o parlamento serve como espelho dos desacordos e das opiniões existentes na sociedade. É, portanto, o ambiente mais adequado para que o uso eficiente das ideias defendidas por ele, em A liberdade, no tocante à coerção estatal.

Assim, Mill realmente pretendia que seu princípio do dano fosse objeto de discussão também no parlamento e que fosse levado a sério pelos representantes do povo como critério para julgar a legitimidade de propostas legislativas. Para Mill, sempre que a aplicação desse princípio fosse alvo de controvérsias, tais controvérsias seriam resolvidas pelo próprio parlamento, do mesmo modo como são solucionadas quaisquer divergências surgidas naquele âmbito: pela regra da maioria.

Esse é, segundo Jeremy Waldron, o modo como John Stuart Mill pretendia que seu famoso princípio funcionasse na prática. Com tais considerações, Waldron procura mostrar que, na visão de John Stuart Mill, o princípio do dano não era um limite para o parlamento como, por exemplo, são as cláusulas pétreas - que subtraem ao legislador o poder de decidir sobre determinadas questões -, mas um princípio a ser levado em consideração sempre que o legislador tivesse de implementar restrições às liberdades individuais.

\footnotetext{
${ }^{321}$ Ibidem. No capítulo 2, de sua obra $A$ liberdade, John Stuart Mill tece uma série de argumentos para mostrar "a tendência fatal dos homens a desistir de pensar sobre algo quando não é mais duvidoso" e para explicar que o conflito entre a opinião verdadeira e seu oposto é "essencial para a apreensão clara e o profundo sentimento de sua verdade". Em MILL, John Stuart. A liberdade / Utilitarismo. Op. cit., p. 67 e p. 70.
} 
Com efeito, podemos avançar para além dos argumentos de Jeremy Waldron e dizer que alguns aspectos relevantes da teoria milliana - como a visão falibilista acerca do conhecimento humano e a consequente defesa da livre discussão - estão, de certo modo, ligados ao respeito que geralmente se tem pelos procedimentos majoritários e que, certamente, Mill também possuía.

As considerações apresentadas nesta seção poderiam muito bem encerrar o presente trabalho. Esta dissertação foi escrita com o objetivo de mostrar como o princípio do dano poderia ser um limite à regra da maioria vigente na democracia. Embora tendo percorrido um longo caminho - no curso do qual foi necessário discorrer sobre as dificuldades enfrentadas por Mill para conciliar democracia e liberalismo, liberdade e racionalismo -, chegamos a algumas ideias mais consistentes sobre as pretensões de Mill a respeito desse princípio.

Porém, ainda são devidas algumas palavras sobre a relação entre o princípio do dano e a regra da maioria.

Afirmou-se, algumas linhas acima, que as controvérsias existentes no parlamento sobre a aplicação prática do princípio milliano devem ser resolvidas com o recurso à regra da maioria. Tal afirmação parece beirar o cinismo. Afinal, por tudo o que se discorreu neste trabalho acerca dos limites impostos ao princípio majoritário, parece um contrassenso atribuir à maioria a prerrogativa de decidir quando ela própria deve ser limitada.

Mas essa afirmação não soaria tão estranha se pudéssemos demonstrar que o respeito à regra da maioria, na democracia, guarda íntima relação com algumas das ideias mais caras a John Stuart Mill.

O objetivo do próximo capítulo será mostrar essa conexão, enfatizando-se as razões pelas quais, ao longo da história, o princípio majoritário tem sido considerado um valioso procedimento para a tomada de decisões coletivas. 


\section{CAPÍTULO IV - A REGRA DA MAIORIA}

Há um fim da trama? Esse fim não pode ser ético, já que a ética é uma ilusão dos homens, não das inescrutáveis divindades.

(Jorge Luis Borges) $)^{322}$

\section{1 - Por que devemos lealdade ao princípio majoritário?}

Afinal de contas, o que justifica nossa obediência às leis estatuídas com base no princípio majoritário?

No capítulo anterior, examinamos uma resposta utilitarista para essa pergunta (item 3.1.5). E vimos que o argumento utilitarista em favor da regra majoritária apresenta-a como uma regra secundária, submissa aos critérios racionais do utilitarismo, não havendo um dever irrestrito de lealdade para com ela.

Será esse o melhor argumento em prol da regra da maioria? Sobre isso, há duas considerações importantes.

Em primeiro lugar, é preciso reconhecer que esse argumento tem pouca valia para justificar a importância do princípio majoritário, quando dirigido a alguém que discorda das premissas e do raciocínio utilitarista. Com efeito, a pretensão de oferecer respostas sobre o certo e o errado, no tocante ao agir humano, é uma característica comum das doutrinas éticas e o utilitarismo não foge à regra: pretende-se como uma teoria racional, apta a demonstrar como os indivíduos devem proceder a cada escolha ética que houverem de realizar. Por isso mesmo, o utilitarismo tem pouco a dizer àqueles que com ele não concordam - e, evidentemente, muitos não aderem às ideias utilitaristas, afinal, a

${ }^{322}$ BORGES, Jorge Luis. “1982”. In: Os conjurados. Traduzido por Pepe Escobar. São Paulo: Editora Três, 1985. 
pluralidade é a marca das sociedades modernas: alguns acreditam que a medida do certo e do errado está em alguma outra doutrina igualmente racional e abrangente; outros creem que está em algum texto sagrado; outros, que está em sua própria intuição etc. $\mathrm{O}$ utilitarismo pode, no máximo, reprovar-lhes a conduta ou tentar convencê-los e, exatamente por isso, não oferece resposta satisfatória quando o problema é tomar um curso de ação para toda a coletividade, respeitando a pluralidade de convicções e os vários desacordos existentes ${ }^{323}$.

Em segundo lugar, é preciso lembrar que o próprio John Stuart Mill, no âmbito do utilitarismo que professava, concedeu tão significativo valor à espontaneidade individual e à livre expressão que as fez prevalecer sobre o racional princípio da maior felicidade. E o fez, porque sua postura filosófica era pautada por uma visão falibilista do conhecimento humano. Nesse passo, cumpre levar a sério a sugestão com que fechamos o capítulo anterior: algumas das ideias mais caras a Stuart Mill - o grande valor da espontaneidade individual, a importância das controvérsias no seio da sociedade, a visão falibilista do conhecimento - têm relação direta com os motivos pelos quais a regra da maioria é digna do valor que as sociedades democráticas lhe conferem.

Assim, neste capítulo, o objetivo será examinar, uma vez mais, alguns argumentos em prol do princípio majoritário e discorrer, sucintamente, sobre como a existência de desacordos e a concepção falibilista do conhecimento dão ainda mais peso à importância desse princípio.

\section{2 - Argumentos axiológicos e técnicos: o estudo de Norberto Bobbio}

Segundo Norberto Bobbio, os argumentos tradicionalmente usados para oferecer uma justificação racional à regra da maioria podem ser classificados como axiológicos ou técnicos. Com base nos argumentos axiológicos, a regra justifica-se, porque permite, mais do que qualquer outra, "a satisfação de alguns valores fundamentais, como a

${ }^{323}$ É o que nos alerta Jeremy Waldron: "Há problemas também na suposição implícita de que o utilitarismo é a base subjacente adequada para o princípio da decisão. Não está nada claro que seja, especialmente quando estamos lidando com os elementos fundamentais do projeto social e constitucional. Nesse contexto, o princípio da utilidade é, pelo menos, tão controvertido quanto o princípio majoritário; interpretar esse em função daquele pode torná-lo mais inteligível, mas não torna a argumentação a favor da decisão majoritária mais persuasiva". WALDRON, Jeremy. A Dignidade da Legislação. Traduzido por Luís Carlos Borges. São Paulo: Martins Fontes, 2003, p. 177. 
liberdade e a igualdade" ${ }^{, 324}$. Com base nos argumentos técnicos, a regra é vista como um expediente técnico, muitas vezes necessário, para se alcançar a tomada de decisão coletiva entre pessoas com opiniões diversas ${ }^{325}$.

A classificação feita por Bobbio é extremamente didática e mostra que a tarefa central desses argumentos é sustentar a superioridade do princípio majoritário ante seus dois contrapontos: a unanimidade e a autocracia. Assim, quem defende a regra da maioria como alternativa à autocracia - a qual não respeita à vontade dos sujeitos nem os trata como iguais - geralmente apela aos valores da igualdade e da liberdade. Quem, por outro lado, reconhece a regra da maioria como um expediente útil, quiçá indispensável para a tomada de decisões de uma coletividade, normalmente defende-a como remédio para a difícil regra da unanimidade ${ }^{326}$.

Com sua exposição, Bobbio quer convencer o leitor de que os argumentos axiológicos são menos probantes se comparados aos técnicos ${ }^{327}$. A seguir, examinaremos mais de perto essa exposição de Bobbio.

\subsection{1 - Liberdade e Igualdade}

Os valores da igualdade e da liberdade são citados por muitos teóricos que defendem a regra da maioria como importante regra das democracias modernas. De fato, ao tratar do princípio majoritário, Kelsen afirmou que, na base da ideia democrática, está a síntese de liberdade e igualdade ${ }^{328}$. No entanto, a exposição de Bobbio nos mostra que o

\footnotetext{
324 BOBBIO, Norberto. Teoria geral da política: a filosofia e as lições dos clássicos. Organizado por Michelângelo Bovero; traduzido por Daniela Beccaccia Versiani. 2. ed. Rio de Janeiro: Ed. Campus, 2000, p. 432.

${ }^{325}$ BOBBIO, Norberto. Teoria geral da política... Op. cit., p. 432.

${ }^{326}$ BOBBIO, Norberto. Teoria geral da política... Op. cit., pp. 432-433.

${ }^{327}$ Elaine Spitz também apresenta uma exposição das justificativas normalmente oferecidas para se recorrer à regra da maioria. Segundo Spitz, há argumentos que apontam o princípio majoritário como intrinsecamente bom e que o descrevem como um procedimento apto a produzir as melhores decisões (as decisões mais justas ou mais sábias). É o caso, segundo ela, do argumento aristotélico em favor do governo dos muitos. Há também, segundo Spitz, argumentos que afirmam não o valor intrínseco do princípio majoritário, mas sua importância enquanto instrumento útil e, por vezes, necessário para a obtenção dos valores mais preciosos da humanidade - tal como o argumento de Thomas Jefferson, para quem os homens têm o direito natural ao autogoverno, cujo exercício apenas a regra da maioria está apta a promover. Por fim, há argumentos que justificam o princípio majoritário como um mal necessário. SPITZ, Elaine. Majority rule. Chatham: Chatham House Publishers, 1984, pp. 149-166.

${ }^{328}$ KELSEN, Hans. A democracia. Traduzido por Ivone Castilho Benedetti, Jefferson Luiz Camargo e Marcelo Brandão Cipolla. São Paulo: Martins Fontes, 2000, pp. 179-180. Sobre o princípio majoritário na
} 
erro de Kelsen começa ao reconhecer uma identidade entre o princípio majoritário e a ideia de democracia. Decerto que regimes democráticos utilizam-se da regra da maioria em muitas de suas decisões. Mas, na verdade, nem a regra da maioria é exclusiva dos regimes democráticos $^{329}$, nem os regimes democráticos tomam decisões coletivas, exclusivamente, pela regra da maioria. E boa parte da crítica de Bobbio aos argumentos axiológicos atém-se a essa constatação - a constatação de que democracia e princípio majoritário têm apenas uma parte de sua extensão em comum ${ }^{330}$.

Com efeito, é preciso dar razão a Bobbio quando ele afirma que a regra da maioria não guarda uma relação necessária com princípio da igualdade. $\mathrm{Na}$ assembleiageral de uma sociedade anônima, por exemplo, embora a tomada de decisões ocorra em observância ao princípio majoritário, cada acionista tem direito a um número de votos igual ao número de ações de que é titular ${ }^{331}$. Ninguém pensaria em dizer que, em casos como esse, a regra da maioria é um importante mecanismo para a efetividade do princípio igualitário.

Na realidade, diz Bobbio, a relação entre a regra da igualdade política e a regra da maioria apenas existe em regimes nos quais vigora o sufrágio universal. E, mesmo nesses casos, há sempre uma mitigação do princípio igualitário. Porque, onde há sufrágio universal, há sempre exceções ${ }^{332}$. Em suma: em sistemas que previamente acolheram o valor da igualdade entre as pessoas, a regra da maioria se impõe como procedimento para tomada de decisões. Em sistemas que não acolheram esse valor, a regra da maioria não fomentará maior igualdade. Conclui Bobbio: "a ideia de igualdade não pode ser assumida como razão justificadora do princípio da maioria",333.

teoria kelseniana, ver MARQUES, João Batista. "O princípio de maioria na doutrina de Hans Kelsen". In: Revista de Informação Legislativa, Brasília, vol. 42, n 165, janeiro/março 2005, pp. 51-58. Sobre a relação entre igualdade e liberdade, na democracia, ver MACHADO, Nilson José. "A maioria tem sempre razão. Ou não.". In: Revista USP, São Paulo, n 55, pp. 271-285, setembro/dezembro 2005. Nilson Machado faz a mesma menção sobre Kelsen, mas equivocadamente fala da Teoria Pura do Direito.

${ }^{329}$ Sobre isso, afirma Hannah Arendt que a regra da maioria "é um artifício técnico, suscetível de ser adotado quase automaticamente em todos os tipos de conselhos e assembleias deliberativas (...). Em outras palavras, o princípio da maioria está presente em todas as formas de governo, inclusive no despotismo, com a possível exceção, apenas, da tirania". ARENDT, Hannah. Da Revolução. Traduzido por Fernando Dídimo Vieira. Rio de Janeiro: Ed. UNB e Ática, 1988, p. 131.

${ }^{330}$ BOBBIO, Norberto. Teoria geral da política... Op. cit., pp. 428-429.

331 Veja-se o art. 110, da Lei no 6.404/76 - Lei das Sociedades Anônimas: "A cada ação ordinária corresponde 1 (um) voto nas deliberações da assembleia-geral".

${ }^{332}$ BOBBIO, Norberto. Teoria geral da política... Op. cit., pp. 433-434.

${ }^{333}$ BOBBIO, Norberto. Teoria geral da política... Op. cit., p. 434. 
O mesmo pode ser dito no tocante ao valor da liberdade individual. O clássico argumento usado por Hans Kelsen identifica a liberdade com a autodeterminação e considera que nenhuma forma de sociedade pode sobreviver se cada indivíduo orientar-se com uma autodeterminação sem limites. As liberdades individuais precisam, pois, ser limitadas. Para Kelsen, o princípio majoritário é aquele que permite tal limitação e, ao mesmo tempo, "assegura o mais alto grau possível de liberdade política em uma sociedade" 334 . Norberto Bobbio aponta falhas também nessa afirmação.

É que a liberdade política - entendida por Kelsen como a "conformidade entre a vontade individual e a vontade coletiva expressa na ordem social" - precisa ser fruto de uma livre determinação da vontade individual. E a regra da maioria, sendo um expediente técnico para a tomada de decisões coletivas, é sempre indiferente à formação da vontade subjacente aos votos computados. Se os votos a serem computados foram dados mais ou menos livremente, se foram dados por convicção ou por temor, nada disso importa para o princípio majoritário. Como vimos em 2.1.3, para Bobbio, a livre determinação da vontade depende de uma série de condições favoráveis previamente estabelecidas, como "reconhecimento e garantia dos direitos de liberdade, pluralidade de formações políticas, livre antagonismo entre elas, liberdade de propaganda, voto secreto etc."335. Tais condições precedem o exercício do direito ao voto e, consequentemente, a "entrada em funcionamento da regra da maioria, que é pura e simplesmente uma regra para o cálculo de votos" 336 . Por tudo isso, o fato de uma decisão coletiva ter sido tomada com base na regra da maioria nada diz acerca da maior ou menor liberdade com que tal decisão foi tomada. Portanto, atribuir à regra da maioria o poder de maximizar a liberdade "é atribuir-lhe uma virtude que não lhe pertence, ${ }^{337}$.

\section{3 - Expediente técnico}

A crítica de Bobbio ao uso de argumentos axiológicos é, de fato, tão precisa e contundente que somos tentados a descartá-los. Somos tentados a ver os argumentos

\footnotetext{
334 KELSEN, Hans. A democracia. Traduzido por Ivone Castilho Benedetti, Jefferson Luiz Camargo e Marcelo Brandão Cipolla. São Paulo: Martins Fontes, 2000, pp. 178-179.

${ }^{335}$ BOBBIO, Norberto. Teoria geral da política... Op. cit., p. 436.

${ }^{336}$ Ibidem.

${ }^{337}$ Ibidem.
} 
técnicos como os únicos que podem, racionalmente, justificar a tomada de decisões pela regra da maioria. No entanto, nem o próprio Norberto Bobbio seguiu esse caminho. Segundo ele, é justo reconhecermos que a consideração do princípio majoritário como expediente técnico quase não vale quando ele é comparado à autocracia ${ }^{338}$. De sua exposição é possível concluir que, acolhidos os valores democráticos e assumido o compromisso de protegê-los, a regra da maioria surge como um expediente necessário e valioso.

Por isso, é preciso tomar cuidado ao se referir a tal regra como mero expediente técnico. Jogar dados é um recurso técnico eficaz e, em meio às divergências dos seres humanos, é tão hábil a propiciar tomadas rápidas de decisão, quanto é a contagem de votos. Mas deve-se questionar se o jogo de dados presta aos valores democráticos o mesmo serviço prestado pelo procedimento majoritário. E a resposta é a que o leitor já suspeitava: não.

\section{4 - Jeremy Waldron: A dignidade do princípio majoritário}

De dois modos Jeremy Waldron procurou defender a regra da maioria como um procedimento que merece nossa lealdade e nosso respeito. De um lado, buscou refutar a acusação de arbitrariedade que pesa sobre a legislação criada de acordo com tal regra. De outro, buscou demonstrar que o propalado receio ante a "tirania da maioria" somente teve lugar na história da filosofia política, porque os jusfilósofos não consideraram adequadamente - e, de certo modo, até desprezaram - o papel das discordâncias em suas teorias.

Waldron tornou-se um autor polêmico quando, em vários de seus textos, desferiu críticas persuasivas ao constitucionalismo contemporâneo e a uma de suas principais marcas: a revisão judicial da constitucionalidade das leis. Por trás dessas críticas, estava a compreensão de que, numa democracia, as decisões majoritárias devem prevalecer, em virtude, principalmente, do modo respeitoso com que tratam a questão das discordâncias. Os argumentos de Waldron sobre esse tema foram compilados em duas importantes obras: Derecho e desacuerdos e A dignidade da legislação.

\footnotetext{
${ }^{338}$ BOBBIO, Norberto. Teoria geral da política... Op. cit., p. 438.
} 
Para que se possa compreender a defesa que Jeremy Waldron faz da regra da maioria, é preciso, antes, examinar os objetivos em busca dos quais ele escreveu esses dois trabalhos. Em ambos, o desiderato parece ser o mesmo: convencer o leitor de que a legislação produzida segundo o princípio majoritário é digna de nossa lealdade, porque é a melhor resposta que se pode dar ao irrefragável fato dos desacordos.

Segundo Waldron, a filosofia do direito tem dado pouca importância à questão dos desacordos. O desacordo em relação à justiça e aos direitos é uma característica persistente da política contemporânea e suas consequências teóricas não deveriam ser desprezadas.

"Somos muitos e discordamos sobre justiça" „339. Essa afirmação é o ponto a partir do qual Waldron desenvolve seu projeto intelectual. A existência de desacordos e a necessidade, sentida por todos, de um curso de ação comum são o que ele chamou de "circunstâncias da política",340. São essas circunstâncias que tornam indispensável o estabelecimento de uma autoridade política.

\subsection{1 - A física do consentimento}

Será a regra majoritária um mero expediente técnico?

Para tentar responder a essa questão, a partir de um ponto de vista diverso do proposto até agora, convém examinarmos o argumento usado por John Locke no Segundo Tratado:

Pois quando um número qualquer de homens formou, pelo consentimento de cada indivíduo, uma comunidade, fizeram eles de tal comunidade, dessa forma, um corpo único, com poder de agir como um corpo único, o que se dá apenas pela vontade e determinação da maioria. Pois sendo aquilo que leva qualquer comunidade a agir apenas o consentimento de seus indivíduos, e sendo necessário àquilo que é um corpo mover-se numa certa direção, é necessário que esse corpo se mova na direção determinada pela força predominante, que é o consentimento da maioria; do contrário, torna-se impossível que aja ou se mantenha como um corpo único, uma comunidade única, tal como concordaram devesse ser os

\footnotetext{
339 WALDRON, Jeremy. Derecho y desacuerdos. Traduzido ao espanhol por José Luis Marti e Águeda Quiroga. Madrid: Marcial Pons Ediciones Jurídicas y Sociales, 2005, p. 07 (tradução livre).

${ }^{340}$ WALDRON, Jeremy. Derecho y desacuerdos. Op. cit., pp. 123-124.
} 
indivíduos que nela se uniram - de modo que todos são obrigados por esse consentimento a decidir pela maioria ${ }^{341}$.

No argumento de Locke, a decisão majoritária é justificada por meio de uma analogia com a física. Já de início, porém, percebemos que a analogia não é perfeita. Em primeiro lugar, no argumento lockeano, o resultado do embate político não é - tal como se esperaria de um raciocínio fundado nas leis da física - a "soma vetorial" das vontades (algo como uma solução intermediária, conciliatória), mas a proposta que obtém o maior número de consentimentos. Em segundo lugar, com essa analogia, Locke parece querer apresentar o princípio majoritário como um dado natural: o corpo social move-se naturalmente na direção da maioria, assim como o corpo sólido naturalmente se movimenta na direção do vetor resultante. Todavia, uma abordagem puramente naturalista não explica algo que parece pressuposto em seu argumento - o fato de que o corpo social continuará unido. Pois a coesão das partículas não é um dado natural, comum a todos os corpos, e não pode, bem por isso, ser explicada como algo natural num argumento baseado na força física. Por isso, diz Waldron, não se deve interpretar esse trecho como um argumento fisicalista: a física que Locke tem em mente é a "física do consentimento" 342.

O consentimento individual, diz Waldron, é um dado da maior importância na doutrina de John Locke: para ele, somente o consentimento de seus indivíduos leva uma comunidade a agir. Por isso, a exigência do consentimento não está presente apenas nas situações em que o corpo social tem de agir, mas está presente, sobretudo, numa fase anterior - a fase em que se celebra o contrato social -, na qual os membros firmam o compromisso de permanecerem unidos a despeito dos desacordos. Ou seja, a base para a coesão política surge nessa etapa, com o consentimento original dado por todos os membros: "O consentimento original, então, é consentimento para ser obrigado por um ou outro processo decisório, um processo decisório que pode muito bem envolver algo menos que a unanimidade" 343 .

Por isso, segundo Jeremy Waldron, esse argumento assenta-se em três pressupostos que, de certo modo, fundamentam a visão de Locke sobre o princípio

\footnotetext{
${ }^{341}$ LOCKE, John. Dois Tratados sobre o Governo. Traduzido por Julio Fischer; rev. técnica de Renato Janine Ribeiro. São Paulo: Martins Fontes, 2005, p. 469.

${ }^{342}$ WALDRON, Jeremy. A Dignidade da Legislação. Op. cit., p. 166.

${ }^{343}$ WALDRON, Jeremy. A Dignidade da Legislação. Op. cit., p. 170.
} 
majoritário. O primeiro é o do consentimento original. $\mathrm{O}$ fato de a sociedade seguir os rumos escolhidos pela maioria pressupõe um compromisso inicial de todos os membros, no sentido de que permanecerão vivendo em sociedade, a despeito dos profundos desacordos que venham a surgir. Trata-se de um compromisso não acerca do tipo de processo decisório que regerá as ações do corpo, mas de um compromisso apenas sobre a coesão: os membros comprometem-se a permanecer unidos, por mais díspares e intensas que sejam as vontades individuais e independentemente do processo decisório escolhido ${ }^{344}$.

O segundo pressuposto, já salientado, é o de que o corpo social tomará sempre um dos rumos previamente propostos e não um caminho conciliatório. Segundo Waldron, esse pressuposto indica que Locke rejeita, para a vida em sociedade, a necessidade de decisões unânimes ou consensuais. O terceiro pressuposto é o de que os consentimentos individuais expressos pelos indivíduos têm igual valor para o resultado final. Isso, porque o que está sendo contado é o consentimento dado ou negado em relação a cada proposta anunciada, e não o grau de entusiasmo individual despertado pelas propostas. Locke não supõe que as vontades individuais externadas sejam de igual intensidade. Apenas entende que, nas questões para as quais importa o consentimento, a intensidade deste é irrelevante. Para a celebração de um contrato, por exemplo, o que importa é a concordância das partes e não o entusiasmo com que concordam. Assim, no argumento de Locke em favor da regra majoritária, o consentimento não pode ser visto como uma força que imprime movimento ao corpo social ${ }^{345}$; deve, antes, ser compreendido como uma força legitimadora, autorizadora ${ }^{346}$.

Por outro lado, segundo Waldron, a "lógica ampla do consentimento na exposição de Locke tem relação com a justiça para os indivíduos e com o reconhecimento

\footnotetext{
${ }^{344}$ WALDRON, Jeremy. A Dignidade da Legislação. Op. cit., pp. 168-172.

345 Segundo Waldron, a conclusão do argumento lockeano "não depende de nenhuma analogia direta com a agregação de forças físicas”. WALDRON, Jeremy. A Dignidade da Legislação. Op. cit., p. 178.

${ }^{346} \mathrm{O}$ cientista político Claus Offe também deu ênfase à legitimidade como importante argumento em prol do princípio majoritário. Segundo ele, a regra da maioria é boa, porque torna a decisão legítima, isto é, "merecedora de aceitação". OFFE, Claus. "Legitimação política por decisão majoritária?". In: Problemas estruturais do Estado capitalista. Traduzido por Barbara Fraitag. Rio de Janeiro: Ed. Tempo Brasileiro, 1984, p. 319. Segundo Lucio Levi, o termo legitimidade tem dois significados na linguagem comum. No sentido genérico, legitimidade aproxima-se das noções de justiça ou racionalidade. Em seu sentido específico, próprio da linguagem política, legitimidade é "um atributo do Estado, que consiste na presença, em uma parcela significativa da população, de um grau de consenso capaz de assegurar a obediência sem a necessidade de recorrer ao uso da força, a não ser em casos esporádicos." LEVI, Lucio. "Legitimidade". In: BOBBIO, Norberto; MATTEUCCI, Nicola; PASQUINO, Gianfranco. Dicionário de política - Vol. 2. Traduzido por Carmen C. Varriale et. al. 12. ed. Brasília: UNB, 2004, p. 675.
} 
e o respeito pela sua posição como iguais" ${ }^{347}$. Assim, além de expor a importância da legitimidade para as ações políticas, o argumento de Locke sugere, também, a importância da equidade e a visão de que o princípio majoritário é a resposta mais evidente ao problema de se proceder equitativamente nas circunstâncias em que membros do corpo têm opiniões diferentes sobre como o corpo deve agir.

Diante disso, o argumento de Locke pode ser interpretado do seguinte modo. Quando firmam o contrato para formar a sociedade, os membros concordam em permanecer unidos, porque, por diversas razões, acreditam que devem agir e tomar decisões conjuntamente. Além disso, se a lógica do consentimento dita o tom desse compromisso, então os membros necessariamente concordam que, para o fim de legitimar as decisões, o consentimento de cada um é igualmente importante. Por fim, os membros estão de acordo quanto ao último ponto: para tomar decisões, eles não contarão com nada além das opiniões pessoais de cada um. Nessas circunstâncias, o princípio majoritário torna-se o método decisório mais equitativo. De um lado, ele torna "minimamente decisiva" a opinião de cada indivíduo, pois quando o aplicamos a qualquer tomada de decisões, verificamos que, "se o membro $\mathrm{M}_{1}$ pensa que devemos fazer $\mathrm{X}$ e nenhum outro membro do grupo tem uma opinião, então X é o que devemos fazer" ${ }^{348}$. De outro, ele dá a cada indivíduo um poder decisivo máximo, apenas limitado pela exigência de igualdade entre eles $^{349}$.

Mas o que o argumento de John Locke e sua adequada interpretação, dada por Waldron, podem acrescentar ao que se viu até agora acerca do princípio majoritário?

Em suma, a exposição lockeana nos mostra que há mais em favor da regra da maioria do que o mero fato de ser um expediente técnico prático e eficaz. Da condição inicial do grupo nascem, conforme vimos, as exigências de legitimidade e equidade. A importância do princípio majoritário está ligada ao serviço que ele presta a essas duas exigências, por respeitar os indivíduos, tratando-os "como iguais na autorização da ação política"350.

\footnotetext{
${ }^{347}$ WALDRON, Jeremy. A Dignidade da Legislação. Op. cit., pp. 178-179.

${ }^{348}$ WALDRON, Jeremy. A Dignidade da Legislação. Op. cit., p. 180.

${ }^{349}$ Ibidem.

${ }^{350}$ WALDRON, Jeremy. A Dignidade da Legislação. Op. cit., p. 183 e p. 194.
} 
No mais, para Jeremy Waldron, as suposições presentes no argumento de Locke denotam a compreensão de que a coesão social e a pluralidade de opiniões são marcas permanentes da vida em sociedade. Por isso, essas suposições exemplificam bem aquilo que Waldron chamou "circunstâncias da política".

\title{
4.4.1.1 - As circunstâncias da política
}

A existência de divergências profundas entre os membros da sociedade e a necessidade que eles têm de agir coletivamente é o que Jeremy Waldron chamou circunstâncias da política. Esse conceito tem papel central no desenvolvimento de suas ideias. Sobre ele, Waldron escreveu:

\begin{abstract}
Eis uma analogia. Considerem a ideia das circunstâncias da justiça de John Rawls - os aspectos factuais da condição humana, como a escassez moderada de recursos e o altruísmo limitado dos indivíduos, que tornam a justiça como virtude e prática possível e necessária. Podemos dizer, nessa mesma linha, que a discordância entre os cidadãos quanto ao que devem fazer, como corpo político, é uma das circunstâncias da política. Não é totalmente circunstâncias da política, é claro: há também a necessidade sentida de agir conjuntamente, embora discordemos quanto ao que fazer. Como a escassez e o altruísmo limitado no caso da justiça, as circunstâncias da política são um par conjugado: a discordância não teria importância se as pessoas não preferissem uma decisão comum, e a necessidade de uma decisão comum não daria origem à política como a conhecemos se não houvesse pelo menos o potencial para a discordância quanto a qual deve ser a decisão comum ${ }^{351}$.
\end{abstract}

Nesse relevante ponto da teoria de Waldron, é possível notar a influência ${ }^{352}$ de alguns ilustres pensadores, a começar pela explícita referência a John Rawls que, em Uma teoria da justiça, descreveu as circunstâncias da justiça como uma realidade a partir da qual deveriam ser pensadas as questões relativas à justiça - e que, sagazmente, ressaltou a permanente discordância dos homens quanto aos princípios básicos de sua associação ${ }^{353}$. Sem falar na influência de Hobbes - que descreveu a condição do homem como "uma

\footnotetext{
${ }^{351}$ WALDRON, Jeremy. A Dignidade da Legislação. Op. cit., p. 187.

352 Sobre essas influências, veja-se GARGARELLA, Roberto e MARTÍ, José Luis. "Estudio preliminar". In: WALDRON, Jeremy. Derecho y desacuerdos. Op. cit., p. XVIII.

${ }^{353}$ WALDRON, Jeremy. Derecho y desacuerdos. Op. cit., p. 184 e RAWLS, John. Uma teoria da justiça. Traduzido por Almiro Pisetta e Lenita M. R. Esteves. São Paulo: Martins Fontes, 1997, p. 05 e pp. 136-140.
} 
condição de guerra de todos contra todos"354, extraindo dela uma série de consequências sobre a vida em sociedade, as quais expôs nos capítulos XIV e XV de seu Leviatã -; na influência de Herbert Hart, com sua exposição sobre o "conteúdo mínimo do Direito Natural"355; e na influência de Hannah Arendt, para quem a condição humana da pluralidade é a conditio sine qua non da esfera pública ${ }^{356}$.

Sobre Hannah Arendt, aliás, Waldron observa que ela desenvolveu uma das melhores teorias sobre a vocação humana pela política. Segundo Waldron, a conveniência do agir coletivo e a importância da ação concertada são temas que percorrem a filosofia política dessa autora ${ }^{357}$. Seguindo a lição de Hannah Arendt, Waldron nos mostra que a ação concertada é algo extremamente útil, embora muito difícil de engendrar. Por isso, quando ocorre, representa uma verdadeira conquista para os homens ${ }^{358}$.

Em seus escritos, Waldron não busca demonstrar a existência das circunstâncias da política; ele simplesmente as supõe como condições elementares da política moderna. Mas, uma vez aceita tal suposição - e não é difícil aceitá-la, dada sua plausibilidade - nossa visão sobre o papel das instituições políticas altera-se: para Waldron, os filósofos da política e do direito erram ao desprezar as consequências teóricas dessas condições.

Veja-se o fato dos desacordos. Considerá-lo como uma marca permanente da vida em sociedade implica aceitar que o consenso não é o resultado necessário das deliberações políticas. Essa ideia vale uma digressão.

Twelve Angry Men é um clássico do cinema e um dos mais famosos filmes sobre casos submetidos ao Tribunal do Júri ${ }^{359}$. O enredo é simples. Doze jurados estão

\footnotetext{
${ }^{354}$ HOBBES, Thomas. Leviatã ou Matéria, forma e poder de um estado eclesiástico e civil. Organizado por Richard Tuck; traduzido por João Paulo Monteiro e Maria Beatriz Nizza da Silva; tradução revisada por Eunice Ostrensky. São Paulo: Martins Fontes, 2008 (Clássicos Cambridge de filosofia política), p. 112.

${ }^{355}$ HART, Herbert L. A.. O conceito de direito. Traduzido por Antonio de Oliveira Sette-Câmara; pós-escrito e organizado por Penelope A. Bulloch e Joseph Raz. São Paulo: Editora WMF Martins Fontes, 2009, pp. 250-258.

${ }^{356}$ ARENDT, Hannah. A condição humana. Traduzido por Roberto Raposo. 10. ed. Rio de Janeiro: Forense Universitária, 2009, p. 233.

${ }^{357}$ WALDRON, Jeremy. Derecho y desacuerdos. Op. cit., pp. 93-94 e WALDRON, Jeremy. A Dignidade da Legislação. Op. cit., p. 190. Veja-se também LAFER, Celso. Hannah Arendt: pensamento, persuasão e poder. 2. ed. São Paulo: Paz e Terra, 1988, p. 98.

358 WALDRON, Jeremy. A Dignidade da Legislação. Op. cit., p.190. ARENDT, Hannah. A condição humana. Op. cit., p. 192 e pp. 194-211.

${ }^{359}$ Filme de 1957, dirigido por Sidney Lumet, produzido e protagonizado por Henry Fonda e veiculado no Brasil com o título Doze homens e uma sentença.
} 
incumbidos de julgar um rapaz acusado de parricídio. Onze deles entram na sala secreta convencidos de que o réu é culpado, enquanto apenas um manifesta dúvida sobre como decidir. Este último, porém, munido apenas de bons argumentos, acaba, após uma demorada discussão, convencendo os demais de que há, no caso, uma dúvida razoável que torna imperativa a absolvição. Trata-se de uma história que enfatiza a importância da deliberação para a obtenção da verdade; ao seu final, a justiça da decisão surge como que evidente.

Aceitar o desacordo como uma das circunstâncias da política, contudo, é aceitar que, na deliberação política, as coisas não se passam desse modo: na política, o consenso é a exceção e o desacordo, a regra. Se o desacordo é uma característica persistente da vida em sociedade, então é natural que ele persista mesmo após uma longa e conscienciosa deliberação. Vivemos ao lado de muitas outras pessoas e não há a menor perspectiva de compartilharmos com elas uma visão comum sobre direitos e justiça ${ }^{360}$.

Diante das circunstâncias da política, diz Waldron, é preciso buscar procedimentos que se mostrem respeitosos em relação aos desacordos e que permitam a participação de todos na escolha dos rumos coletivos a serem tomados ${ }^{361}$.

\subsection{2 - Método respeitável}

A regra da maioria respeita os indivíduos de duas maneiras.

Em primeiro lugar, ela respeita a pluralidade de opiniões individuais existentes no seio da sociedade, porque não exige o consenso como resultado das discussões e reflexões políticas. De fato, quando se tem o consenso como resultado natural de uma deliberação racional, a demora em obtê-lo logo dá margem à suspeita de que alguns membros, por alguma razão, não têm capacidade de enxergar a verdade, ou estão movidos por interesses particulares. A tentação imediata, nesses casos, é a de desconsiderar as opiniões de quem resiste em concordar com os que já chegaram a um consenso. A decisão majoritária, ao contrário, não exige que os indivíduos renunciem às próprias convicções em nome do consenso. Se um único cidadão qualquer pensa que a

\footnotetext{
${ }^{360}$ WALDRON, Jeremy. A Dignidade da Legislação. Op. cit., pp. 185-187.

${ }^{361}$ WALDRON, Jeremy. Derecho y desacuerdos. Op. cit., p. 105.
} 
opção "X" é o melhor para a sociedade, mas todos os outros pensam que o melhor é a opção "Y”, o princípio majoritário jamais exigirá que o sujeito solitário mude de opinião. O princípio do consenso também não exige, é verdade. Mas, de outro giro, não permite a tomada de rumo algum até que o sujeito ceda (ou até que cedam os demais). Já a regra da maioria requer o contrário: que renunciemos a nossa pretensão de consenso. Por isso, ela respeita as divergências ${ }^{362}$.

É evidente que há outros procedimentos igualmente respeitosos em relação aos desacordos. Um procedimento que se valha do acaso - como jogar dados, tirar cara ou coroa etc. -, ou qualquer método consistente na eleição de um líder para escolher pelo grupo são técnicas decisórias que não exigem o consenso. No entanto, quando se lança um dado com vistas a decidir um rumo para a sociedade, as opiniões dos seus membros não são de modo algum contadas - não importa se $99 \%$ dos membros preferem a opção " $X$ ”. E quando um líder escolhe pelo grupo, apenas a opinião dele é considerada, também não importando o que pensam os demais.

Exatamente nesse aspecto, reside a segunda maneira pela qual o princípio majoritário respeita os indivíduos. Como observa Jeremy Waldron, para a regra da maioria,

o fato de que certo indivíduo respalda a opção $X$ é uma razão para que o grupo adote a opção $\mathrm{X}$, ainda quando existam desacordos. Precisamente porque existem tais desacordos, não se trata de uma razão concludente, mas ainda assim, conta a favor de que o grupo adote $\mathrm{X}^{363}$.

Ou seja, a opção pelo princípio majoritário é a opção por um método que dá ao consentimento individual um peso autorizador; cada opinião é levada em conta. E ele o faz de um modo ainda mais respeitoso, pois atribui peso igual a cada um dos consentimentos manifestados ${ }^{364}$.

A defesa lockeana do princípio majoritário já apontava para o aspecto da igualdade. O princípio dá poder decisivo máximo a cada cidadão, limitado apenas pela exigência de igualdade. A exigência de igualdade, porém, mostra-se rígida demais. Nas

\footnotetext{
${ }^{362}$ WALDRON, Jeremy. Derecho y desacuerdos. Op. cit., pp. 133-134.

${ }^{363}$ WALDRON, Jeremy. Derecho y desacuerdos. Op. cit., p. 137 (tradução livre).

${ }^{364}$ WALDRON, Jeremy. Derecho y desacuerdos. Op. cit., p. 136-137.
} 
circunstâncias da política moderna, a grandiosidade dos números - a mesma condição que torna necessário o governo representativo - dá a cada membro a sensação de que pouco influi nas decisões coletivas. Assim, o fato de milhões de pessoas decidirem juntas faz parecer ao indivíduo que seu voto possui um peso mínimo. No entanto, como tivemos oportunidade de observar, o compromisso com a regra da maioria é uma opção por atribuir peso igual às preferências de cada indivíduo, seguindo o princípio de que aquilo que afeta a todos, deve ser decidido por todos ${ }^{365}$. Se uma questão é tal que afeta a milhões de pessoas, então qualquer intenção de se atribuir um peso maior à vontade de um indivíduo só poderia lograr êxito "ao custo de se reduzir ainda mais o peso atribuído aos pontos de vista dos demais" 366 .

É nesse sentido, portanto, que a decisão majoritária presta bons serviços ao valor da igualdade. Norberto Bobbio acertou ao descrever uma conexão entre o princípio da maioria e a ideia de igualdade, mas errou ao concluir que a igualdade não é uma "razão justificadora" daquele princípio. Segundo Bobbio, "a conexão existe no sentido de que, uma vez acolhida essa ideia, o princípio da maioria se impõe; não no sentido oposto, de que o princípio da maioria implique a ideia de igualdade ${ }^{„ 367}$. Ora, se a regra da maioria impõe-se logo que é acolhido o valor da igualdade, é porque, de algum modo, ela se apresenta como um meio necessário para a proteção ou fortalecimento desse valor. Portanto, a exigência de se proteger ou fortalecer o valor da igualdade é, sim, uma razão que justifica o recurso ao princípio majoritário.

Por outro lado, ainda no que diz respeito a essa questão, cabe a dúvida sobre se o valor da igualdade requer, de fato, a atribuição de igual peso à vontade de cada indivíduo. No capítulo anterior, vimos que John Stuart Mill não concordava com essa ideia. De acordo com Mill, o imperativo da igualdade não requer que a opinião de alguém sábio e instruído tenha o mesmo valor - e, por conseguinte, seja tão potencialmente decisiva - quanto à de uma pessoa ignorante. Assim, o princípio da igualdade material tradicionalmente identificado com a exigência de se tratar igualmente os iguais e desigualmente os desiguais - pode conter uma concepção de igual respeito que justifique alguma forma de votação plural, baseada nas diferenças quanto à instrução e à sabedoria dos cidadãos. Vimos que Stuart Mill compreendia dessa maneira a participação dos

\footnotetext{
${ }^{365}$ WALDRON, Jeremy. Derecho y desacuerdos. Op. cit., pp. 137-138.

${ }^{366}$ WALDRON, Jeremy. Derecho y desacuerdos. Op. cit., p. 138 (tradução livre).

${ }^{367}$ BOBBIO, Norberto. Teoria geral da política... Op. cit., p. 434.
} 
cidadãos. Entretanto, observamos que o sistema de votação plural, sugerido por Mill, está longe de ser coerente com suas premissas utilitaristas, uma vez que não há razão para se prestar menor consideração aos interesses dos menos instruídos ou menos inteligentes.

Seja como for, é bastante plausível a objeção de que a regra da maioria não outorga aos indivíduos o exato respeito a que têm direito. Pois, de fato, a regra da maioria desconsidera os aspectos que tornam diferentes os indivíduos e exige sempre um conceito de igualdade estritamente formal e, por isso, bastante empobrecido. O argumento é realmente persuasivo, mas apenas enquanto não se leva em conta o fato de que o respeito devido a cada indivíduo é, também - como tudo o que envolve justiça e de direitos -, objeto de desacordo. Por isso, um procedimento que respeita as diferenças substantivas entre os indivíduos é um procedimento que, necessariamente, privilegia um ponto de vista polêmico, isto é, um ponto de vista que não está acima dos desacordos. No entanto, como ensina Jeremy Waldron, é precisamente "porque discordamos quanto ao que deve ser considerado como o resultado substantivamente respeitoso que precisamos de um processo decisório",368. Em outras palavras, nas circunstâncias da política, a única noção de igual respeito com que se pode trabalhar é essa noção formal, restrita e necessariamente empobrecida, que dá a cada indivíduo igual poder decisivo ${ }^{369}$.

\subsubsection{1 - A arbitrariedade}

Já vimos que a decisão majoritária não pode ser considerada arbitrária no mesmo sentido em que normalmente se reconhecem como arbitrárias as decisões autocráticas e aquelas tomadas ao acaso. Nestes dois tipos de decisão, a razão para se decidir não é nada além do mero capricho do líder ou da sorte. Nesses casos, o termo "arbitrário" parece significar algo próximo a "irracional", sendo usado para se referir a uma decisão que não é fruto da reflexão pautada por argumentos, mas que é, antes, resultado do capricho ou do preconceito de quem decide, ou fruto de um evento aleatório e imponderável. Mas a regra da maioria diferencia-se daqueles dois outros procedimentos decisórios, precisamente, porque, mediante ela, a vontade de cada indivíduo conta sempre

\footnotetext{
${ }^{368}$ WALDRON, Jeremy. A Dignidade da Legislação. Op. cit., p. 197.

${ }^{369}$ WALDRON, Jeremy. Derecho y desacuerdos. Op. cit., pp. 138-140.
} 
como uma razão a mais para se tomar este ou aquele rumo. Não há, pois, que se falar em arbitrariedade nesse sentido ${ }^{370}$.

Agora, se por irracional ou arbitrário entendemos a falta de comprometimento com a busca pela verdade, devemos então recordar o que se disse sobre o modo pelo qual a democracia favorece essa busca (item 3.4). Se a democracia representa o abandono do absolutismo filosófico e do dogmatismo racionalista, isso se deve ao genuíno procedimento que dá igual e decisiva importância à opinião que cada cidadão tem sobre a verdade. E isso faz da democracia um regime mais favorável à busca do conhecimento pela livre troca de ideias. É claro que a regra da maioria não basta para o fortalecimento dessa busca. Há, na democracia, outros elementos - como, por exemplo, as regras de filiação e concorrência partidárias - que contribuem para institucionalizar a disputa de ideias, e isso, sim, é determinante para tornar a democracia mais receptiva às pretensões iluministas quanto à busca pela verdade. No entanto, quando usamos o princípio majoritário nas questões políticas, está implícito, nesse uso, o reconhecimento da falibilidade humana. E é essa visão falibilista do conhecimento que torna o pluralismo de ideias algo tão relevante para o florescimento da verdade ${ }^{371}$.

Na verdade, a aparência de arbitrariedade é o preço pago pelo respeito que o princípio majoritário presta à ação concertada e ao pluralismo.

Vimos que o pluralismo está intimamente ligado ao reconhecimento de que a razão humana é falível (item 2.2.4). E, diante da falibilidade humana, o melhor que se pode ter da verdade são as opiniões individuais e divergentes a seu respeito. Por isso, aceitar o desacordo moral como uma condição elementar da política não implica admitir o relativismo moral $^{372}$. A suposição do desacordo moral permanente nada diz sobre a existência da verdade ou sobre a existência de respostas certas para nossas questões mais inquietantes. No entanto, ao tratarmos do respeito às divergências (4.4.2), vimos que, no fato dos desacordos persistentes, está subentendida uma afirmação preciosa: por mais evidente e insofismável que nos pareça a verdade de uma ideia, nenhum indivíduo será obrigado a aceitá-la, não importa o quanto essa resistência nos pareça absurda ou irracional. Esse é o tipo de respeito que a regra da maioria incorpora. Nele, está implícito,

\footnotetext{
${ }^{370}$ WALDRON, Jeremy. Derecho y desacuerdos. Op. cit., pp. 136-137.

${ }^{371}$ SHAPIRO, Ian. Os fundamentos morais da politica. Traduzido por Fernando Santos. São Paulo: Martins Fontes, 2006, pp. 294-296.

${ }^{372}$ WALDRON, Jeremy. Derecho y desacuerdos. Op. cit., pp. 221-222.
} 
tal como sugerimos em 1.5.3, o reconhecimento da falibilidade humana. A regra da maioria não implica que a ética seja - como na frase de Borges - uma ilusão dos homens. Tampouco pressupõe que seja algo inescrutável, inalcançável para os pobres mortais. Apenas sugere que, não sendo possível aos indivíduos demonstrar inelutavelmente a verdade de qualquer de suas ideias, o que nos sobra da verdade são, quando muito, visões pessoais e falíveis dela.

Para Jeremy Waldron, parte do alarde que se faz a propósito de limitar a aplicação do princípio majoritário tem como causa a suspeita de sua arbitrariedade e irracionalidade. Como vimos, porém, tal suspeita não tem razão de ser. Se a persistente divergência em matéria de justiça e direito é uma das condições elementares da política, então irracional é o método decisório que ignora essa condição. E, se tudo o que temos acerca da verdade são opiniões distintas sobre o que é a verdade, então arbitrário é o método que acolhe uma dessas opiniões em detrimento das demais.

Antes, a contagem de cabeças se revelava como algo oposto ao tipo de cuidado que devemos ter para com a justiça e a verdade. Agora, porém, que estamos cientes do seu papel ante as circunstâncias da política, a regra da maioria surge diante de nós como um procedimento digno de nossa lealdade. Um procedimento apto a legitimar as decisões dele nascidas, porque comprometido com o ideal de igual consideração e respeito.

\subsubsection{2 - A "tirania da maioria"}

Resta ainda a acusação de que o princípio majoritário não protege adequadamente os direitos das minorias. Como vimos no início deste estudo, o temor por vezes manifestado ao longo da história é o de que a maioria formada nas reuniões deliberativas pudesse, por meio das decisões majoritárias, oprimir as minorias e desrespeitar os direitos individuais.

O conflito entre a autonomia individual e a regra da maioria - ao qual o título deste trabalho faz alusão - é sentido toda vez que um indivíduo, a contragosto, submete-se à vontade da maioria. Afinal, sujeitar-se à vontade alheia equivale a não ter autogoverno. A exposição feita no presente capítulo sugere, todavia, que essa situação desconfortável é o tributo que cada um paga pela conquista da ação consertada. Como nos 
ensina Hannah Arendt, "nenhum homem pode ser soberano, porque a Terra não é habitada por um homem, mas pelos homens"

No entanto, como vimos em 1.5.3, é comum sustentar-se a existência de situações nas quais a decisão majoritária, por razões de justiça, não deve prevalecer. Se admitimos a existência dessas situações, o passo seguinte é reconhecermos que, nesses casos, o indivíduo tem o direito de não se sujeitar à vontade majoritária e que a violação desse direito é um fato que extrapola a mera "situação desconfortável" - é um preço que a sociedade não deve estar disposta a pagar. O princípio do dano de John Stuart Mill é um exemplo marcante de como os teóricos buscam identificar tais situações. E os casos de aparente paternalismo estatal, aqui descritos, são exemplos persuasivos de violações ao direito de não se submeter à decisão majoritária: são exemplos de como a maioria pode tornar-se "tirana" 374 . Contudo, os limites que devem ser impostos ao princípio majoritário são também objeto de discórdia. Como lidar com esse problema?

Para Jeremy Waldron, palavras de ordem como "tirania da maioria" apenas contribuem para obscurecer o debate. Segundo ele, o temor ante o despotismo majoritário está fundado em duas premissas equivocadas ${ }^{375}$.

Em primeiro lugar, está fundado na suposição de que, na política, os indivíduos votam com base em seus interesses particulares. Entretanto, se a persistência dos desacordos é da essência da política, então é natural que os indivíduos discordem sobre um tema, mesmo após terem refletido longamente sobre ele, com imparcialidade e isenção. De modo que tal suposição não se sustenta: nem sempre os votos são dados por interesse. A persistência da discórdia não significa necessariamente má-fé e nem traduz uma atitude interesseira por parte dos indivíduos. Como ensina Jeremy Waldron, a suspeita de má-fé existe mais como um efeito previsível da busca indômita pelo consenso: se o consenso for o resultado necessário de uma deliberação racional, apenas a motivação interesseira poderá explicar porque as deliberações políticas nem sempre o alcançam. Para Waldron, o temor

\footnotetext{
${ }^{373}$ ARENDT, Hannah. A condição humana. Op. cit., p. 246. Não por acaso - para se retomar a discussão sobre os dois conceitos de liberdade mantida no capítulo 2 -, em sua obra, Hannah Arendt parece dar extrema ênfase à liberdade entendida como autonomia. Sobre isso, veja-se LAFER, Celso. Hannah Arendt: pensamento, persuasão e poder. Op. cit., pp. 97-98.

${ }^{374}$ Refiro-me aos exemplos do capítulo 1 (item 1.3): A obrigatoriedade do regime de separação de bens aos maiores de setenta anos e a obrigatoriedade de submeter-se à transfusão de sangue, nos casos em que há risco de morte.

${ }^{375}$ WALDRON, Jeremy. Derecho y desacuerdos. Op. cit., pp. 221-222.
} 
de que a maioria possa tiranizar as minorias, com seu comportamento interesseiro, tem sentido apenas quando se ignoram as circunstâncias da política.

Em segundo lugar, quando se diz que a maioria oprime a minoria, ou que a decisão majoritária viola direitos individuais, o que se supõe por trás dessas afirmações é a existência de direitos autoevidentes, não sujeitos a controvérsias. Direitos revestidos de um caráter sublime que os coloca acima dos desacordos. O problema, segundo Jeremy Waldron, é justamente esse: não há nada sobre direito e justiça que não possa ser objeto de controvérsia. Há, com efeito, desacordos sobre tudo: "sobre a existência de Deus", sobre o "sentido da vida", mas também sobre "os termos justos de cooperação entre as pessoas que não estão de acordo sobre a existência de Deus e o sentido da vida",376. Os temas e exemplos examinados neste estudo não fogem à regra. Há discórdia e muitas dúvidas sobre o que deve ser considerado paternalismo injusto, sobre quais ações lesam a terceiros, sobre os limites do princípio majoritário, sobre o direito de se dispor da própria vida etc. Há, enfim, um enorme desacordo sobre aquilo que torna uma lei justa e aquilo a torna tirânica.

À vista dessa realidade, o uso de expressões como "tirania da maioria", "minorias oprimidas" e "violação de direitos fundamentais" propicia a enganosa impressão de que é simples dizer quando e quais direitos das minorias são violados; e de que é fácil discernir entre direitos naturalmente fundamentais e direitos artificialmente produzidos. Assim, quem usa tais expressões fala como se fossem evidentes os direitos que devem prevalecer à decisão majoritária. No entanto, a controvérsia sobre direitos é, como exaustivamente se constatou, justamente, o contratempo que nos faz recorrer ao princípio majoritário.

Por isso, quando, a pretexto de se protegerem direitos individuais, um problema de justiça é excluído do crivo majoritário, isso apenas significa que uma visão particular acerca do problema já foi previamente escolhida, em detrimento de todas as outras visões. Anunciar previamente quais direitos devem triunfar sobre a decisão majoritária é "fazer uma petição de princípio sobre a questão mesma em jogo"377. Do mesmo modo, quando a opinião de um indivíduo está em desacordo com aquela respaldada pela maioria, é compreensível que ele critique a decisão. É compreensível que diga: "Não

\footnotetext{
${ }^{376}$ WALDRON, Jeremy. Derecho y desacuerdos. Op. cit., p. 07 (tradução livre).

377 MENDES, Conrado Hübner. Controle de Constitucionalidade e Democracia. Rio de Janeiro: Elsevier, 2008, p. 108.
} 
consideraram adequadamente todos os interesses!", ou "Não compreenderam corretamente o que é melhor para o bem-estar geral!”. Mas, ainda que o diga com fundamento em argumentos racionais, o mero fato de o dizer não implica, em si mesmo, que esse indivíduo tenha sido desrespeitado ou tiranizado pela maioria ${ }^{378}$.

Sobre isso, há uma passagem deveras emblemática em Leviatã, a partir da qual é possível sentir, uma vez mais, a influência de Hobbes sobre o pensamento de Jeremy Waldron. A certa altura, Hobbes afirma:

Quando os homens que se julgam mais sábios do que todos os outros clamam e exigem a razão como juiz, apenas procuram que as coisas sejam determinadas, não pela razão de outros homens, mas pela sua própria, e isso é tão intolerável na sociedade dos homens como é no jogo, uma vez escolhido o trunfo, usar como trunfo em todas as ocasiões aquela série de que se tem mais cartas na mão ${ }^{379}$.

\section{5 - O pluralismo de Mill}

Em toda nossa reflexão sobre as imprecisões do conceito de paternalismo, sobre os limites da regra majoritária e, especialmente, sobre as dificuldades do princípio do dano de John Stuart Mill, um mesmo problema nos fustigou durante todo o tempo: a dificuldade de se distinguir entre intervenções estatais justas e intervenções estatais injustas. A persistência dessa dificuldade, porém, é precisamente o que torna necessária a instituição de procedimentos decisórios - mas procedimentos decisórios cuja autoridade não dependa da qualidade das decisões ${ }^{380}$. É o que parece sugerir a tese de Jeremy Waldron. Para ele, a filosofia política tem duas tarefas básicas. A primeira é a de teorizar sobre justiça. Essa tarefa tem sido historicamente desempenhada por doutrinas éticas, como o utilitarismo e o contratualismo, e busca, entre outras coisas, oferecer alguma resposta àquela dificuldade. A segunda tarefa é a de "teorizar sobre o modo como atuam as comunidades quando existem desacordos entre seus membros" ${ }^{\prime 381}$.

\footnotetext{
${ }^{378}$ WALDRON, Jeremy. Derecho y desacuerdos. Op. cit., pp. 20-21.

${ }^{379}$ HOBBES, Thomas. Leviatã. Op. cit., p. 40.

${ }^{380}$ Essa é uma das mais importantes contribuições de Thomas Hobbes para a filosofia política. Segundo Conrado Hübner Mendes, a obra hobbesiana nos mostra que "qualquer teoria que faz a autoridade depender da qualidade das decisões políticas seria inadequada, pois, precisamente porque as pessoas discordam, precisamos estabelecer uma autoridade. Em MENDES, Conrado Hübner. Controle de Constitucionalidade e Democracia. Op. cit., p. 108.

${ }^{381}$ WALDRON, Jeremy. Derecho y desacuerdos. Op. cit., p. 10.
} 
No tocante a essa segunda tarefa, a exposição de Waldron nos revelou a existência de fortes razões para se considerar o princípio majoritário como o único processo decisório digno de nossa lealdade. Como vimos, longe de ser - em virtude de sua irracionalidade e de sua hostilidade contra as liberdades individuais - o atributo menos nobre dos regimes democráticos, o princípio majoritário é, na verdade, a marca que faz da democracia a única forma de governo que respeita os indivíduos da maneira aqui descrita. Respeita-os por favorecer o pluralismo de ideias e por reconhecê-los como iguais, atribuindo a cada um o poder decisivo máximo quanto às questões de justiça e de direito.

A defesa que Waldron faz do princípio majoritário não está isenta de críticas. Algumas são até bastante óbvias. De um lado, ele é criticado pela identificação simplista que faz entre a instituição do parlamento e o povo que ela representa. De fato, nada garante que seus argumentos permaneceriam tão persuasivos se ele tivesse empreendido uma reflexão mais profunda sobre a democracia representativa ${ }^{382}$. Depois, Waldron parece basear aquela defesa "na suposição de que as pessoas frequentemente votam a partir de opiniões imparciais" ${ }^{383}$. De fato, essa suposição muitas vezes se mostra verdadeira e é razoável acreditar que as teorias políticas devam almejar discussões políticas exclusivamente direcionadas ao bem comum $^{384}$. Mas, como a suposição nem sempre é verdadeira, o temor ante o despotismo majoritário não parece ser tão infundado quanto Waldron busca demonstrar. Por fim, não se pode esquecer a profusão de críticas formuladas por Ronald Dworkin, insistindo que a regra da maioria não é o único método que atende ao valor da igualdade, nas várias formas em que esse valor se manifesta ${ }^{385}$. Sem embargo, tais críticas não maculam as contribuições de Jeremy Waldron para os propósitos do presente trabalho. O próprio Waldron admite não poder provar, em definitivo, essa qualidade do princípio majoritário, nem mesmo quanto à concepção mais restrita de

\footnotetext{
382 GARGARELlA, Roberto e MARTÍ, José Luis. "Estudio preliminar". Op. cit., p. XXXVII. Waldron admite essa deficiência em uma "nota para os críticos". WALDRON, Jeremy. Derecho y desacuerdos. Op.cit., 133, n. 60.

${ }^{383}$ MENDES, Conrado Hübner. Controle de Constitucionalidade e Democracia. Op. cit., p. 85.

${ }^{384}$ Ibidem.

${ }^{385}$ DWORKIN, Ronald. "The Moral Reading and the Majoritarian Premise". In: KOH, Harold H. e SLYE, Ronald C. (organizadores). Deliberative democracy and human rights. New Haven e Londres: Yale University Press, 1999, pp. 81-115. Nesse artigo, Dworkin defende o que chamou de "constitutional conception of democracy". Essa concepção nega que a premissa majoritária seja o objetivo definidor da democracia. Segundo Dworkin, a democracia requer "que as decisões coletivas sejam tomadas por instituições cuja estrutura, composição e práticas tratem a todos os membros da comunidade, enquanto indivíduos, com igual consideração e respeito", p. 96 (tradução livre).
} 
igualdade ${ }^{386}$. Mas o conjunto de argumentos por ele trazido é suficiente para os propósitos dessa dissertação, no introito da qual, vale lembrar, renunciamos de antemão a qualquer pretensão de oferecer respostas cabais para o tema da justificação moral do princípio majoritário.

No final, os argumentos de Waldron em prol do princípio majoritário têm grande importância em nosso estudo, porque reforçam a conclusão formulada no final do capítulo 3 , segundo a qual o respeito devido às decisões majoritárias é consequência de duas ideias relevantes na teoria de John Stuart Mill: o falibilismo da razão humana e o decorrente valor do pluralismo.

Sobre isso, há uma última observação que deve ser feita.

Alan Ryan, um competente estudioso do liberalismo milliano, fez uma interessante comparação entre o pluralismo presente na obra de Stuart Mill e o pluralismo presente na obra de Isaiah Berlin. Segundo Alan Ryan, muito embora haja formas de pluralismo sobre as quais Mill e Berlin não estão de acordo, existe um tipo de pluralismo em torno do qual ambos concordam. É um pluralismo que se expressa na seguinte ideia: nós, humanos, não temos uma resposta definitiva e incontestável sobre aquilo em que consiste uma boa vida e, diante disso, é importante que conheçamos todas as diversas possibilidades de resposta, filtrando e refinando aquelas que nos pareçam melhores ${ }^{387}$.

Entre as razões que justificam o recurso à regra da maioria, a falibilidade do conhecimento humano ostenta papel diferenciado. A falibilidade é um dado da vida humana que explica por que a discórdia permanente é uma condição elementar da política. Além disso, a visão falibilista do conhecimento humano é, como vimos em 3.2, o atributo mais característico daquilo que se convencionou chamar Iluminismo maduro: é a principal marca da evolução por que passou o Iluminismo e que possibilitou um melhor convívio entre liberdade e verdade racional.

\footnotetext{
${ }^{386}$ WALDRON, Jeremy. Derecho y desacuerdos. Op. cit., p. 140.

387 RYAN, Alan. "Mill in a liberal landscape". In: SKORUPSKI, John (organizador). The Cambridge companion to Mill. Nova York: Cambridge University Press, 1998, pp. 531-536. Desse trecho é possível identificar a diferença entre o pluralismo de Stuart Mill e o de Isaiah Berlin. Embora reconheça a falibilidade humana e a possibilidade de jamais se obter a verdade em matéria de justiça, Mill confia na existência de repostas certas sobre o modo como as pessoas devem viver e entende que somente a razão e o livre debate podem alcançá-las. Ao contrário de Mill, Berlin é um pluralista moral. Logo, não se trata apenas de serem inalcançáveis as respostas sobre como devemos viver. Para Berlin, os diversos valores perseguidos pela humanidade são incompatíveis e, por isso, não há resposta certa: cabe ao homem escolher, em cada caso, que valor deve sacrificar.
} 
Nestes escritos, descrevemos mais de uma vez como o racionalismo dos filósofos sempre representou uma ameaça às aspirações verdadeiramente liberais. $\mathrm{O}$ reconhecimento da falibilidade humana, também quanto a esse fato, tem papel relevante. Como nos ensinou Isaiah Berlin, a falibilidade humana - um dos pilares de sua postura pluralista - é um fato que ilumina, como nenhum outro, a relevância permanente da liberdade de escolha (item 2.2.4). Não por outro motivo, o pluralismo é uma marca presente em várias correntes do pensamento liberal. Assim, se Bobbio explicou as afinidades entre democracia e liberalismo, ressaltando sua origem comum no individualismo (item 2.1.4), a falibilidade humana e sua relação com o valor da liberdade e com o fundamento do princípio majoritário reforçam, um pouco mais, a ideia de complementaridade entre os ideais liberais e a doutrina democrática.

Por fim, essas últimas palavras sobre a falibilidade da razão humana explicam, ainda, algo sobre a epígrafe que abriu o primeiro capítulo destes escritos. Nela o princípio majoritário é um preceito dirigido aos homens. Por ele, reconhecem-se, a um só tempo, a razão falível que o Criador concedeu aos sábios e a necessidade de se seguir um caminho comum para a observância harmoniosa de Seus inescrutáveis desígnios. 


\section{CAPÍTULO V - CONSIDERAÇÕES FINAIS}

Este trabalho buscou examinar as relações entre a regra da maioria e a liberdade individual, tendo como ponto de partida o pensamento do filósofo inglês John Stuart Mill. Duas sinceras inquietações estimularam o desenvolvimento da pesquisa empreendida. A primeira era a dúvida sobre o fundamento moral no qual se sustenta o hábito, amplamente difundido ao longo da história, de obediência às decisões majoritárias. A segunda consistia na dúvida sobre como o princípio defendido por John Stuart Mill poderia atuar como um limite à aplicação justa do princípio majoritário numa democracia. Desde o princípio, ambas as inquietações pareceram-nos obviamente ligadas: para se compreender por que, em algumas situações, o uso do princípio majoritário é inadequado, devemos, antes, entender por que, de um modo geral, seu uso é importante.

Quanto à primeira inquietação, notou-se que não havia nos autores clássicos da jusfilosofia a preocupação de dar um tratamento abrangente ao tema. E, dos autores tradicionalmente estudados na graduação da Faculdade de Direito da USP, apenas Norberto Bobbio cuidou de oferecer uma explicação mais cuidadosa e, de certo modo, mais sistemática, sobre o tema da regra da maioria e de seu fundamento. Por isso, foi necessário um longo caminho para se chegar a Jeremy Waldron, filósofo do direito neozelandês que, além de oferecer um dos estudos mais recentes sobre o tema, foi o que, a nosso ver, apresentou o trabalho mais profundo e convincente sobre o valor do método majoritário.

A segunda inquietação nasceu das múltiplas e controvertidas interpretações dadas ao princípio do dano de John Stuart Mill, apresentado por ele como um critério idôneo para estabelecer os limites da justa interferência da sociedade sobre a liberdade individual. Observou-se desde o início que, sobre o acerto e a funcionalidade desse princípio, recaíam inúmeras críticas que o denunciavam como critério inapto a indicar, na prática, o que seria uma intervenção estatal justa. Por outro lado, nas primeiras páginas do ensaio A liberdade, já ficava claro que o princípio do dano visava à defesa da liberdade, tanto em face do abuso majoritário, quanto em face do paternalismo estatal. Não por outra razão, o problema do paternalismo logo se tornou uma questão igualmente inquietante, à vista, especialmente, de sua considerável repercussão atual no Brasil, mostrando-se um 
adequado fio condutor para o andamento da presente pesquisa e uma conveniente forma de delimitar suas pretensões.

Já no início destes escritos, renunciamos à pretensão de buscar uma resposta definitiva para o problema da justificação moral do princípio majoritário, resignando-nos apenas ao objetivo de compreender como o princípio do dano poderia servir de critério, numa democracia, para a imposição de limites ao princípio majoritário.

Diante de tal propósito, as conclusões mais importantes deste trabalho são as seguintes:

1) A melhor forma de interpretar o princípio do dano, no âmbito dos procedimentos democráticos, é reconhecê-lo como um critério que deve pautar as discussões legislativas; um critério que deve ser seriamente considerado pelo legislador, sempre que ele tiver de estabelecer restrições às liberdades individuais. Nessa linha, no final do capítulo 3, damos razão a Jeremy Waldron quando ele afirma que a intenção de Stuart Mill era, simplesmente, a de instruir a opinião pública. Ou seja, pelas razões explicadas naquele capítulo, Mill não pretendia que seu princípio atuasse como um limite, digamos, institucional ao parlamento. Não deveria ser, portanto, um critério que retirasse do legislador o poder de decidir sobre as questões de justiça e de direito.

2) Algumas das ideias mais relevantes no pensamento de John Stuart Mill em especial, sua percepção falibilista da razão humana - ajudam a compreender e até reforçam a importância dos procedimentos majoritários na democracia - procedimentos pelos quais Stuart Mill, certamente, nutria respeito.

Ao fim e ao cabo, entendemos que esta dissertação acaba oferecendo duas pequenas contribuições ao vastíssimo repertório da jusfilosofia contemporânea. Primeiramente, ela apresenta uma defesa liberal do princípio majoritário: mais especificamente, uma defesa baseada no liberalismo de John Stuart Mill. Em segundo lugar, oferece uma exposição percuciente - ainda que horizontalmente restrita, porque pautada na visão de alguns poucos autores - das dificuldades enfrentadas por Stuart Mill para desenvolver uma teoria liberal compatível com sua visão racionalista do conhecimento moral e com sua inclinação pelo governo democrático. Façamos, pois, um breve apanhado do quanto se expôs ao longo presente estudo e das principais conclusões alcançadas. 
Num primeiro momento, apresentamos algumas premissas importantes para a compreensão deste trabalho. Expusemos as críticas dirigidas à teoria milliana; apresentamos as críticas dirigidas à regra da maioria como método decisório, e o consequente apelo à imposição de limites para sua aplicação; mencionamos a associação imediata entre a decisão majoritária e o relativismo moral; e descrevemos as dificuldades que envolvem o conceito de paternalismo e algumas teorias a seu respeito.

Em seguida, no segundo capítulo, desenvolveu-se uma reflexão sobre as relações entre liberalismo e democracia. Iniciada com um breve relato sobre evolução do conceito de liberdade, essa reflexão teve por base a distinção entre as noções de liberdade moderna (liberal) e liberdade antiga (democrática). Já nesse relato inicial, tomou-se o cuidado de apontar o difícil convívio entre liberdade e necessidade, em torno do qual orbitaram as discussões medievais sobre o problema da vontade livre.

Depois de uma longa apresentação dos pensamentos de Norberto Bobbio e Isaiah Berlin acerca das relações entre os dois conceitos de liberdade, concluiu-se que, para Bobbio, dada a complementaridade daquelas duas noções de liberdade, a democracia se apresenta como a evolução natural do Estado liberal. Para Bobbio, a explicação é simples: liberalismo e democracia têm uma origem comum na concepção individualista da sociedade. Já para Berlin, essa afinidade entre democracia e liberalismo não é necessária e, muitas vezes, a democracia representa um perigo para os ideais liberais.

Uma das mais importantes contribuições de Berlin para este estudo é sua descrição de como a liberdade antiga - que ele chamou positiva - foi muitas vezes identificada com a procura de fins racionais, o que, segundo ele, não demorou a implicar práticas autoritárias. Ao encerrar a metáfora do autodomínio, a liberdade positiva acaba pondo em xeque a convicção liberal de que a vontade é incondicionalmente livre. Para Isaiah Berlin, a busca por uma liberdade racional pressupõe um monismo moral que, como ele habilmente demonstra, esmaga a liberdade de escolha, tornando-a sem sentido. Nada mais contrário aos anseios liberais. Daí a defesa que Berlin faz do pluralismo moral - uma espécie de relativismo mais brando, caracterizado pela possibilidade de diálogo entre as culturas. Como vimos, para esse autor, o pluralismo moral importa a valorização da liberdade de escolha, porque aceita a possibilidade de valores últimos incompatíveis. 
Também nesse capítulo, analisamos brevemente o modo como o normativismo de Bobbio está ligado à defesa da liberdade. E vimos que, ao dar ênfase, em sua teoria, às normas de estrutura, Bobbio contribuiu para indicar uma das conclusões alcançadas neste trabalho: que a importância da regra da maioria decorre, também, do serviço que ela presta a alguns valores liberais.

As lições de Berlin, no segundo capítulo, anunciaram uma suposição extremamente relevante quanto ao binômio liberdade/democracia: que o convívio entre essas duas ideias era permanentemente ameaçado pelo racionalismo subjacente à liberdade democrática, o qual se mostrou historicamente hostil à liberdade de escolha. Assim, se as controversas relações entre liberdade e democracia motivaram a redação do segundo capítulo, ao terceiro capítulo coube uma exposição acerca do difícil convívio entre liberdade e razão.

Principiando pela tese de Ian Shapiro sobre a centralidade da razão e da liberdade no pensamento iluminista, observamos, no terceiro capítulo, a dificuldade que, de um modo geral, as correntes filosóficas influenciadas pelo Iluminismo encontraram para conciliar aqueles dois valores centrais. Observamos o acerto de Shapiro ao descrever John Stuart Mill como um pensador influenciado pelo Iluminismo e ao concluir que Mill também enfrentava aquela dificuldade. Com efeito, vimos que Mill enfrentou problemas para harmonizar a defesa quase incondicional da liberdade individual com sua convicção utilitarista quanto à possibilidade de encontrar as respostas certas a respeito da justiça.

Por outro lado, após discorrermos sobre as principais características do utilitarismo, passamos a examinar o princípio do dano e seu papel no âmbito do utilitarismo milliano. Nessa toada, expusemos as interpretações que alguns autores contemporâneos deram ao princípio do dano, discutimos as dificuldades de aplicação desse princípio e sua funcionalidade como critério para legitimação estatal. Em seguida, foi a vez de refletirmos sobre a tradição democrática e sobre a inclinação de Stuart Mill pela democracia representativa. Houve, pois, a oportunidade de se avaliar a defesa utilitarista das decisões majoritárias e o modo como John Stuart Mill buscou conciliar seu utilitarismo com o apoio ao governo popular. No final desse terceiro capítulo, abriu-se espaço para, finalmente, indagarmos a respeito das pretensões de John Stuart Mill no tocante ao princípio do dano. Procurou-se, então, responder à pergunta central desta pesquisa, atinente ao modo como o princípio do dano poderia servir de critério para limitar-se a regra da 
maioria. Nessa parte, portanto, ficaram consignadas as principais conclusões desta dissertação, em especial aquela segundo a qual a intenção de Mill foi a de estabelecer um princípio que instruísse os cidadãos. Além disso, salientou-se, naquela oportunidade, a conexão existente entre algumas ideias centrais do pensamento milliano e alguns argumentos que sustentam a importância do princípio majoritário como procedimento decisório respeitoso e equânime.

Por essa razão, o quarto capítulo da presente dissertação foi reservado para uma análise dos principais argumentos historicamente usados em defesa da aplicação das decisões majoritárias. Com Bobbio, vimos a diferença entre argumentos axiológicos e técnicos e observamos como estes pareciam, a princípio, mais convincentes na justificação do princípio majoritário. Na sequência, examinamos os argumentos de Jeremy Waldron.

Vimos que, segundo Waldron, a importância das decisões majoritárias é justificada por sua aptidão em produzir decisões coletivas de um modo respeitoso em relação à ampla variedade de opiniões existentes no seio da sociedade. Para desenvolver essa tese, Waldron postulou que o desacordo é uma característica persistente das sociedades - é uma condição elementar da política - e que nenhuma teoria política logrará sucesso se desprezar esse fato. De um modo geral, a tese de Waldron nos mostra que a regra da maioria respeita os desacordos, porque não exige o consenso: em seu mecanismo, parece estar implícito o reconhecimento da falibilidade humana. Essa é a chave para sua ligação com o liberalismo de John Stuart Mill.

Ao longo destes escritos, observamos que a visão falibilista do conhecimento humano é um dado importante no pensamento de Stuart Mill. E o falibilismo explica o fato dos desacordos, afinal, é precisamente por sua incapacidade de chegar a conclusões infalíveis sobre as questões de justiça que os homens resistem a concordar quanto a essas questões. O relevante papel da regra da maioria está em permitir que, a despeito da falibilidade humana e dos decorrentes desacordos, decisões coletivas sejam tomadas. E, conforme vimos, ela o faz de uma maneira que parece torná-la mais valiosa do que outros procedimentos. Tais argumentos, foi preciso reconhecer, retiram muito da força das acusações dirigidas ao princípio majoritário, quanto à arbitrariedade e à propensão ao despotismo majoritário. 
Na verdade, ao contrário do que nos faz supor as ponderações de Stuart Mill sobre a tirania da maioria, as principais ideias desse autor, presentes em A liberdade, nos permitem dizer que tal obra serve como sólido substrato para uma defesa das decisões majoritárias.

Que nos seja permitido finalizar com uma nota pessoal. Há mais de três anos, elaborei um trabalho para a conclusão de minha graduação nesta universidade. À maneira dos que buscam despedir-se em grande estilo, encerrei-o com uma frase de efeito, bastante adequada ao propósito a que o trabalho serviu e que era o de discutir a doutrina ética de um autor contemporâneo. A frase, que expressava uma convicção pessoal, dizia: "Não há genuína luta pela justiça que não seja precedida de uma humilde busca pela verdade". Com a presente dissertação, que ora entrego para o devido julgamento, creio ter aprendido a resignação de não esperar cegamente por essa suspeita dádiva a que chamam verdade. 


\section{REFERÊNCIAS BIBLIOGRÁFICAS}

ARENDT, Hannah. “Que é a liberdade?”. In: Entre o passado e o futuro. Traduzido por Mauro W. Barbosa de Almeida. 2. ed. São Paulo: Editora Perspectiva, 1972, pp. 188-220.

. "Verdade e política". In: Entre o passado e o futuro. Traduzido por Mauro W. Barbosa de Almeida. 2. ed. São Paulo: Editora Perspectiva, 1972, pp. 282-325.

. A condição humana. Traduzido por Roberto Raposo. 10. ed. Rio de Janeiro: Forense Universitária, 2009.

. A vida do espírito: o pensar, o querer, o julgar. Traduzido por Antonio Abranches e Helena Franco Martins. 2. ed. Rio de Janeiro: Civilização Brasileira, 2010.

e Ática, 1988.

Da Revolução. Traduzido por Fernando Dídimo Vieira. Rio de Janeiro: Ed. UNB

ARISTÓTELES. A Política. Traduzido por Roberto Leal Ferreira. 2. ed. São Paulo: Martins Fontes, 1998 (Clássicos).

ASCENÇÃO, José de Oliveira. O direito - introdução e teoria geral. 3. ed. Lisboa: Fundação Calouste Gulbenkian, 1982.

BENTHAM, Jeremy. Uma introdução aos princípios da moral e da legislação. In: MORRIS, Clarence. Os grandes filósofos do direito: leituras escolhidas. Traduzido por Reinaldo Guarany. São Paulo: Ed. Martins Fontes, 2002, pp. 261-273.

BERLIN, Isaiah. "Introdução". In: Quatro ensaios sobre a liberdade. Traduzido por Wamberto Hudson Ferreira. Brasília: Editora Universidade de Brasília, 1981 (Coleção Pensamento Político, $\left.n^{\circ} 39\right)$, pp. 01-41.

. Estudos sobre a humanidade: uma antologia de ensaios. Traduzido por Rosana Eichenberg; edição de Henry Hardy e Roger Hausheer. São Paulo: Companhia das Letras, 2002 .

BÍBLIA de Jerusalém. São Paulo, Ed. Paulus, 2002 (3ª impressão, 2004).

BOBBIO, Norberto. Elogio da serenidade e outros escritos morais. Traduzido por Marco Aurélio Nogueira. São Paulo: Editora UNESP, 2002.

. Liberalismo e democracia. Tradução de Marco Aurélio Nogueira. 6. ed. São Paulo: Brasiliense, 2006.

. Qual socialismo? - Debate sobre uma alternativa. Tradução de Iza de Salles Freaza. Rio de Janeiro: Paz e Terra, 1983 (Coleção Pensamento Crítico, v. 52).

Teoria do ordenamento jurídico. Tradução de Maria Celeste Cordeiro dos Santos. 10. ed. Brasília: Editora Universidade de Brasília, 1999. 
Teoria geral da política: a filosofia e as lições dos clássicos. Organizado por Michelângelo Bovero; traduzido por Daniela Beccaccia Versiani. 2. ed. Rio de Janeiro: Ed. Campus, 2000.

BORGES, Jorge Luis. “1982”. In: Os conjurados. Traduzido por Pepe Escobar. São Paulo: Editora Três, 1985.

CAMPILONGO, Celso Fernandes. Direito e Democracia. 2. ed. Editora Max Limonad, 2000.

CONSTANT, Benjamin. "Da liberdade dos antigos comparada à dos modernos". Traduzido por Loura Silveira. In: Revista Filosofia Política, $\mathrm{n}^{\circ}$ 2, 1985, pp. 01-07. Disponível em <http:/www.fflch.usp.br/dh/heros/antigosmodernos/seculoxix/constant/ liberdadeantigos.html $>$. Acesso em: 17/03/2011.

DAHL, Robert. Um prefácio à democracia econômica. Traduzido por Ruy Jungmann. Rio de Janeiro: Jorge Zahar Editor Ltda., 1990.

DINIZ, Maria Helena. Curso de direito civil brasileiro, $5^{\mathrm{o}}$ volume: direito de família. 20. ed. São Paulo: Saraiva, 2005.

DWORKIN, Gerald. "Paternalism". In: SCHAUER, Frederick e SINNOTTARMSTRONG, Walter (organizadores). The philosophy of law: classic and contemporary readings with commentary. New York: Oxford University Press, 1996, pp. 331-337.

DWORKIN, Ronald. "The Moral Reading and the Majoritarian Premise". In: KOH, Harold H. e SLYE, Ronald C. (organizadores). Deliberative democracy and human rights. New Haven e Londres: Yale University Press, 1999, pp. 81-115.

FEINBERG, Joel. Filosofia social. Traduzido por Alzira Soares da Rocha e Helena Maria Camacho. Rio de Janeiro: Zahar Editores, 1974.

. The moral limits of the criminal law. $3^{\circ}$ vol. - Harm to self. New York: Oxford University Press, 1986.

FERRAZ JUNIOR, Tercio Sampaio. Estudos de filosofia do direito: reflexões sobre o poder, a liberdade, a justiça e o direito. 2. ed. São Paulo: Editora Atlas, 2003.

. Introdução ao estudo do direito: técnica, decisão, dominação. 4. ed. São Paulo: Editora Atlas, 2003.

GILSON, Étienne. O espírito da filosofia medieval. Traduzido por Eduardo Brandão. São Paulo: Martins Fontes, 2006.

GRAY, John. Mill on liberty: a defense. 2. ed. London: Routledge, 1996.

GUISÁN, Esperanza. "Esperando por Mill". Traduzido por Rita de Cássia Lana. In: PELUSO, Luis Alberto (org.). Ética e utilitarismo. Campinas: Editora Alínea, 1998, pp. 111-130. 
GUISÁN, Esperanza. "Utilitarismo, justiça e felicidade". Traduzido por Edison Pereira da Silva. In: PELUSO, Luis Alberto (org.). Ética e utilitarismo. Campinas: Editora Alínea, 1998, pp. 131-141.

HARSANYI, John C.. "Rule Utilitarianism and Decision Theory". In: Erkenntnis (1975-), Vol. 11, n. 1, Social Ethics, Part 1, 1977, pp. 25-53. Disponível em: $<$ http://www.jstor/stable/20010532>. Acesso em: 17/03/2011.

HART, Herbert L. A.. O conceito de direito. Traduzido por Antonio de Oliveira SetteCâmara; pós-escrito e organizado por Penelope A. Bulloch e Joseph Raz. São Paulo: Editora WMF Martins Fontes, 2009.

HOBBES, Thomas. Leviatã ou Matéria, forma e poder de um estado eclesiástico e civil. Organizado por Richard Tuck; traduzido por João Paulo Monteiro e Maria Beatriz Nizza da Silva; tradução revisada por Eunice Ostrensky. São Paulo: Martins Fontes, 2008 (Clássicos Cambridge de filosofia política).

ISRAEL, Jonathan I.. Iluminismo Radical: a filosofia e a construção da modernidade, 1650-1750. Traduzido por Claudio Blanc. São Paulo: Madras, 2009.

KELSEN, Hans. A democracia. Traduzido por Ivone Castilho Benedetti, Jefferson Luiz Camargo e Marcelo Brandão Cipolla. São Paulo: Martins Fontes, 2000.

KELSEN, Hans. Teoria Pura do Direito. Traduzido por João Baptista Machado. 7. ed. São Paulo: Martins Fontes, 2006.

LAFER, Celso. "Filosofia do direito e filosofia política - notas sobre a defesa da liberdade no percurso intelectual de Norberto Bobbio". In: Ensaios sobre a liberdade. São Paulo: Ed. Perspectiva, 1980.

. "O moderno e o antigo conceito de liberdade". In: Ensaios sobre a liberdade. São Paulo: Ed. Perspectiva, 1980.

. A reconstrução dos direitos humanos - Um diálogo com o pensamento de Hannah

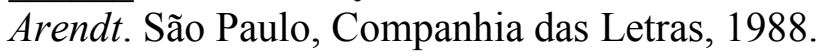

Ensaios Liberais. São Paulo: Siciliano, 1991.

1988.

Hannah Arendt: pensamento, persuasão e poder. 2. ed. São Paulo: Paz e Terra,

LECLERCQ, Claude. Le principe de la majorité. Paris: Librairie Armand Colin, 1971.

LEVI, Lucio. "Legitimidade". In: BOBBIO, Norberto; MATTEUCCI, Nicola; PASQUINO, Gianfranco. Dicionário de política - Vol. 2. Traduzido por Carmen C. Varriale et. al. 12. ed. Brasília: UNB, 2004, pp. 675-679.

LOCKE, John. Dois Tratados sobre o Governo. Traduzido por Julio Fischer; rev. técnica de Renato Janine Ribeiro. São Paulo: Martins Fontes, 2005. 
MACHADO, Nilson José. "A maioria tem sempre razão. Ou não.", in Revista USP, São Paulo, ${ }^{\circ}$ 55, pp. 271-285, setembro/dezembro 2005.

MAIMON, Moisés Bem. O livro dos mandamentos: 248 preceitos positivos. Traduzido por Giuseppe Nahaïssi. São Paulo: Hedra, 2007.

MARQUES, João Batista. "O princípio de maioria na doutrina de Hans Kelsen", in Revista de Informação Legislativa, Brasília, vol. 42, n 165, pp. 51-58, janeiro/março 2005.

MATTEUCCI, Nicola. "Paternalismo". In: BOBBIO, Norberto; MATTEUCCI, Nicola; PASQUINO, Gianfranco. Dicionário de política - Vol. 2. Traduzido por Carmen C. Varriale et. al. 12. ed. Brasília: UNB, 2004, pp. 908-909.

MENDES, Conrado Hübner. Controle de Constitucionalidade e Democracia. Rio de Janeiro: Elsevier, 2008.

MERQUIOR, José Guilherme. O liberalismo - antigo e moderno. Traduzido por Henrique de Araújo Mesquita. 2. Ed. Rio de Janeiro: Ed. Nova Fronteira, 1991.

MILL, John Stuart. "Chapter XXVI: On Freedom of the Will”. In: The collected works of John Stuart Mill, Volume IX - An examination of Willian Hamilton's philosophy. Londres: Routledge and Kegan Paul, 1979, pp. 14-15. Disponível em:

http://oll.libertyfund.org/?option=com_staticxt\&staticfile=show.php\%3Ftitle=240\&chapter $=40902 \&$ layout $=$ html\&Itemid=27 $>$. Acesso em: 17/03/2011. Fontes, 2000.

A liberdade / Utilitarismo. Traduzido por Eunice Ostrensky. São Paulo: Martins . Considerações sobre o governo representativo. Traduzido por Jacy Monteiro. São Paulo: Ibrasa, 1964.

Sons Ltd., 1910.

Utilitarianism, Liberty and Representative Government. Londres: J. M. Dent \&

MONTESQUIEU, Baron Charles de Secondat. O espírito das leis. In: MORRIS, Clarence. Os grandes filósofos do direito: leituras escolhidas. Traduzido por Reinaldo Guarany. São Paulo: Ed. Martins Fontes, 2002, pp. 158-181.

NOVAIS, Jorge Reis. Direitos fundamentais: trunfos contra a maioria. Coimbra: Coimbra Editora, 2006.

OFFE, Claus. "Legitimação política por decisão majoritária?". In: Problemas estruturais do Estado capitalista. Traduzido por Barbara Fraitag. Rio de Janeiro: Ed. Tempo Brasileiro, 1984.

RAWLS, John. Uma teoria da justiça. Traduzido por Almiro Pisetta e Lenita M. R. Esteves. São Paulo: Martins Fontes, 1997.

REALE, Miguel. Horizontes do direito e da história. 3. ed. São Paulo: Saraiva, 2000. 
ROSEN, Fred. "Liberdade constitucional e democracia representativa". Traduzido por C. Cintra. In: PELUSO, Luis Alberto (org.). Ética e utilitarismo. Campinas: Editora Alínea, 1998, pp. 49-62.

ROSS, Alf. Direito e Justiça. Trad. ao português, a partir da versão inglesa, por Edson Bini. Bauru, SP: EDIPRO, 2000.

ROUSSEAU, Jean-Jacques. Do contrato social: princípios de direito político. Traduzido por José Cretella Jr. e Agnes Cretella. 2. ed. São Paulo: Editora Revista dos Tribunais, 2008.

RUFFINI, Edoardo. Il principio maggioritario: profilo storico. Milão: Adelphi Edizioni S.P.A., 1976.

RYAN, Alan. "Mill in a liberal landscape". In: SKORUPSKI, John (organizador). The Cambridge companion to Mill. Nova York: Cambridge University Press, 1998, pp. 497537.

SABINE, George Holland. História das ideias políticas - Vol. 2. Traduzido por Ruy Jungmann. Rio de Janeiro: Fundo de Cultura, 1964.

SALAMUN, Kurt. "Karl R. Popper - Etos iluminista e racionalidade crítica". In: HENNIGFELD, Jochem e JANSOHN, Heinz (organizadores). Filósofos da atualidade. Traduzido por Ilson Kayser. São Leopoldo - RS: Editora Unisinos, 2006, pp. 66-92.

SANTO AGOSTINHO. Confissões. Traduzido por Oliveira Santos, S.J. e A. Ambrósio de Pina, S.J.. São Paulo: Editora Nova Cultural, 1999.

SHAPIRO, Ian. Os fundamentos morais da politica. Traduzido por Fernando Santos. São Paulo: Martins Fontes, 2006.

SINGER, Peter. Ética Prática. Traduzido por Jeferson Luiz Camargo. 3. ed. São Paulo: Martins Fontes, 2002.

SPITZ, Elaine. Majority rule. Chatham: Chatham House Publishers, 1984.

TAYLOR, Charles. As fontes do self - A construção da identidade moderna. Traduzido por Adail Ubirajara Sobral e Dinah de Abreu Azevedo. São Paulo: Edições Loyola, 1997.

TOCQUEVILlE, Alexis de. A Democracia na América. Traduzido por Neil Ribeiro da Silva. Belo Horizonte: Editora Itatiaia; São Paulo: Edusp, 1987.

VENOSA, Silvio de Salvo. Código Civil interpretado. São Paulo: Atlas, 2010.

VOLPE, Galvano Della. "Il problema della libertà egualitaria nello svilupo della Moderna Democrazia”. In: D’ENTRÈVES, Alessandro Passérin (organizador). La libertà politica. Edizioni di Comunità, 1974, pp. 55-66. 
WALDRON, Jeremy. A Dignidade da Legislação. Traduzido por Luís Carlos Borges. São Paulo: Martins Fontes, 2003.

. "Deliberation, Disagreement, and Voting". In: KOH, Harold H. e SLYE, Ronald C. (organizadores). Deliberative democracy and human rights. New Haven e Londres: Yale University Press, 1999, pp. 210-226.

"Mill and the Value of Moral Distress". In: Political Studies. Volume XXXV, n 03: Political Studies Association, 1987, pp. 410-423.

Derecho y desacuerdos. Traduzido ao espanhol por José Luis Marti e Águeda Quiroga. Madrid: Marcial Pons Ediciones Jurídicas y Sociales, 2005.

WALZER, Michael. Da Tolerância. Traduzido por Almiro Pisetta. São Paulo: Martins Fontes, 1999.

Esferas da Justiça: uma defesa do pluralismo e da igualdade. Traduzido por Jussara Simões. São Paulo: Martins Fontes, 2003. 